$$
\begin{gathered}
\text { UNIVERSIDADE DE SÃO PAULO } \\
\text { ESCOLA DE ENGENHARIA DE SÃO CARLOS } \\
\text { DEPARTAMENTO DE ENGENHARIA DE PRODUÇÃO }
\end{gathered}
$$

Governança Corporativa e Restrição Financeira nas Decisões de Investimento 


\section{Governança Corporativa e Restrição Financeira nas Decisões de} Investimento

Dissertação apresentada ao Departamento de Engenharia de Produção da Escola de Engenharia de São Carlos da Universidade de São Paulo como requisito para obtenção do título de Mestre em Ciências.

Área de Concentração: Economia, Organizações e Gestão do Conhecimento.

Orientador: Prof. Associado Aquiles Elie Guimarães Kalatzis

São Carlos 
AUTORIZO A REPRODUÇÄO E DIVULGAÇÃO TOTAL OU PARCIAL DESTE TRABALHO, POR QUALQUER MEIO CONVENCIONAL OU ELETRÓNICO. PARA FINS DE ESTUDO E PESQUISA, DESDE QUE CITADA A FONTE.

Ficha catalográfica preparada pela Seçäo de Tratamento da Informação do Serviço de Bblioteca - 巴SSCIUSP

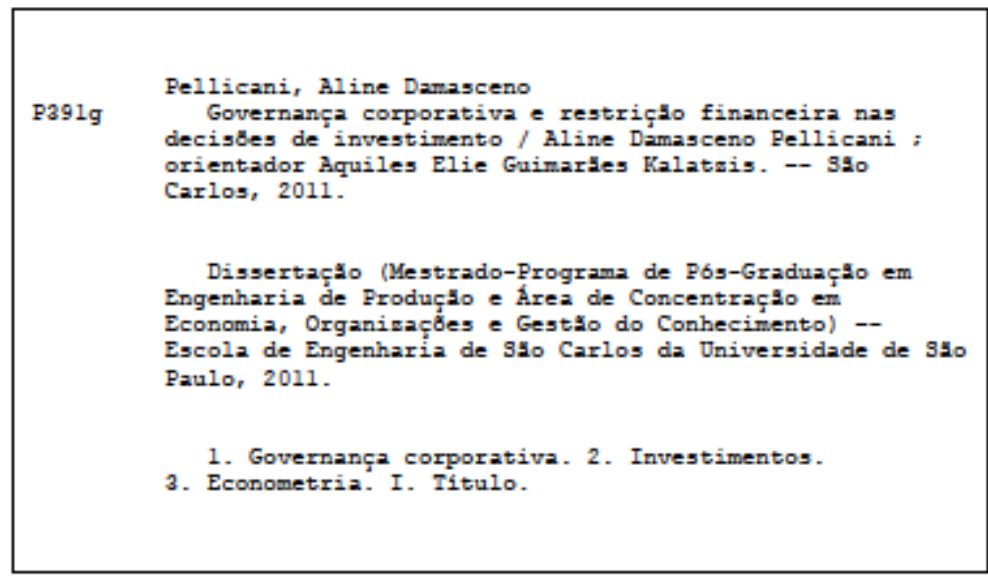


FOLHA DE JUGAMENTO

Candidato(a): Licenciada ALINE DAMASCENO PELLICANI.

Dissertação defendida e julgada em 17.02.2011 perante a Comissăo Julgadora:

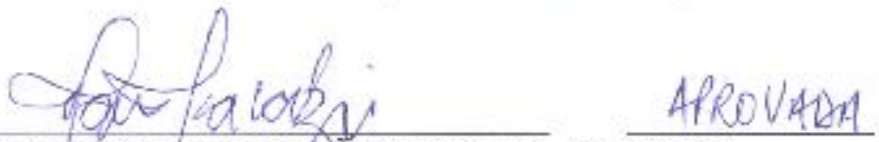

Prof. Assiuciado AQUíLís ELIE GUIMABÄES KALA TZIS - (Orientador)

(Lscola de Engenhariá de São CarlositUSP)

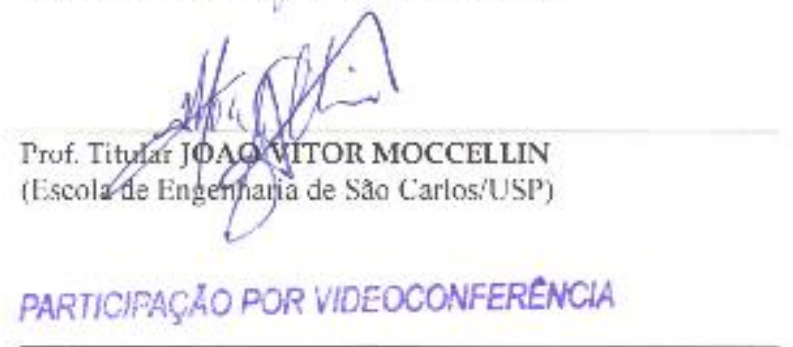

APROPAOA

Prof. Dr, DANTE MENDES ALDRIGHI

(Faculdade de Economia, Administração e Contabilidade'USP)

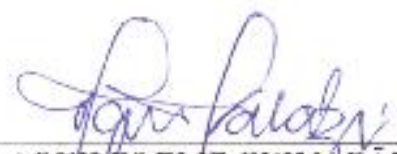

Prof. Associado AQIML tes ELIE GLIMARÁRES KALATZIS

Coordenador do Programa de Pós-Graduação $\mathrm{cm}$

Fngenharia de Produçãăo

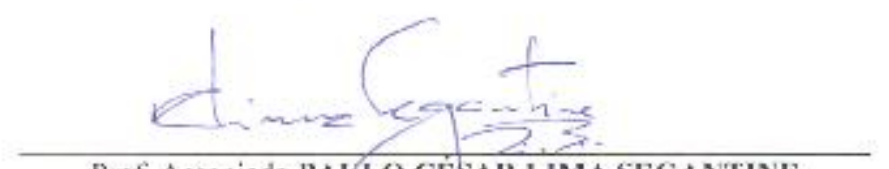

Prof. Associado PACLO CÉSAR LIMA SEGANTINE

Presidente da Corpissão da Pós-Ciraduaçāio da FESC: 
Aos meus pais, irmãos $e$ Leonardo. 


\section{Agradecimentos}

Ao Prof. Assoc. Aquiles Elie Guimarães Kalatzis pela paciência, orientação e incontáveis vezes que me atendeu, mostrando-se sempre disposto a debater os problemas e dúvidas em torno deste trabalho. Agradeço também as horas do café!

Ao Prof. Tit. João Vitor Moccelin e Prof. Dr. Dante Mendes Aldrighi pelas participações na banca de qualificação e de defesa, além das sugestões propostas.

Ao Departamento de Engenharia de Produção da Escola de Engenharia de São Carlos e todos seus funcionários, em especial, a Claudete, que deu suporte e auxilio nas questões administrativas.

À Coordenação de Aperfeiçoamento de Pessoal de Nível Superior - CAPES.

Agradeço também a amiga Fernanda, pelas incontáveis vezes que a telefonei pedindo ajuda, sempre disposta a colaborar e contribuir no que fosse possível para a melhor elaboração deste trabalho. Aos colegas de laboratório: Lucília, Marina, Flávio e Camila, e em especial a amiga Rayani, pelos bons papos e cafés, e principalmente, pela ajuda na montagem e coleta final do banco de dados.

À todos os meus amigos de São Carlos e Ribeirão Preto, em especial, aos meus amigos Steve, Maria Clara e Carolina, pelo carinho, amizade e por me ouvirem e compartilharem os momentos difíceis e os felizes.

Ao Leonardo Cusumano, meu namorado, amigo e companheiro, sempre ao meu lado me ouvindo, apoiando, incentivando e sempre disposto a fazer o que fosse possível para me ver sempre feliz!

E, principalmente, à Deus, meus pais e meus irmãos, que são o meu apoio, suporte, sinônimo de amor e felicidade e representam tudo o que sou hoje! 


\section{RESUMO}

PELliCANI, A. D., Governança Corporativa e Restrição Financeira nas Decisões de Investimento, 110 p., Dissertação (mestrado) - Escola de Engenharia de São Carlos, Universidade de São Paulo, São Carlos, 2011.

O presente trabalho tem por objetivo analisar a relação entre aspectos de governança corporativa e restrição financeira nas decisões de investimento de 500 firmas brasileiras de capital aberto no período de 1997 a 2007. Embora exista uma extensa literatura a respeito da decisão de investimento na presença da restrição financeira, estudos que relacionam este tema com aspectos de governança corporativa são ainda pouco explorados e inexistentes na literatura brasileira. Para examinar como os mecanismos de governança corporativa influenciam no grau de restrição financeira das firmas, utilizou-se do modelo probabilístico logit para dados em painel, estimado por efeito aleatório $\mathrm{O}$ relacionamento dos mecanismos de governança corporativa com a decisão de investimento das firmas na presença de restrição financeira foi analisado por meio de uma versão modificada do modelo acelerador do investimento, considerando três agrupamentos: índice KZ, tamanho das firmas e pagamento de dividendos. Na estimação, utilizou-se o método dos momentos generalizados (GMM) para considerar o aspecto dinâmico e corrigir o problema da endogeneidade do modelo. A análise da amostra indicou uma alta incidência da propriedade concentrada das firmas brasileiras, principalmente entre as firmas com natureza familiar. Os resultados mostraram que firmas com qualquer natureza de propriedade e controle elevam a sua probabilidade de restrição financeira quando o maior acionista último é o acionista controlador da firma, muito embora, a natureza do acionista controlador impacte a taxa de investimento das firmas de maneiras distintas. Firmas com estrutura de propriedade piramidal elevam sua probabilidade de restrição financeira. Este resultado combinado com a estimação do modelo de investimento evidencia que apenas pertencer a uma estrutura de propriedade piramidal não é suficiente para que haja transferência de recursos que aumentem os investimentos das firmas. O impacto da inserção da firma a um dos níveis diferenciados de governança corporativa da BM\&FBOVESPA ou ao Novo Mercado sobre a taxa de investimento está relacionado com a situação financeira da firma. $\mathrm{O}$ aumento nos direitos de fluxo de caixa dos maiores acionistas últimos contribui para reduzir a sensibilidade do investimento ao fluxo de caixa, sendo que, o mesmo não foi observado para o aumento nos seus direitos de voto.

Palavras-chave: Governança Corporativa, Restrição Financeira, Decisão de Investimento, Estrutura de Propriedade e Controle. 


\begin{abstract}
PELLICANI, A. D., Corporate Governance and Financial Constraint on Investment Decisions, 110 p., Dissertation (master's degree) - School of Engineering of São Carlos, University of São Paulo, São Carlos, 2011.
\end{abstract}

This study aims to investigate the relationship between aspects of corporate governance and financial constraints on investment decisions of 500 Brazilian public traded firms over the period of 1997-2007. Although studies of financial constraints and investment decisions are extensive in literature, its relationship with aspects of governance is little explored and inexistent for Brazilian economy. To examine how aspects of corporate governance influences the likelihood of firm's financial constraints, it was used the logit probabilistic model to panel data estimated by random effect. The relationship between corporate governance mechanisms and investment decisions on firm's financial constraints was analyzed by a modified version of accelerator investment model, considering three groups: KZ index, firm's size and dividends payout. In the estimation, it was used the generalized moments method (GMM) to consider the dynamic aspect and to correct the endogeneity problem in the model. The sample analysis indicated a high incidence of concentrated ownership among Brazilian firms, mainly in family firms. The results showed that firms with any type of ownership and control raises their likelihood of financial constraint when the largest ultimate shareholder is the controller of the firm, although the nature of the controlling shareholder impacts investment rate of firms in different ways. Pyramidal ownership firms also raise the likelihood of financial constraint. This result combined to results of investment model evidences that only belong to pyramidal ownership structure is not sufficient to have transfer of resources that raises the firm's investment rate. The impact of the association of firm's to BM\&FBOVESPA differential levels of corporate governance or to Novo Mercado on investment rate is related to financial status of the firm. The increase in cash flow rights of the largest ultimate shareholder contributes to reduce investment-cash flow sensitivity, however, the same was not observed to the increase in voting rights.

Keywords: Corporate Governance, Financial Constraint, Investment Decision, Ownership Structure and Control. 


\section{LISTA DE FIGURAS}

Figura 1: Esquema de Propriedade Piramidal da Grendene S.A ........................................... 22 


\section{LISTA DE TABELAS}

Tabela 1: Características das firmas - Estatísticas Descritivas

Tabela 3: Participação do Maior Acionista Último- Estatísticas Descritivas

Tabela 4: Participação do maior acionista último $\times$ natureza do acionista controlador 76

Tabela 5: Níveis de Governança Corporativa - Estatística Descritiva 77

Tabela 7: Estimação GMM - Índice KZ 81

Tabela 8: Estatísticas Descritivas - Pagamento de Dividendos e Tamanho 86

Tabela 9: Estimação GMM - Pagamento de Dividendos e Tamanho da Firma 89

Tabela A.1: Tabela de Correlação entre as variáveis utilizadas no estudo. 112 


\section{LISTA DE QUADROS}

Quadro 1: Modelo geral de governança corporativa brasileiro 31

Quadro 2: Principais exigências: Nível 1, Nível 2 e Novo Mercado 37

Quadro 3: Exigências do Bovespa Mais 38

Quadro A.1: Definição das variáveis de Governança Corporativa 109

Quadro A.2: Definição das variáveis financeiras 111 


\section{LISTA DE ABREVIATURAS E SIGLAS}

BM\&BOVESPA: Bolsa de Valores, Mercadorias e Futuros de São Paulo

BNDES: Banco Nacional de Desenvolvimento Econômico e Social.

CVM: Comissão de Valores Mobiliários

DFP: Demonstrações Financeiras Padronizadas

IAN: Informativo Anual

IBGC: Instituto Brasileiro de Governança Corporativa

GMM: Método dos Momentos Generalizados

ON: Ações Ordinárias

PN: Ações Preferenciais

S.A.: Sociedade Anônima 


\section{SUMÁRIO}

1. INTRODUÇÃO..

2. GOVERNANÇA CORPORATIVA

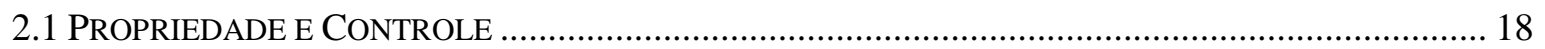

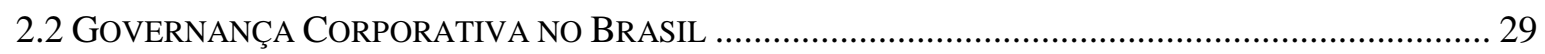

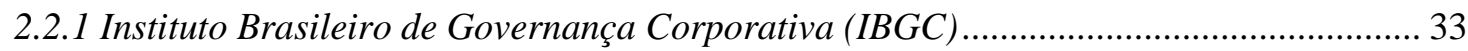

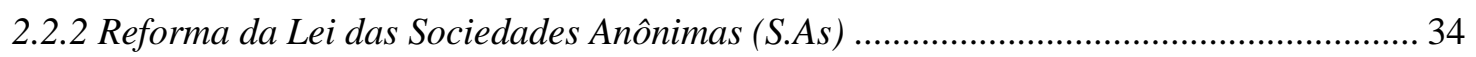

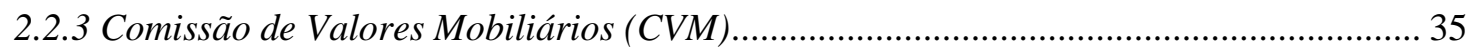

2.2.4 Bolsa de Valores, Mercadorias e Futuros (BM\&FBOVESPA) ......................................... 35

2.2.5 Banco Nacional de Desenvolvimento Econômico e Social (BNDES).............................. 38

\section{ASPECTOS DE GOVERNANÇA CORPORATIVA E RESTRIÇÃO FINANCEIRA}

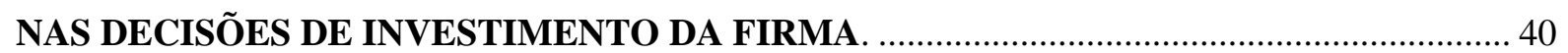

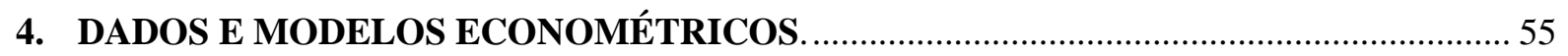

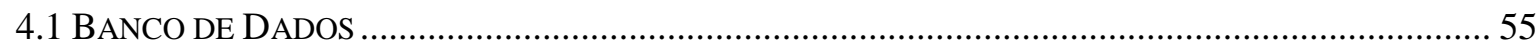

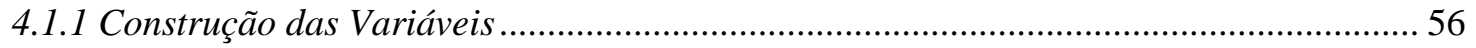

4.2 Modelos ECONOMÉTRICOS PARA DADOS EM PAINEL ............................................................ 59

5. DECISÕES DE INVESTIMENTO E RESTRIÇÃO FINANCEIRA: A INFLUÊNCIA

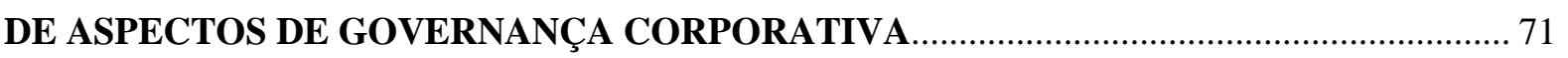

5.1 GovernanÇa Corporativa, Pagamento de Dividendos E TAMANHO DA FIRMA. ............ 85

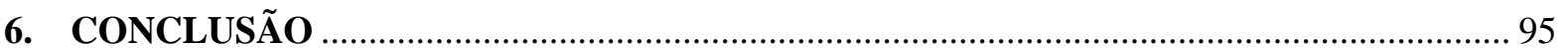

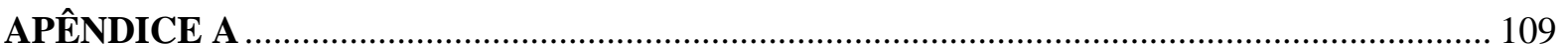




\section{Introdução}

Após escândalos financeiros que comprometeram o relacionamento entre firmas e acionistas, os investidores iniciaram um movimento para a instituição de mecanismos que os protegessem ativamente contra o detrimento de seus interesses por parte dos gestores. Esse movimento originou o termo "Governança Corporativa" que surgiu para superar o conflito de agência entre gestores e acionistas e impor mecanismos que os protegessem contra uma potencial expropriação de seus recursos pelos gestores. Entre os mecanismos instituídos pela governança corporativa estão a proteção dos direitos dos acionistas, igualdade entre majoritários e minoritários, qualidade das informações contábeis e financeiras, transparência na divulgação de informações e a ética nas corporações.

Também preocupados com o impacto que estes escândalos financeiros causaram na economia dos países, os governos intensificaram a regulamentação do mercado de capitais para fortalecer os ideais dos investidores e criar um ambiente seguro para as realizações de operações no mercado. Dentre as medidas adotadas pelo governo brasileiro para incentivar a adoção de boas práticas de governança corporativa, pode-se citar: a reformulação da Lei das S.As em 2001; reestruturação da CVM; Níveis Diferenciados de Governança Corporativa e Novo Mercado criados pela BM\&FBOVESPA em 2000; alterações das normas de regulamentação sobre a atuação dos fundos de pensão e investimento; e, a reforma da lei de falência em 2005.

Ainda com o intuito de acelerar e incentivar o fortalecimento do mercado de capital, além de torná-lo mais acessível às firmas, a BM\&FBOVESPA criou em 2008, o Bovespa Mais ${ }^{1}$, que se estrutura como um novo segmento de listagem na bolsa de valores. O objetivo do Bovespa Mais é incentivar a abertura de capital de firmas de pequeno e médio porte em fase de crescimento e ampliação de liquidez, mas que ainda não são capazes de aderir a um dos níveis diferenciados de governança corporativa e Novo Mercado. Com a inclusão deste novo segmento, a BM\&FBOVESPA prevê a abertura do capital de mais de 200 firmas até o ano de 2015.

No entanto, mesmo com todos os esforços para a consolidação do mercado de capitais como uma forte ferramenta de aquisição de recursos para a realização de investimentos, as firmas ainda encontram barreiras diante da presença de imperfeições naturais do mercado. Para ser inserida nos níveis diferenciados de governança corporativa,

\footnotetext{
${ }^{1}$ Bovespa "Mais" significa Bovespa "Mercado de Ações para Ingresso de S.As"
} 
Novo Mercado e Bovespa Mais, as firmas necessitam cumprir diversos compromissos com a BM\&FBOVESPA, tais como: transparência nas informações, concessão de ações com direito de voto, inserção de conselheiros independentes no conselho de administração, a manutenção de uma parcela mínima de ações em circulação que represente $25 \%$ do capital (free float), que dentre outras obrigações, ocasionam a redução do problema de assimetria de informação mas que, consequentemente, geram despesas adicionais às firmas. Dessa forma, pode ser que muitas firmas optem, em primeira instância, pela utilização de capitais próprios para a realização de seus investimentos, recorrendo a recursos de terceiros em um segundo momento, caso necessário. Com isso, a realização de investimentos e, por conseguinte, as oportunidades de desenvolvimento e crescimento da firma ficariam sujeitos à disponibilidade de seus fundos internos. Essa forte dependência por recursos próprios poderia ocasionar uma restrição a novos investimentos, visto que tais recursos são limitados.

Diversos estudos surgiram com o intuito de explicar o comportamento do investimento das firmas quando estas enfrentam restrições financeiras; no entanto, o interesse se intensificou com o estudo de Fazzari, Hubbard e Petersen (1988). Os autores consideraram uma variedade de argumentos para explicar porque o custo do financiamento externo diferia do financiamento interno. Adotando a disponibilidade de fundos internos, medido pelo fluxo de caixa, como uma proxy ${ }^{2}$ para problemas de assimetria de informação, os autores notaram que as firmas com baixo pagamento de dividendos dependeriam mais de seus fundos internos para a realização de seus investimentos, dada a significância e a relação positiva entre o fluxo de caixa e a taxa de investimento. No entanto, Kaplan e Zingales (1997) argumentaram que apenas a significância e o parâmetro positivo do fluxo de caixa não seriam suficientes para identificar a firma como restrita financeiramente, já que o parâmetro positivo também poderia ser um indicativo de potencial de rentabilidade futura.

Após estes estudos, muitos outros surgiram para investigar o papel da restrição financeira sobre as decisões de investimento das firmas. Critérios distintos têm sido utilizados na literatura para classificar as firmas em grupos, de tal forma que se possa diferenciar e identificar uma firma como restrita financeiramente. Além disso, muito se questiona sobre a forma de interpretar e definir o que seria a restrição financeira. A literatura proporciona várias definições, por exemplo, Kaplan e Zingales (1997) consideram uma firma como restrita financeiramente se os custos ou a disponibilidade de fundos externos a impedem de realizar

\footnotetext{
${ }^{2}$ Variável proxy é uma variável observada que é relacionada, mas não idêntica a uma variável explicativa não observada em análise na regressão (Wooldrigde, 2006).
} 
novos empreendimentos que teria escolhido se recursos internos estivessem disponíveis. Para Bond e Reenen (2003), uma firma é restrita financeiramente se um crescimento inesperado na disponibilidade de seus recursos internos provocar um aumento nos gastos com investimentos, sem que este aumento proporcione qualquer tipo de informação sobre o potencial de sua lucratividade futura. Já para Lamont, Polk Saá-Requejo (2001), restrição financeira é interpretada como os atritos que impedem a firma de realizar todos os investimentos por ela desejados. Essa incapacidade de conseguir investimento pode estar relacionada com a falta de crédito, com a dependência de empréstimos bancários ou com a falta de liquidez de ativos, dentre outras causas.

Apesar da ampla literatura sobre o comportamento das decisões de investimento na presença da restrição financeira, a discussão em torno deste tema continua intensa, não havendo uma conclusão definitiva a respeito do procedimento ideal para identificar uma firma como restrita financeiramente. Recentes estudos como os de Gugler (2003), Ginglinger e Saddour (2007) e Wei e Zhang (2008) tem incorporado características de governança corporativa para explicar o comportamento do investimento das firmas na presença da restrição financeira e como tais características poderiam contribuir para a diminuição das restrições de financiamento. No entanto, esta nova vertente da literatura do investimento é recente, sendo muito escassa internacionalmente e inexistente para a economia brasileira.

Diante deste fato, este estudo procura contribuir para essa literatura, analisando como algumas características de governança corporativa, como por exemplo: a natureza da estrutura de propriedade e controle, a existência de acionista controlador, a presença do maior acionista último como membro do conselho de administração e como diretor executivo da firma, e a adesão a um dos níveis diferenciados de governança corporativa poderiam amenizar a probabilidade de a firma ser considerada restrita financeiramente e influenciar nas decisões de investimento das firmas. Para que isso fosse possível, utilizou-se um banco de dados criado a partir de dados extraídos do relatório Informativo Anual (IAN), do Economatica e do site da BM\&FBOVESPA. Para incluir o maior número possível de informação, foi utilizado um painel não balanceado que totalizou 500 firmas brasileiras no período de 1997 a 2007.

As firmas foram agrupadas de acordo com o índice $\mathrm{KZ}$ entre firmas consideradas restritas e não restritas financeiramente, o que possibilitou a criação da variável binária $K Z$ que identifica as firmas consideradas restritas financeiramente. Essa variável possibilitou estimar um modelo probabilístico logit para dados em painel por efeito aleatório e, assim, identificar como alguns mecanismos de governança influenciam na probabilidade de restrição financeira. Para analisar o comportamento do investimento das firmas, um modelo de 
investimento foi estimado pelo Método dos Momentos Generalizados (GMM), considerandose três formas distintas de agrupamento: o índice KZ, tamanho e o pagamento de dividendos.

Para a realização do objetivo proposto, o presente trabalho está estruturado em seis capítulos, incluindo esta introdução. No capítulo 2 é realizada uma revisão de literatura sobre a governança corporativa, em um aspecto geral, e como é a sua estruturação no Brasil, destacando os incentivos governamentais e institucionais que visam o fortalecimento do mercado de capitais e a proteção dos acionistas.

No capítulo 3, desenvolve-se uma revisão de literatura sobre as decisões de investimento na presença da restrição financeira, ressaltando os debates em torno do agrupamento ideal, que possibilite identificar a presença da restrição financeira nas firmas, e da interpretação da sensibilidade do investimento ao fluxo de caixa. Neste capítulo também se inclui os recentes estudos que abordam características de governança corporativa para explicar o comportamento do investimento das firmas que enfrentam situações de restrição financeira.

No capítulo 4 é apresentado o banco de dados utilizado neste estudo, descrevendo a construção das variáveis de governança corporativa e das variáveis financeiras, além da construção do índice KZ, que é o principal constituinte deste estudo. Neste capítulo também é descrito os modelos econométricos utilizados e seus respectivos métodos de estimação.

No capítulo 5 realiza-se a análise e interpretação dos resultados. Em um primeiro momento, é feito uma investigação sobre o comportamento dos mecanismos de governança corporativa na probabilidade de restrição financeira das firmas, considerando como variável dependente, uma variável binária construída a partir do índice KZ. Com o propósito de investigar se os mecanismos de governança corporativa contribuem para explicar o comportamento do investimento das firmas que enfrentam situações de restrição financeira, a amostra foi divida de acordo com três agrupamentos: firmas restritas e não restritas financeiramente segundo o índice KZ, tamanho das firmas e pagamento de dividendos, e uma versão modificada do modelo acelerador do investimento foi estimada por meio do método dos momentos generalizados (GMM).

Por fim, no capítulo 6, conclui-se os principais resultados econômicos obtidos ao longo do trabalho. 


\section{Governança Corporativa}

A governança corporativa tem sido um tema de grandes debates tanto na comunidade acadêmica quanto nas políticas econômicas de diversos países. Por estar relacionada a teorias que são provenientes de fatores como finanças, economia, contabilidade, leis, comportamento organizacional e crises financeiras, a adoção de boas práticas de governança corporativa nas organizações tem sido incentivada pelo governo e por instituições com o intuito de beneficiar o mercado de capitais e estimular o crescimento da economia.

Considerando a importância do tema, este capítulo tem por objetivo discutir e explicar como o conceito de governança corporativa se desenvolveu, tomando por base, a separação entre propriedade e controle, além de apresentar os principais mecanismos internos e externos de governança, cujo propósito é o de garantir que as decisões tomadas pelas organizações visem à maximização dos retornos dos investimentos e os interesses dos acionistas.

Neste capítulo, também se discute como é a estrutura de governança corporativa no Brasil, considerando o desenvolvimento do mercado de capitais brasileiro, os tipos de ações comercializadas, ressaltando como os tipos de ações interferem na estrutura de propriedade e controle e nas práticas dos mecanismos de governança corporativa. Outro aspecto também considerado neste capítulo está relacionado com as principais contribuições governamentais e institucionais brasileiras que contribuem para o melhor comprometimento das práticas de governança corporativa, como as desenvolvidas pelo IBGC, BNDES e BM\&FBOVESPA.

\subsection{Propriedade e Controle}

A separação entre controle e propriedade é um tema de grande discussão na comunidade acadêmica. Com o crescimento da firma e sua necessidade de captação de recursos, um único proprietário ou uma família tornava-se incapaz de administrá-la e financiála, surgindo assim, a necessidade da abertura de capital e da disseminação da propriedade, como também, a procura por profissionais capacitados que pudessem melhorar a administração da firma. Esse processo de inserção de profissionais externos na gerência da firma origina o relacionamento de agência, definido por Jensen e Meckling (1976) como a situação em que uma ou mais pessoas (principal/acionistas) contratam uma outra pessoa (agente/gestor) para executar algum serviço que envolva a tomada de decisão em seus nomes.

Estudando as relações entre propriedade e controle de firmas norte-americanas, Berle 
e Means (1932) constataram que essa inserção de profissionais externos na administração permitia que as decisões sobre a alocação de recursos das firmas fossem tomadas sem a autorização prévia dos proprietários, o que permitiria aos gestores atuar em benefício próprio, visando apenas à maximização de seus interesses pessoais em detrimento dos interesses dos acionistas.

A possibilidade de expropriação de recursos dos proprietários por parte dos gestores ocasiona conflitos de interesse entre gestores e acionistas ${ }^{3}$. É devido a estes conflitos que surgem os problemas de agência. De acordo com Jensen e Meckling (1976), mesmo em posse de um contrato entre gestores e acionistas, ainda podem ocorrer situações em que os interesses e as motivações entre as partes sejam convergentes ou divergentes. Das divergências, surge a necessidade do principal garantir que seus interesses sejam realizados com segurança. Para isso, existe a necessidade de limitação e monitoramento das ações dos gestores e o estabelecimento de incentivos contratuais apropriados que inibam a possibilidade da não atuação dos gestores em benefício do principal. Entretanto, esse monitoramento para alinhar os interesses gera custos, denominados como "custos de agência".

Custos de agência são os custos necessários para a redução das assimetrias de informação entre gestores e acionistas ${ }^{4}$. Jensen e Meckling (1976) e Fama e Jensen (1983) os definem como a soma dos gastos de monitoramento das atividades dos gestores, dos custos da estruturação do contrato entre as partes envolvidas e da prestação de contas dos gestores para explicitar que seus gastos são benéficos para o principal e para a firma, além das perdas residuais advindas do conflito entre gestores e acionistas. Jensen e Meckling (1976) também afirmam que uma firma só terá custo de agência zero se ela possuir apenas um gestor que seja proprietário total da mesma, mas esse tipo de empresa não existe entre firmas de capital aberto, cujo maior proprietário possui menos de $100 \%$ do capital da firma ${ }^{5}$.

Entretanto, para evitar todos estes problemas advindos do relacionamento de agência, seria viável supor a existência de um contrato completo, como proposto por com Shleifer e Vishny (1997) em que todos os deveres dos gestores e a alocação dos fundos da firma fossem

\footnotetext{
${ }^{3}$ Tirole (2006) aponta como algumas das principais formas de expropriação de recursos dos acionistas: o risco moral em que os gestores empregam esforços insuficientes no controle interno da companhia, os investimentos extravagantes em projetos não lucrativos que causam pouco retorno aos investidores, self-dealing (ocorre quando gestores aumentam os benefícios privados oferecidos pela firma) e estratégias entrenchment (manobras realizadas por grandes executivos para assegurar sua posição na empresa desconsiderando o objetivo dos investidores. Nesse tipo de estratégia, gestores investem em suas linhas de pesquisa para se tornar indispensáveis e poderem manipular medidas de desempenho).

4 Assimetria de informação ocorre quando gestores possuem informações privilegiadas sobre o andamento administrativo e financeiro da firma que não são completamente repassadas aos agentes.

${ }^{5}$ Fato também constatado por Ang, Cole, Lin (2000) em uma amostra de 1708 firmas de pequeno porte.
} 
especificados. Contudo, em vista das incertezas futuras, existe a necessidade de concessão de direitos de controle residual aos gestores, ou seja, frente a circunstâncias inesperadas, gestores poderiam tomar decisões em nome dos acionistas que não estavam previstas nos contratos. Embora seja necessário conceder direitos residuais de controle, é a partir de tais brechas contratuais que gestores podem não atuar em função dos melhores interesses dos investidores. Frente a essa discussão, Fama e Jensen (1983) argumentaram que uma fácil solução para controlar problemas de agência seria restringir as reivindicações de controles residuais de agentes frente à tomada de importantes decisões que comprometessem o valor da firma e os interesses dos investidores.

Shleifer e Vishny (1997) argumentaram que uma outra forma de controlar o comportamento abusivo dos gestores seria a concentração de propriedade. A presença de grandes acionistas proporcionaria incentivos e meios para a aquisição de informações sobre os investimentos em projetos de longo prazo e criação de valor pela firma. No entanto, grandes acionistas são aqueles que detêm maior quantidade de ações com direito ao controle e, a sua presença na administração da firma pode gerar outro tipo de problema de agência, ocasionado pelo conflito entre os acionistas que detêm maior controle (acionistas controladores) e os acionistas com controle reduzido (acionistas minoritários). Considerando que os acionistas controladores teriam maior acesso e melhor qualidade sobre as informações financeiras da firma, acionistas minoritários poderiam ser prejudicados pelo déficit de informação, além da possibilidade de expropriação de suas riquezas pelo acionista controlador (LA PORTA et al., 1998, 1999).

Frente aos problemas mencionados devido à separação entre propriedade e controle, os investidores vêem a necessidade do monitoramento dos gestores e da influência dos grandes acionistas. Dessa forma, a reunião dos meios de monitoramento, assim como, a adoção de mecanismos que reduzam a presença de assimetria de informação, dos custos de agência e melhorem o relacionamento de agência, é entendido como Governança Corporativa. Ao longo dos anos, diversas definições para a governança corporativa foram dadas, no entanto, todas baseiam-se em quatro princípios, sendo eles: a igualdade entre os acionistas, transparência nas informações, prestação de contas e responsabilidade administrativa.

Para Shleifer e Vishny (1997), a governança corporativa estabelece formas pelas quais os fornecedores de capital asseguram o retorno sobre seus investimentos. Gillan e Starks (1998) definem a governança corporativa como um conjunto de leis, regras e fatores capazes de controlar as operações das firmas. Já La Porta et al. (2000) a definem como um conjunto 
de mecanismos pelos quais investidores externos (outsiders) ${ }^{7}$ se protegem contra a expropriação dos acionistas controladores e gestores (insiders) ${ }^{8}$. Para Becht, Bolton e Röel (2002), a governança corporativa preocupa-se com a resolução de problemas de ação coletiva entre os investidores dispersos e a reconciliação dos conflitos de interesse entre vários gestores e acionistas.

A estrutura de governança corporativa adotada nos países depende de fatores como cultura, legislação, sistema regulatório, organização interna das firmas, e as instituições de mercado (SIRQUEIRA, 2007). Ainda, segundo Rabelo e Silveira (1999), outro importante fator que influencia a governança corporativa é a própria natureza da estrutura de propriedade das firmas.

La Porta et al. (1997, 1998) sugeriram que a propriedade dispersa, como evidenciado por Berle e Means (1932) para as firmas norte-americanas, só seria possível em países com excelente proteção legal aos acionistas minoritários. Isso foi comprovado em estudo posterior, no qual, estudando 27 economias, incluindo o Brasil, La Porta et al. (1999) constataram que a propriedade pulverizada ocorria apenas nos Estados Unidos e Reino Unido já que, nos demais países, a propriedade geralmente era concentrada entre poucos acionistas. Ademais, para La Porta et al. (1999), a fraca proteção legal aos acionista minoritários combinada com uma propriedade concentrada e com a inserção dos grandes acionistas na administração da firma ocasionaria a criação de mecanismos para que a regra "uma ação - um voto" fosse desviada. Em outras palavras, grandes acionistas criariam mecanismos para emitir ações que apenas concedessem direito a propriedade e não ao controle e, dessa forma, se manteriam no controle administrativo da firma.

Dessa forma, a estrutura de propriedade pode ser classificada de duas formas: direta sendo dispersa (pulverizada) ou concentrada e indireta (piramidal). Na propriedade dispersa, nenhuma entidade ou pessoa detém quantidade suficiente de ações com direito a voto para controlar a firma. Já a propriedade concentrada possui acionistas que detém a maioria das ações com direito a voto (mais do que 50\% das ações, no caso do Brasil), sendo estes acionistas denominados como acionistas controladores. De acordo com a natureza deste acionista controlador pode-se classificar a firma entre: controle familiar, estatal, institucional, estrangeiro, cooperativas, dentre outras. Já uma estrutura de propriedade indireta (piramidal) caracteriza-se como um conjunto de firmas legalmente independentes controladas pelo

\footnotetext{
${ }^{7}$ Investidores outsiders são aqueles que não participam ativamente das atividades da firma.

${ }^{8}$ Insiders são os gestores e os acionistas controladores que participam ativamente na administração da firma e, que por isso, poderiam obter informações privilegiadas sobre os investidores outsiders.
} 
mesmo acionista (líder do grupo) por meio de uma estrutura que permite a este acionista controlar as demais firmas pertencentes à estrutura com uma pequena parcela de capital social, possibilitando assim, uma discrepância entre direitos de voto e direitos de fluxo de caixa (BIANCO e CASAVOLA, 1999). Para efeito de exemplificação, a figura 1 esquematiza a estrutura de propriedade piramidal da firma Grendene S.A.

Figura 1: Esquema de Propriedade Piramidal da Grendene S.A

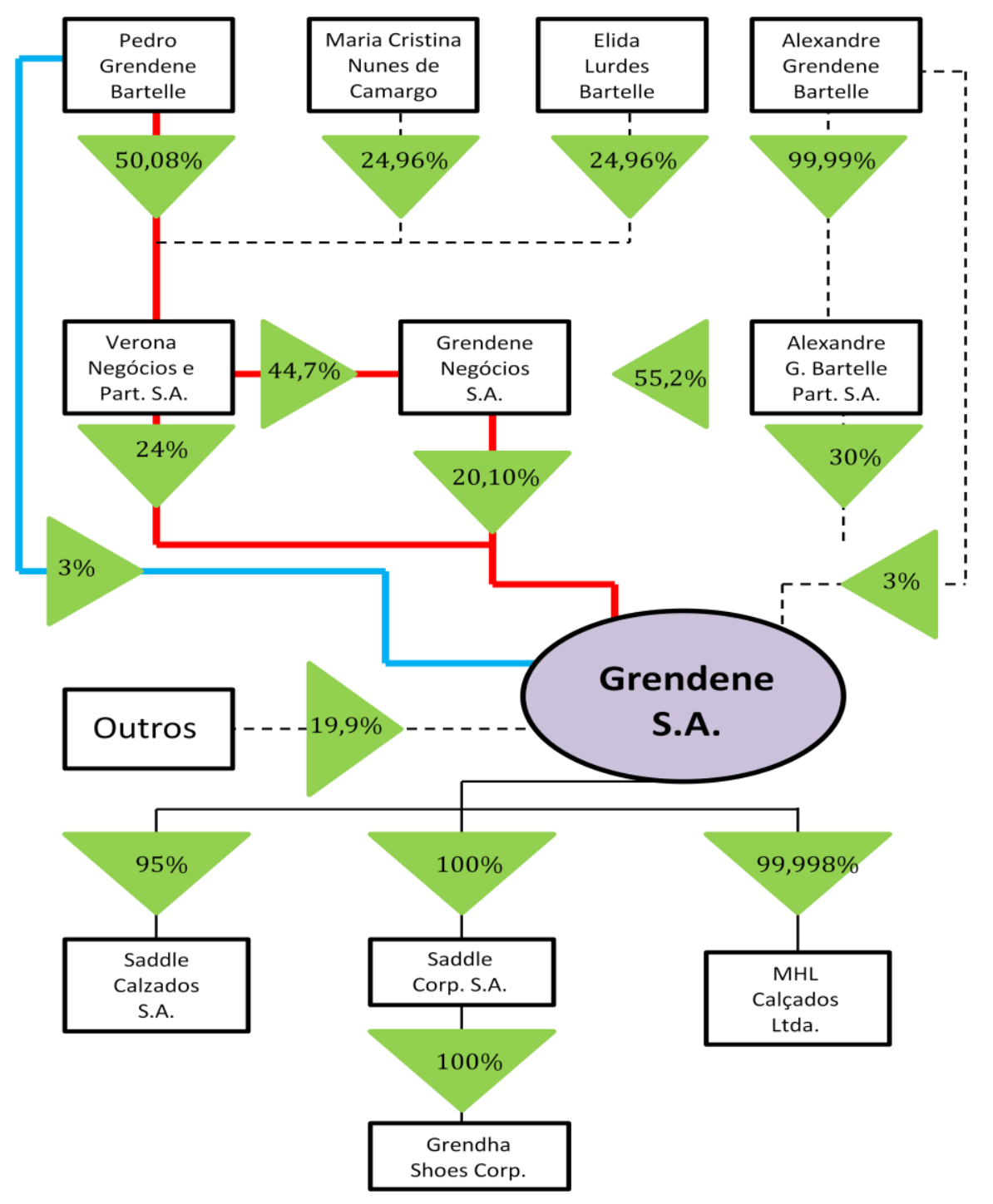

Notas: Grifado em azul - Propriedade Direta; Grifado em vermelho - Propriedade Indireta: trajeto (I) e (II). Fonte: Revista Valor Econômico - Nov/2007 p. 189. 
A figura 1 mostra a estrutura de propriedade piramidal da empresa Grendene no ano de $2007^{9}$. Nota-se que um dos maiores acionistas, Pedro Grendene Bartelle, possui diretamente 3\% do direito de propriedade da Grendene S.A. Entretanto, por meio de uma estrutura de propriedade piramidal, ele possui: (I) 50,08\% da Verona Negócios e Participações S.A que, por sua vez, detém $24 \%$ do direito de propriedade da Grendene S.A.; (II) 50,08\% da Verona Negócios e Participações S.A que detém 44,7\% da Grendene Negócios S.A e que, por sua vez, possui $20,10 \%$ de participação na Grendene S.A. Portanto, o Pedro G. Bartelle possui indiretamente $16,05 \%$, ou seja, (I) $+(\mathrm{II})=(0,5008 \times 0,24)+(0,5008 \times 0,4470$ x 0,2010). Consequentemente, somando os direitos via propriedade direta e indireta, tem-se que Pedro G. Bartelle possui 19,05\% do direito de propriedade da Grendene S.A.

Além da participação dos grandes acionistas no monitoramento das atividades dos gestores, outros mecanismos foram instituídos para a redução da assimetria de informação entre acionistas controladores e minoritários e entre gestores e acionistas. Para a melhor atuação da estrutura de governança corporativa das firmas, criaram-se mecanismos de regulação interna e externa para controlar assimetria de informações. Nos mecanismos externos, instituídos no ambiente externo à firma, classifica-se o ambiente legal e regulatório do país, mercado de aquisição e fusão, competição no mercado de produtos, auditores e agentes do mercado financeiro.

Já os mecanismos internos de governança corporativa são instituídos no ambiente interno da própria firma, sendo instrumentos de interferência direta aos gestores no intuito de aumentar o peso das reivindicações dos investidores e diminuir o risco de expropriação, além de prevenir ou corrigir a política adotada pelo gestor. Dentre os principais mecanismos internos, além da participação de grandes acionistas e sua interferência na atividade dos gestores, destacam-se grandes credores, o conselho de administração e as políticas de incentivos aos gestores para o alinhamento de interesses com os acionistas.

Nos itens seguintes serão apresentados alguns dos mecanismos de governança corporativa, ressaltando suas principais características e os principais estudos que os envolvem, tanto para o mercado brasileiro quanto para o internacional.

\footnotetext{
${ }^{9} \mathrm{O}$ esquema piramidal da empresa Grendene foi escolhido aleatoriamente. Este esquema serve apenas para exemplificar uma estrutura de propriedade piramidal e o cálculo do percentual de direito de propriedade. A fonte pesquisada não apresentava o percentual de direito de voto de cada acionista.
} 


\section{a) Grandes credores e Dívida}

Grandes credores como bancos e outras instituições financeiras podem ser considerados investidores potencialmente ativos. Com o fornecimento de capital, grandes credores necessitam confiar nas atividades da firma e no pagamento pelo empréstimo concedido. Em vista disto, os credores procuram obter garantias para saber a real situação financeira da firma e sua disponibilidade para arcar com o pagamento do principal e dos juros, utilizando como instrumento essencial os relatórios anuais emitidos pela empresa. Se a firma possui interesse em manter um relacionamento confiável com credores, ela fornecerá ferramentas necessárias para que suas condições financeiras sejam investigadas e o empréstimo seja concedido. Quanto mais transparentes forem as informações, maior será a probabilidade de esta firma obter o financiamento a um juro mais acessível, ao contrário de outras firmas com contradições nas informações.

Além disso, segundo Silveira (2002), ao conceder o financiamento, os credores podem estabelecer duas formas de supervisionamento sobre a firma: (1) quando a empresa não cumpre com o pagamento da dívida, os credores receberiam direitos de controle, visto que a concessão de financiamento pode ser entendida como um investimento na firma e os credores, como acionistas; e (2) a concessão de empréstimos de curto prazo insuficientes para fornecer todo o capital necessário para o investimento da firma forçaria os tomadores de empréstimo a requisitar outro financiamento, e obter um melhor desempenho.

Sob um contexto geral, a dívida, gerada a partir do relacionamento entre a firma e os credores, pode ser entendida como um mecanismo disciplinador aos gestores, especialmente se a sua duração for de curto prazo (TIROLE, 2006). Como grande parte dos problemas de agência está relacionada com a má utilização do fluxo de caixa livre ${ }^{11}$, a dívida interferiria na atuação dos gestores das seguintes formas: (1) com o dispêndio de fluxo de caixa na dívida, diminuiria a possibilidade de existência do fluxo de caixa livre, reduzindo o potencial de investimentos em projetos não lucrativos, e (2) com a dívida, os gestores estariam sujeitos ao controle do mercado financeiro e do risco de inadimplência, melhorando seu comportamento e, consequentemente, reduzindo problemas relacionados ao fluxo de caixa, risco de falência e perdas contratuais de funcionários.

\footnotetext{
${ }^{11}$ Fluxo de caixa livre, calculado pelo fluxo de caixa operacional descontado os empréstimos a serem pagos, é o montante financeiro que estará disponível para a realização de investimentos e pagamento de dividendos aos acionistas. Visto que este conhecimento é restrito entre poucos acionistas e/ou gestores, a presença de fluxo de caixa livre gera conflitos de agência já que acionistas minoritários o veriam como um potencial instrumento para a expropriação de suas riquezas.
} 
Outro importante mecanismo de governança corporativa para a proteção dos acionistas corporativa é o conselho administrativo.

\section{b) Conselho de Administração}

Em princípio, o conselho de administração monitora os gestores em favor dos acionistas. Ele é utilizado para definir ou aprovar as decisões mais importantes e as principais estratégias corporativas, tais com: alienação de bens, investimentos ou aquisições e propostas de compradores. Para um bom funcionamento desse monitoramento, é preciso que o conselho seja independente, ou seja, que um diretor não possua vínculo empregatício, não preste serviços para a firma e, principalmente, não possua conflitos de interesse no cumprimento da sua missão de supervisionamento (Tirole, 2006). Ainda, de acordo com Hermalin e Weisbach (2003) e Mallin (2004), o conselho realiza o processo de interação entre gestores e investidores, além de ser um importante mecanismo interno para solucionar problemas de agência. Entretanto, para que isso seja possível, o conselho deve ser primariamente responsável pelo processo de contratação e acompanhamento da gestão executiva.

Diversos códigos de governança corporativa instituídos no mundo exaltam a importância de um conselho de administração independente e com a participação ativa dos conselheiros e com um número de conselheiro adequado para a realização de suas atividades com excelência ${ }^{12}$. Dessa forma, recentes estudos como os de Hermalin e Weisbach (2003), Raheja (2005), Setia-Atmaja (2009) procuram analisar como o não cumprimento destes requisitos poderia influenciar o relacionamento de agência entre acionistas e gestores.

Tendo por base os princípios básicos estipulados aos conselhos de administração, Linck, Netter e Yang (2008) analisaram as tendências e os determinantes da estrutura do conselho de administração de uma amostra de 7000 firmas no período de 1990 a 2004. Considerando o tamanho das firmas, composição, independência e tamanho do conselho, os autores evidenciaram que os conselhos administrativos tornaram-se maiores e mais independentes na década de 90. Entretanto, de acordo com os autores, firmas pequenas apresentaram um maior aumento na independência do conselho, enquanto firmas de grande porte diminuíram o tamanho de seus conselhos. Os resultados apresentados são condizentes com a hipótese de que as firmas escolhem a estrutura de seus conselhos baseadas nos custos e nos benefícios de seu monitoramento.

\footnotetext{
${ }^{12}$ No Brasil, exige-se em lei o número mínimo de três conselheiros.
} 
No entanto, Raheja (2005) explicou que o tamanho dos conselhos está associado ao relacionamento de agência entre acionistas e gestores. Como enfatizado pelo autor, o conselho será pequeno quando existir um alinhamento de interesse entre acionistas e insiders, pois com o alinhamento, a probabilidade dos insiders investirem em projetos não lucrativos diminui, ocasionando uma redução na necessidade do monitoramento exercido pelo conselho.

Com uma amostra de 316 firmas australianas de 2000 a 2005, Setia-Atmaja (2009) examinou a relação entre a independência do conselho e a influência dos acionistas controladores sobre o conselho administrativo das firmas. Seus resultados mostraram que a concentração de propriedade tem um impacto negativo na independência do conselho. Para esse resultado, o autor considera duas possíveis explicações: (1) acionistas controladores preferem conselhos menos independentes para facilitar sua interferência nas decisões da firma, e (2) a presença de acionistas controladores com forte incentivos para monitorar gestores substitui o papel de monitoramento atribuído ao conselho.

Já para Hermalin e Weisbach (2003), a atuação do conselho está relacionada com características internas do próprio conselho. Firmas com grande concentração de diretores independentes ${ }^{13}$ e com pequenos conselhos administrativos tendem a tomar melhores decisões em relação a aquisições, poison pills ${ }^{14}$, compensação dos diretores e substituição do CEO ${ }^{15}$.

Examinando as práticas de governança corporativa de 118 firmas brasileiras de capital aberto em 2005, Black, Carvalho e Gorga (2010) evidenciaram que firmas de grande porte tendem a ter grandes conselhos, entretanto, conselhos menores apresentam-se mais eficazes no comprometimento de suas funções. No estudo, as firmas brasileiras apresentaram em média, 6,8 membros no conselho administrativo. Ao considerar a presença de conselheiros independentes, os autores constataram que a maioria das firmas possui conselheiros com vínculo empregatício com a empresa, sendo que a existência de conselheiros independentes é quase nula entre todas as firmas analisadas. Além disso, em muitas firmas, os diretores outsiders geralmente representam o acionista controlador.

\footnotetext{
${ }^{13}$ De acordo com Hermalin e Weisbach (2003), diretores independentes (outsiders) não possuem vinculo empregatício com a firma, geralmente, são CEOs de outra empresa ou indivíduos que atuam em firmas de outro setor.

14 "Pilula de veneno" (poison pills) pode servir como proteção dos acionistas a atual gestão administrativa ou também, servir para melhorar o posicionamento da empresa para negociar possíveis aquisições podendo ser utilizada sem a prévia votação dos acionistas.

${ }^{15}$ Chief Executive Officer - diretor presidente da firma.
} 


\section{c) Fusões e Aquisições}

O mercado de controle corporativo é considerado um dos aspectos mais controversos da governança corporativa e está relacionado aos processos de aquisição e fusão das firmas. $\mathrm{O}$ processo de aquisição se inicia com um convite para compra de ações da firma ao preço anunciado. Essa oferta pode conter apenas uma parte ou todas as ações da firma, mas geralmente, o comprador está interessado em ações que concedam o controle acionário. Existem duas formas de aquisição da firma: aquisição com parte controladora e sem parte controladora. A aquisição controladora é caracterizada pelas transações de compra com 100\% das ações ou da compra de 50\% mais uma ação com direito ao controle da firma. As aquisições sem controle são aquelas cuja compra das ações não oferece o controle da firma, que em geral, são transações com menos de $50 \%$ da compra do capital social. Já as fusões são caracterizadas pela união das operações de duas firmas que deixam de existir separadamente, dando origem a uma nova empresa.

O processo de aquisição e fusão está intimamente relacionado com a adoção de boas práticas de governança corporativa. Como a decisão de aceitar ou rejeitar é atribuído as atividades do conselho de administração, a forma como a firma irá negociar este processo pode ser utilizada de maneira positiva aos acionistas, quando a venda da firma for negociada a um preço superior ao de mercado ou de maneira negativa, ao não aceitar a oferta quando esta seria interessante para os acionistas (Silveira, 2002). Dessa forma, o processo de aquisição ou fusão da firma é visto como uma maneira de monitoramento externo de governança corporativa ao exigir a boa conduta dos conselheiros, forçando-os a atribuir defesas às aquisições hostis tanto para a firma quanto para os investidores.

\section{d) Mercado e Competição}

O mercado é uma das instituições mais importantes da governança corporativa. Röe (2005) denomina três tipos de mercado como sendo centrais: o mercado de venda do produto, o mercado de capital e o mercado de trabalho gerencial. Essa denominação é dada baseandose nas premissas do próprio mercado:

- Se a firma não vende bem o seu produto, rapidamente ela desaparece do mercado;

- Se a firma não pode aumentar seu capital, ela não pode crescer;

- Se a firma não retém nem adquire bons gestores e empregados, ela desperdiçará 
seus recursos com profissionais não qualificados.

Uma boa relação entre os três tipos de mercado não é fácil. Uma boa tomada de decisão interna pode ajudar a firma a reagir bem às mudanças do mercado, a economizar capital e a certificar-se de que bons gestores irão optar em trabalhar na firma, além de ajudá-la a obter um bom desempenho.

Segundo Fama (1980), a firma é disciplinada pelo mercado devido à competição entre outras firmas que força a evolução de seus serviços e o monitoramento eficiente de todos os que nela estão envolvidos, principalmente em relação aos gestores. Além disso, o autor também afirma que a competição do mercado possibilita uma maior disciplina aos gestores e oportunidades promovidas pelo mercado.

Friedman (1953, apud Singh et al., 2002) sugere que a competição perfeita soluciona os problemas de separação de propriedade e controle das firmas, dado que o mercado competitivo selecionaria naturalmente as firmas por meio da maximização dos lucros. Porém, Shleifer e Vishny (1997) questionaram que a regulação exercida pelo mercado só seria possível em um mercado perfeito, já que no mundo real com a presença de problemas de assimetrias de informação, os investimentos realizados na produção do produto seriam perdidos caso o investimento não obtivesse o retorno esperado. Neste sentido, a competição no mercado de produtos exerceria uma regulação posterior ao momento do investimento, contudo, os investidores necessitam assegurar o retorno sobre os seus investimentos a um baixo risco.

Estudando as leis de proteção aos acionistas em diversos países pelo mundo, La Porta et al (1999), concluíram que a competição no mercado de produtos só seria possível em países como Estados Unidos e Reino Unido. Isso devia-se ao fato de esses países possuírem um mercado ativo, caracterizado pela grande difusão do controle acionário e pelo ótimo sistema legal, que ofereceria a melhor proteção aos acionistas minoritários em relação a todos os demais sistemas no mundo. Países em desenvolvimento, como o Brasil, possuem mercados imperfeitos e sofrem mais com a falta de transparência nas informações. Por este motivo, Singh (1998) argumenta que, provavelmente, esses mercados não proporcionarão solução satisfatória para problemas nas estruturas de governança corporativa de seus países.

A próxima seção tem por objetivo ressaltar as principais características de governança corporativa no Brasil, evidenciando os principais incentivos governamentais para o melhoramento do relacionamento de agência. 


\subsection{Governança Corporativa no Brasil}

"A governança corporativa é uma estrada com duas pistas, ambas na mesma direção. Uma visa ajudar a empresa a atingir suas metas estratégicas, enquanto que a outra tem como objetivo a criação de valor para todos os acionistas".

Gilberto Mifano, presidente do conselho de administração da BM\&FBOVESPA ${ }^{16}$.

A necessidade de financiamento a um custo reduzido para a realização de investimentos estimula a firma a buscar outras fontes de financiamento que não seja o capital próprio. Ainda que este seja a principal fonte de financiamento das firmas brasileiras, não se pode desprezar a importância da captação de recursos que essas firmas vêm realizando no mercado de títulos e bônus nacional e internacional, principalmente nos últimos anos. Com a abertura de capital, as firmas buscam investidores capazes de apoiar financeiramente a realização de seus projetos de investimento e, em troca, oferecem direitos de participação no controle ou no capital social.

A obtenção de recursos por meio de emissões de ações tem crescido significativamente nos últimos anos no Brasil. As emissões de ações realizadas em 2007 somaram R\$33,2 bilhões, representando um crescimento de 133,5\% em relação ao ano anterior; entretanto, em função da crise financeira de 2008, o número de emissões caiu para 11,6 bilhões em 2009. Grande parte desse crescimento está relacionada com a maior participação de investidores no mercado, o que evidencia a credibilidade e a confiança conquistadas pelo mercado. De acordo com a BM\&FBOVESPA, a percentagem de pessoas físicas no volume de ações negociadas passou de 23,01\% em 2007 para 26,67\% em 2008. Já a participação de investidores estrangeiros subiu de 34,5\% em 2007 para 35,5\% em 2008. A ampliação da participação desses tipos de investidores no mercado impulsiona a abertura de capital das empresas, contribuindo para a evolução do mercado de capitais brasileiro.

No entanto, a abertura de capital nem sempre é reflexo de grandes captações de recursos. Segundo Carvalho (2003), os benefícios proporcionados pela emissão de ações dependem da liquidez que a firma obterá no mercado de capitais. Como liquidez está relacionada ao número de participantes no mercado, os acionistas minoritários exercem um

\footnotetext{
${ }^{16}$ Trecho extraído do relatório de 2008 sobre as atividades da BM\&FBOVESPA.
} 
importante papel no desenvolvimento da negociação de papéis emitidos por empresas. Assim, ações com baixa liquidez devem proporcionar alguma vantagem para atrair investidores, o que normalmente é feito com a diminuição do preço de seus papéis. No entanto, acionistas minoritários apenas investirão em ações com baixa liquidez se notarem a existência de proteção aos seus direitos, caso contrário, procurarão investimentos considerados mais seguros.

Uma grande influência aos direitos dos acionistas minoritários está relacionada ao tipo de ações que o investidor possui. No Brasil existem dois tipos: as ordinárias nominativas $(\mathrm{ON})$ e as preferenciais nominativas $(\mathrm{PN})$. As ações ordinárias concedem participação no resultado da firma (dividendos) e direito de voto ao seu proprietário, sendo que cada ação equivale a um voto. Logo, o poder de decisão sobre o futuro da empresa concentra-se nos investidores com maior percentual de ações ordinárias. Já as ações preferenciais, como o próprio nome diz, outorgam prioridade no recebimento de dividendos e de reembolso do capital na hipótese de dissolução da empresa, mas, por lei, não disponibiliza poder de voto ao seu proprietário, o que não impede que a firma emita ações preferenciais com direito a voto. Os acionistas preferenciais estão mais preocupados com o lucro adquirido pela firma do que com o controle que ela possa lhes proporcionar.

Grande parte da oferta pública de ações no Brasil concentra-se na emissão de ações preferenciais. Isso está relacionado com o fato dos proprietários visarem à captação de recursos sem a implicação da perda de controle. Vale ressaltar que as ações que outorgam controle, as ações ordinárias, normalmente concentram-se em um pequeno grupo de investidores, geralmente famílias, que impedem a emissão de ações que alterem a estrutura de controle e a concentração da propriedade. Leal e Carvalhal-da-Silva (2008) analisaram a composição acionária do Brasil nos anos de 1998, 2000 e 2002 e notaram que, em média, um único acionista majoritário possui $77 \%$ dos direitos ao voto e que entre os três maiores acionistas concentra-se $87,41 \%$, deixando aos demais acionistas, uma pequena parcela de ações ordinárias. Logo, a emissão de ações preferenciais e consequentemente, a estrutura de propriedade piramidal tornam-se os principais mecanismos de separação entre os direitos de controle e de propriedade, o que pode ocasionar a concentração da propriedade, provocando problemas de agência entre acionistas minoritários e majoritários, além de muitas vezes ocasionar a expropriação da riqueza dos pequenos investidores por parte dos controladores.

Dessa forma, é notório que a adoção de bons mecanismos de governança corporativa tais como estrutura de propriedade dispersa, transparência, maior emissão de ações ordinárias, dentre outras características, influencia a decisão de investimento dos acionistas. 
Com o intuito de analisar os principais aspectos da governança no Brasil, McKinsey e Korn/Ferry (2001) fizeram um levantamento sobre o modelo de governança mais proeminente entre as empresas bem sucedidas no país. O modelo de governança no Brasil foi determinado por essas empresas que conseguiram superar períodos adversos da economia. Embora esse modelo não se aplique de maneira uniforme a todas as empresas, ele apresenta as principais características de muitas firmas brasileiras. O quadro 1 mostra as principais características do modelo de governança mais adotado no país.

Quadro 1: Modelo geral de governança corporativa brasileiro

\begin{tabular}{|c|c|}
\hline Aspectos de governança & Características \\
\hline Estrutura de propriedade & $\begin{array}{l}\text { - Altamente concentrada entre poucos acionistas } \\
\text { majoritários; } \\
\text { - Empresa com controle familiar ou compartilhado } \\
\text { entre poucos investidores com interesses alinhados por } \\
\text { meio de acordo entre acionistas; } \\
\text { - Acionistas minoritários pouco ativos. }\end{array}$ \\
\hline $\begin{array}{c}\text { Relação entre propriedade e } \\
\text { gestão executiva }\end{array}$ & $\begin{array}{l}\text { - Alta sobreposição entre propriedade e liderança } \\
\text { executiva, com membros do conselho representando os } \\
\text { interesses dos acionistas controladores. }\end{array}$ \\
\hline Estrutura do Conselho & $\begin{array}{l}\text { - Maioria de conselheiros internos e baixa demanda de } \\
\text { conselheiros externos e independentes; } \\
\text { - Pouca clareza na divisão dos papéis do conselho e } \\
\text { diretoria, principalmente em firmas familiares; } \\
\text { - Escassez de profissionais capacitados; } \\
\text { - Remuneração dos conselheiros é pouco importante; } \\
\text { - Nível de transparência adequado segundo a firma, mas } \\
\text { inadequado para investidores. }\end{array}$ \\
\hline
\end{tabular}

Fonte: McKinsey e Korn/Ferry (2001)

Como evidenciado pelo estudo de McKinsey e Korn/Ferry (2001), é possível perceber que a concentração de propriedade e de controle influencia as demais características da estrutura de governança corporativa no Brasil. Além disso, devido à alta concentração de propriedade, geralmente os conselheiros são escolhidos para representar apenas o acionista controlador, excluindo a representação de todos os acionistas. O estudo também evidenciou que, normalmente, em empresas familiares, os conselheiros são internos ou não profissionais, escolhidos pelo acionista controlador que apenas considera os laços familiares ou pessoais, desprezando os benefícios que a firma poderia ter com a inserção de conselheiros experientes e independentes. 
Um estudo subsequente sobre o panorama da governança corporativa no Brasil realizado pela Booz\&Company e IBGC em 2009, analisou o comprometimento das firmas em relação aos benefícios da governança corporativa e sua evolução do ano de 2003 a 2009 . O estudo mostrou que a participação do acionista controlador como membro do conselho reduziu-se em $18 \%$ das firmas e, uma maior inclusão de conselheiros independentes foi observada em 14\% delas, confirmando a evolução da diversidade do conselho de administração. $\mathrm{O}$ estudo também evidenciou os avanços das políticas de proteção aos acionistas minoritários e uma maior adoção de mecanismos como o tag along ${ }^{17}$, eleição de membro representativo para o conselho de administração, dentre outros, que visam a redução de conflitos entre acionistas minoritários e controladores.

Aldrighi e Mazzer (2007) analisaram a estrutura de propriedade e controle de firmas brasileiras de capital aberto no período de 1997 a 2002. Organizando e analisando dados do relatório Informativo Anual (IAN) ${ }^{18}$, cujas firmas de capital aberto são obrigadas a declarar a $\mathrm{CVM}^{19}$, os principais resultados obtidos exaltam que holdings e bancos representam mais de $33 \%$ das firmas de capital aberto. Os autores também constataram a grande incidência de firmas com controle familiar $(54,7 \%)$, seguidos pelo investidores estrangeiros $(18,4 \%)$. Além disso, a presença do acionista controlador é percebida em 77,6\% das firmas examinadas.

Tendo em vista as implicações ocasionadas pelas falta da adoção de boas práticas de governança corporativa na obtenção de recursos e a intensa necessidade de financiamento de investimentos ao menor custo possível, modificações no modelo brasileiro de governança corporativa adotado pelas organizações foram necessárias, principalmente em relação à proteção dos interesses dos acionistas minoritários, transparência das informações e profissionalização do Conselho Administrativo. Borges e Serrão (2005) analisaram as principais modificações institucionais e governamentais que contribuíram para a melhoria das práticas dos mecanismos externos de governança corporativa brasileiro. Dentre as mais importantes modificações, pode-se citar a criação do Instituto Brasileiro de Governança Corporativa (IBGC), a Nova Lei das SAs, a Lei 10.303 de 2001 e o Decreto 3.995 também de 2001 que concederam maior autonomia à Comissão de Valores Mobiliários (CVM), a criação dos quatro segmentos diferenciados de governança corporativa de listagem para as companhias abertas pela BM\&FBOVESPA: Nível 1, Nível 2, Novo Mercado e Bovespa Mais, e os incentivos oferecidos pelo BNDES, como por exemplo, a concessão de

\footnotetext{
${ }^{17}$ Tag along é uma vantagem concedida aos acionistas minoritários, garantindo-lhes direito de venda de suas ações a pelo menos $80 \%$ do valor venda das ações dos acionistas controladores.

${ }^{18}$ Informativo Anual, apresentado na próxima seção.

${ }^{19}$ Comissão de Valore Mobiliários (CVM), apresentado na próxima seção.
} 
empréstimos as firmas que adotam melhores práticas de governança corporativa. Cada um destes incentivos serão discutidos nas próximas sub-seções que se seguem.

\subsubsection{Instituto Brasileiro de Governança Corporativa (IBGC) ${ }^{20}$}

O Instituto Brasileiro de Governança Corporativa foi criado em 1995, com o principal objetivo de divulgar a importância da transparência na gestão das empresas, a igualdade dos direitos entre os sócios e a responsabilidade corporativa. O IBGC promove a adoção destes mecanismos, já que eles facilitariam o acesso das empresas no mercado de capitais e atrairiam investidores, possibilitando o aumento do valor da firma.

Em 1999, o IBGC lançou a primeira edição do "Código das Melhores Práticas de Governança Corporativa", cujo objetivo era atentar para a perpetuidade das organizações, contribuindo com valores e orientações de estratégias empresariais. Na primeira edição, o foco principal era o funcionamento, atribuições e composição do conselho de administração. Na segunda versão publicada em 2001, incluíram-se recomendações para os demais agentes de governança corporativa como os gestores, auditores independentes e o início do principio de prestações de contas. Já a terceira edição lançada em 2004, destacou-se pela inclusão de princípios de responsabilidade corporativa. A última edição publicada em 2009, passou a abranger temas proeminentes da recente crise financeira de 2008 e da evolução do mercado de capitais, estendendo os conceitos de boas práticas de governança corporativa a outras instituições, tais como governos, ONGs e fundos de pensão. Entre os principais temas abordados na versão atual podem-se citar as novas formas de participação dos acionistas com mais transparência e o maior detalhamento da atuação do conselho de administração.

Para evitar os problemas originários do desequilíbrio de poder entre os acionistas, o Código defende a maior propagação de ações com direito ao voto, além de recomendar que organizações com controle definido divulguem com clareza como o poder está distribuído. Em outras palavras, a firma deve informar aos demais sócios se o controle é dado diretamente por meio da maioria das ações ou por mecanismos de ampliação de controle como, por exemplo, ações sem direito ao voto, estruturas piramidais e restrições à aquisição de controle como as poison pills. No caso da transferência de controle, a oferta de compra de ações deve ser dirigida a todos os sócios nas mesmas condições, isto é, o comprador deve conceder direito a todos os acionistas venderem suas ações pelo mesmo preço a ser pago pelo

\footnotetext{
${ }^{20}$ Item elaborado com base nas informações disponibilizadas no site do Instituto.
} 
controlador $^{21}$. Além disso, o Código recomenda maior transparência das informações ao mercado, qualificação dos membros do conselho, tratamento justo entre todos os sócios e demais partes interessadas, prestação de contas e responsabilidade corporativa nos quais agentes de governança devem zelar pela sustentabilidade das organizações visando sua longevidade ${ }^{22}$.

\subsubsection{Reforma da Lei das Sociedades Anônimas (S.As)}

A reforma da Lei das Sociedades Anônimas $n^{\circ}$ 6.404, promulgada em 2001, pode ser considerada um grande avanço para a governança corporativa no Brasil do ponto de vista legal e regulatório. Essa reforma visou o fortalecimento e o desenvolvimento do mercado de capitais promovendo maior proteção aos acionistas minoritários, bem como o cumprimento da transparência nas diretrizes da firma e o dever de prestação de contas da administração das mesmas. Entre as principais medidas alteradas na nova Lei das SAs, Borges e Serrão (2005) destacam:

- Proteção aos acionistas minoritários no caso de fechamento de capital da companhia, obrigando a realização de oferta pública de ações por um preço justo;

- O limite de ações preferenciais permitido foi estipulado em 50\% do total de ações;

- Eleição de um membro para o Conselho de Administração por acionistas titulares de ações preferenciais que detenham pelo menos $10 \%$ do capital social da companhia;

- Eleição de um membro para o Conselho de Administração por acionistas minoritários, desde que os titulares possuam pelo menos $15 \%$ do total de ações com direito ao voto;

- Criação de vantagens efetivas às ações preferenciais, impondo que tais ações com direito restrito ou vetado ao voto somente serão negociadas no mercado de valores mobiliários se apresentarem pelo menos uma das características abaixo:

1. Direito ao dividendo de, no mínimo, $25 \%$ do lucro liquido do exercício, com prioridade a $3 \%$ do patrimônio líquido da ação e igualdade de condições com as ações ordinárias;

2. Garantia de dividendos no mínimo $10 \%$ superiores ao das ações ordinárias;

\footnotetext{
${ }^{21}$ Este direito dos acionistas é conhecido como tag along.

${ }^{22}$ Entende-se por agentes de governança como os sócios, administradores (gestores, conselho de administração e executivos), conselhos fiscais e auditores.
} 
3. Serem incluídas em oferta pública de alienação de controle (tag along), assegurando dividendos pelo menos igual ao das ações ordinárias.

- Possibilidade de instituir-se estatutariamente a arbitragem como mecanismo de solução dos conflitos entre acionistas controladores e minoritários ou gestores e acionistas.

\subsubsection{Comissão de Valores Mobiliários (CVM)}

A Comissão de Valores Mobiliários é uma entidade federal com o objetivo de fiscalizar e regular o registro de sociedades anônimas de capital aberto e as informações prestadas ao público. Atualmente, supervisiona um mercado em intensa expansão que conta com cerca de 34 mil participantes divididos entre companhias abertas, auditores, corretoras e distribuidoras, analistas de valores mobiliários, fundos de investimento, consultores, agentes autônomos, administradores de carteira, dentre outros.

Na última década, a CVM aderiu as exigências dos investidores em relação à adoção de práticas de governança corporativa, incentivando as organizações a adquirirem boas práticas de governança. $\mathrm{Na}$ instrução $\mathrm{CVM}^{\circ} 358$ de janeiro de 2002, a CVM impôs regras claras para a divulgação de informações iguais e simultâneas para todos, o que permitiu aos investidores e potenciais investidores decidir de maneira consciente a compra ou a vendas das ações da firma. Logo no mesmo ano, a CVM publicou sua cartilha de recomendações sobre a governança corporativa com o objetivo de promover o desenvolvimento do mercado de capitais, auxiliando as firmas nas questões que poderiam influenciar significativamente a relação entre administradores, conselheiros, auditores independentes, acionistas controladores e minoritários. As recomendações da CVM consideram padrões superiores aos exigidos pela lei brasileira e pela própria regulamentação da CVM e por isso, não decorre de punição caso essas práticas não sejam cumpridas. A única exigência feita é a inclusão dos níveis de adesão as práticas recomendadas nos relatórios de informações anuais submetidas a CVM, em que a não adoção das práticas devem ser apenas explicadas.

\subsubsection{Bolsa de Valores, Mercadorias e Futuros (BM\&FBOVESPA)}

A Bolsa de Valores, Mercadorias e Futuros foi criada em 2008 com a integração entre a Bolsa de Mercadorias e Futuros (BM\&F) e a Bolsa de Valores de São Paulo (BOVESPA), sendo uma das maiores bolsas do mundo em valor de mercado. Possui, como um de seus 
objetivos, a administração dos mercados organizados de títulos e valores mobiliários, zelando pela organização, funcionamento e desenvolvimento de mercados livres e abertos para a negociação de títulos ou contratos que estejam relacionados direta ou indiretamente a ativos na modalidade à vista ou de liquidação futura (Estatuto Social - BM\&FBOVESPA).

Tendo em vista sua responsabilidade com o mercado de capitais e sua constante preocupação em atrair investidores na presença de um ambiente favorável e seguro para a captação de recursos a um custo reduzido, a BM\&FBOVESPA considera de grande relevância o fornecimento de incentivos para o desenvolvimento do mercado de capitais. Frente aos baixos desempenhos do mercado na década de 1990 e início da década de 2000 que, em parte, pôde ser atribuído a falta de qualidade das ações ofertadas aos investidores, a BM\&FBOVESPA, na época a Bolsa de Valores de São Paulo (BOVESPA), decidiu adotar medidas de governança corporativa para remediar o desempenho do mercado de capitais, criando em 2000, os Níveis Diferenciados de Governança Corporativa (Nível 1 e Nível 2) e o Novo Mercado; posteriormente, em 2008, criou-se mais um nível, denominado Bovespa Mais.

Os segmentos de listagem da BM\&FBOVESPA para empresas abertas, compostos pelos Níveis 1 e 2, Novo Mercado e Bovespa Mais, têm como objetivo estimular os interesses dos investidores juntamente com a valorização das companhias. Empresas listadas nesses segmentos oferecem aos seus investidores melhorias no âmbito da ampliação aos direitos dos acionistas minoritários e no aumento da transparência das firmas, facilitando assim, o acompanhamento do desempenho da empresa pelos seus acionistas.

Entretanto, para as firmas inserirem-se aos segmentos de listagem, estas oficializam um compromisso com a BM\&FBOVESPA em que as partes comprometem-se a exercer os requisitos exigidos pelo segmento específico. Cabe ressaltar que o ingresso a um dos segmentos é realizado de forma voluntária. O quadro 2 disponibiliza os principais requisitos a serem cumpridos em cada um dos segmentos.

Com as informações disponibilizadas no quadro 2, percebe-se que as firmas inseridas no Nível 1 comprometem-se, principalmente, com melhorias às informações prestadas ao mercado e com a dispersão acionária, enquanto que as do Nível 2, comprometem-se a adotar, além das regras do Nível 1, a arbitragem como solução de eventuais conflitos entre os sócios. Já em relação ao Novo Mercado, a principal inovação em relação aos Níveis Diferenciados, é a exigência de que o capital social da firma seja composto apenas por ações ordinárias. 
Quadro 2: Principais exigências: Nível 1, Nível 2 e Novo Mercado

\section{Nível 1}

- Melhoria nas informações prestadas nas Informações Trimestrais (ITR), nas Demonstrações Financeiras Padronizadas (DFPs) e nas Informações Anuais (IAN) encaminhadas a CVM e a BM\&FBOVESPA.

- Manutenção de uma parcela mínima de ações em circulação que represente $25 \%$ do capital (free float);

- Da realização de distribuições públicas de ações, adotar mecanismos que favoreçam a dispersão do capital;

- $\quad$ Realização de reuniões públicas com analistas e investidores, ao menos uma vez por ano;

- Apresentação de um calendário anual com a programação dos eventos corporativos, tais como, assembléias, divulgação de resultados, dentre outros;

- Divulgação dos termos dos contratos firmados entre a firma e partes relacionadas; e

- Divulgação, em bases mensais, das negociações de valores mobiliários e derivativos de emissão da firma por parte dos acionistas controladores.

\section{Nível 2}

- Cumprir todas as regras do Nível 1;

- Divulgação de demonstrações financeiras de acordo com padrões internacionais IFRS ou US GAAP ${ }^{23}$;

- Conselho de Administração com mínimo de 5 membros e mandato unificado de até 2 anos, permitida a reeleição;

- Mínimo de 20\% de conselheiros independentes;

- Direito ao voto para ações preferenciais em algumas ocasiões como, por exemplo, na fusão, cisão, incorporação da firma;

- Tag along (ver nota 17);

- Oferta pública de aquisição de todas as ações em circulação, pelo valor econômico, nas hipóteses de fechamento do capital ou cancelamento do registro de negociação no Nível 2;

- Adesão à Câmara de Arbitragem do Mercado para resolução de conflitos societários.

\section{Novo Mercado}

- Todas as exigências do Nível 2, exceto a que faz referência as ações preferenciais;

- Oferta pública de aquisição de todas as ações em circulação, pelo valor econômico, nas hipóteses de fechamento do capital ou cancelamento do registro de negociação no Novo Mercado;

- Proibição de ações preferenciais;

Fonte: Quadro elaborado a partir de informações disponibilizadas no site da BM\&FBOVESPA

${ }^{23}$ IFRS: International Financial Reporting Standards; US GAAP: United States Generally Accepted Acconting Principles. São normas internacionais de publicação dos balanços anuais que facilitam a disponibilidade de informações aos acionistas internacionais e nacionais. 
O Bovespa Mais foi criado em 2008 com a intenção de tornar o mercado de capitais mais acessível às empresas que visam ingressar no mercado de capitais de forma gradativa, especialmente, àquelas que sejam atrativas ao investidor e necessitam de financiamento a longo e médio prazo, como por exemplo, empresas de pequeno e médio porte. Sendo um incentivo para as empresas iniciantes no mercado acionário, o Bovespa Mais estabelece o cumprimento de algumas regras, exibidas no quadro 3, para que, no futuro, essas firmas venham a aderir ao segmento do Novo Mercado. Dentre essas regras abaixo listadas, ressalte a negociação e emissão de apenas ações ON.

Quadro 3: Exigências do Bovespa Mais

\section{Bovespa Mais}

- Somente ações ON podem ser negociadas e emitidas, mas é permitida a existências de ações PN;

- $25 \%$ de free float até o sétimo ano de listagem, ou até alcançar condições mínimas de liquidez;

- É facultativo a divulgação de demonstrações financeiras de acordo com padrões internacionais IFRS ou US GAAP;

- Não há regras para o número mínimo de conselheiros, sendo assim, a firma deve dispor do número mínimo exigido pela legislação;

- Adesão à Câmara de Arbitragem do Mercado para resolução de conflitos societários.

Fonte: Quadro elaborado a partir de informações disponibilizadas no site da BM\&FBOVESPA

\subsubsection{Banco Nacional de Desenvolvimento Econômico e Social (BNDES)}

O Banco Nacional de Desenvolvimento Econômico e Social (BNDES) é um órgão do governo federal considerado o instrumento fundamental no financiamento de longo prazo para a realização de investimentos em todos os setores da economia. Com o objetivo de proporcionar o desenvolvimento do país, apóia e incentiva projetos e empreendimentos que conduzam ao crescimento nacional, principalmente projetos relacionados à agricultura, indústria, infraestrutura e comércio e serviços, disponibilizando assim, condições especiais para micro, pequenas e médias empresas.

Com o intuito de estimular o fortalecimento do mercado de capitais e aumentar o número de participantes ativos no mercado, o BNDES opera como subscritor de valor mobiliário em empresas de capital aberto ou que, no médio prazo, venham a ingressar no mercado de capitais. Entre os principais objetivos de sua atuação no mercado de capitais, destacam-se: 
- O fortalecimento do mercado de capitais por meio de operações no Novo Mercado e Bovespa Mais, visando principalmente, difundir o conceito e incentivar a governança corporativa pelas empresas, ampliar a demanda e a liquidez em valores mobiliários, e contribuir para a democratização e o fortalecimento da estrutura de capital das empresas;

- O desenvolvimento de produtos que tornem o mercado de capitais mais atrativo e seguro para o pequeno investidor;

- O apoio a pequenas e médias empresas inovadoras e o desenvolvimento de indústrias de fundos fechados.

Além dos objetivos descritos acima, convém evidenciar que o BNDES considera a adoção de práticas de governança corporativa como um dos requisitos preferenciais para a aprovação do financiamento.

O próximo capítulo tem por objetivo realizar uma revisão de literatura a respeito das decisões de investimento na presença da restrição financeira. Em um segundo momento, descreve-se os principais estudos que relacionam a influência da governança corporativa nas decisões de investimento das firmas frente a restrições de financiamento. 


\section{Aspectos de Governança Corporativa e Restrição Financeira nas decisões de investimento da firma.}

A identificação do comportamento das decisões de investimento empresarial tem sido um tema de grande importância na literatura da teoria do investimento, não somente no que se refere às decisões de orçamento de capital no âmbito da firma, mas principalmente devido à sua relação com o desenvolvimento financeiro. A compreensão dos fatores que influenciam e restringem essas decisões torna-se de grande relevância, principalmente para economias em desenvolvimento como a do Brasil.

No entanto, embora aspectos como a liberalização bancária, estabilização da economia, princípios de governança corporativa dentre outros tenham reduzido as dificuldades nas condições de captação de recursos pelas empresas, o volume de autofinanciamento continua a ser a principal condição de crescimento das firmas brasileiras. Essa forte dependência de recursos internos implica em uma considerável restrição a novos investimentos, já que tais recursos são altamente limitados.

No âmbito internacional, as evidências da importância do autofinanciamento têm sido mostradas pela literatura do investimento. Os mais diferentes estudos têm apresentado evidências de que diferentes graus e tipos de restrições impostas pelos mercados de capitais e de crédito contrapõem a expansão do investimento em diversos países. A capacidade financeira de diferentes firmas obterem financiamento a diferentes custos resulta em diferentes taxas de crescimento entre firmas. Neste sentido, têm-se incorporado nos desenvolvimentos mais recentes combinações que discutem a consistência das estimações baseadas nos fundos internos e as características financeiras como meio adequado para testar a assimetria de informações e a presença de restrição financeira nas decisões de investimento da firma. Dessa forma, torna-se fundamental considerar na análise do comportamento do investimento a heterogeneidade entre as firmas.

Testar a existência de restrição financeira no comportamento do investimento corporativo não tem sido uma tarefa fácil. Diversos critérios têm sido utilizados na literatura para classificar as firmas em grupos, de tal forma que se possa diferenciar e identificar uma firma como restrita financeiramente. Segundo Kaplan e Zingales (1997) uma firma é considerada restrita financeiramente se os custos ou a disponibilidade de fundos externos a impedem de realizar novos empreendimentos que teria escolhido se recursos internos estivessem disponíveis. Para Lamont, Polk Saá-Requejo (2001), restrição financeira é 
interpretada como os atritos que impedem a firma de realizar todos os investimentos por ela desejados. Essa incapacidade de conseguir investimento pode estar relacionada com a falta de crédito, com a dependência de empréstimos bancários ou com a falta de liquidez de ativos. Já para Bond e Reenen (2003), uma firma é restrita financeiramente se um crescimento inesperado na disponibilidade de seus recursos internos provocar um aumento nos gastos com investimentos, sem que este aumento proporcione qualquer tipo de informação sobre o potencial de sua lucratividade futura.

A discussão sobre o papel financeiro nas decisões de investimento corporativo intensificou-se no final da década de 80 com o importante trabalho de Fazzari, Hubbard e Petersen (1988). Nesse estudo, os autores analisaram o comportamento de 422 firmas americanas no período de 1969 a 1984. A amostra foi classificada em três grupos, conforme a política de pagamento de dividendos, tendo como objetivo identificar a presença de restrição financeira. Os autores consideraram o papel dos fundos internos por meio da introdução do fluxo de caixa em três diferentes especificações empíricas: neoclássico, $q$ de Tobin e Acelerador. A introdução desta variável de liquidez no modelo da equação do investimento teve como propósito testar a hipótese de assimetria de informação. O principal resultado encontrado mostrou que as 49 firmas que pagavam menor taxa de dividendos apresentaram uma sensibilidade do investimento ao fluxo de caixa distinta e significativamente maior do que o grupo com maior taxa de pagamento de dividendos. Isso permitiu concluir que firmas com menor taxa de pagamento de dividendos eram mais restritas financeiramente. A partir do resultado encontrado, os autores inferiram a existência de uma relação monotonicamente crescente entre a sensibilidade do investimento ao fluxo de caixa e o grau de restrição de crédito, ou seja, quanto maior a sensibilidade do investimento à disponibilidade de recursos internos, maior seria o grau de restrição financeira da firma.

O estudo de Fazzari et al. (1988) gerou uma intensa discussão a respeito da sensibilidade do investimento ao fluxo de caixa como forma de identificar a presença da restrição financeira. Estudos como os Devereux e Schiantarelli (1990), Hoshi, Kashyap e Scharfstein (1990), Schaller (1993), Gilchrist e Himmelberg (1995) e Hsiao e Tahmiscioglu (1997) utilizaram distintos critérios de classificação da amostra, como por exemplo, tamanho das firmas, idade, setor, pagamento de dividendos, afiliação com bancos, estrutura de propriedade, intensidade de capital, dentre outros, e obtiveram resultados consistentes com as estimativas de Fazzari et al. (1988).

No entanto, Kaplan e Zingales (1997) questionaram a validade da sensibilidade do investimento ao fluxo de caixa como critério de identificação da restrição financeira e 
argumentaram que não haveria razão teórica para que a sensibilidade do investimento ao fluxo de caixa fosse uma função monotônica entre fundos internos e restrição financeira. A crítica foi fundamentada em resultados empíricos, no qual os autores utilizaram as 49 firmas do grupo com baixo pagamento de dividendos e as reclassificaram conforme seus desempenhos operacionais. Os resultados mostraram que apenas 15\% das firmas poderiam ser realmente consideradas restritas financeiramente. Os demais $85 \%$ das firmas não poderiam ser classificado como restritas financeiramente, visto que estas firmas poderiam aumentar seus investimentos por meio de recursos externos ou reservas de caixa. Além disso, a análise da sensibilidade do investimento ao fluxo de caixa mostrou que firmas consideradas menos restritas financeiramente apresentaram menor sensibilidade do investimento ao fluxo de caixa quando comparadas aos demais grupos de firmas.

Rebatendo as críticas, Fazzari et al. (2000) alegaram que apenas classificar as firmas de acordo com os desempenhos operacionais não promoveria condições suficientes para identificar a presença de restrição financeira. Os autores argumentaram que a análise realizada por Kaplan e Zingales (1997) falhava ao capturar a abordagem teórica da maioria dos estudos anteriores, além de seus resultados serem de difícil interpretação. Os autores também alegaram que se basear em uma pequena amostra de 49 firmas não poderia sustentar com magnitude os resultados obtidos. Em resposta a Fazzari et al. (2000), Kaplan e Zingales (2000) citam o trabalho de Cleary (1999), o qual considera uma amostra de 1317 firmas americanas no período de 1987 a 1994 classificada de acordo com seu status financeiro, e encontra resultados consistentes as suas conclusões.

Com as controvérsias entre Fazzari et al. (1988) e Kaplan e Zingales (1997) ainda não resolvidas, diferentes estudos investigaram a sensibilidade do investimento ao fluxo de caixa analisando a existência real de correlação entre o investimento e o fluxo de caixa.

Gomes (2001) estudou o comportamento do investimento quando firmas enfrentavam elevados custos ao financiamento externo. Utilizando uma estrutura neoclássica e considerando efeitos do erro de medida sobre o estoque de capital, o autor concluiu que a presença de restrição de liquidez poderia estar relacionada com a existência de fricções financeiras que não seriam expressivas para obter os efeitos do fluxo de caixa, ou seja, os efeitos da restrição financeira estariam incluídos no valor de mercado utilizado como proxy para oportunidades futuras de investimento ( $q$ de Tobin).

Povel e Raith (2001) e Cleary, Povel e Raith (2007) apresentaram um importante resultado para a literatura da sensibilidade do investimento ao fluxo de caixa. Os autores definiram uma firma como restrita financeiramente quando ela necessita recorrer ao capital 
externo, mas enfrenta dificuldades no mercado de capitais devido às imperfeições do próprio mercado (Povel e Raith, 2001). A partir desta definição, a firma pôde ser considerada "mais restrita" do que as demais de acordo com sua necessidade de financiamento externo e com as dificuldades enfrentadas com os altos custos do financiamento, resultante da assimetria de informação entre firma e investidores. Analisando a relação entre a disponibilidade de fundos internos e investimento, os autores constataram que existe uma relação em forma de $\mathrm{U}$ entre investimentos e disponibilidade de fundos internos, ou seja, dependendo do nível de fundos internos, as firmas aumentariam ou diminuiriam sua quantidade de investimentos, o que influenciaria a sensibilidade ao fluxo de caixa. Por outro lado, as imperfeições do mercado reduziriam os investimentos das firmas e as tornariam mais sensíveis as flutuações dos níveis de fluxo de caixa. Com este resultado, os autores puderam mostrar que as formas de interpretação da restrição financeira gerariam diferentes resultados relacionados aos investimentos da firma. De acordo com Cleary et al. (2007):

\footnotetext{
"The key to obtaining estimates consistent with Fazzari et al. (1988) is to classify firms using a proxy for the degree of asymmetric information in the capital markets, and to eliminate observations for financially weaker firms. The key to obtaining findings consistent with Kaplan and Zingales (1997) and Cleary (1999) is to use an index ${ }^{24}$ related to internal funds to classify firms. (p. 30)"
}

Em outras palavras, para se obter resultados consistente aos de Fazzari et al. (1988) bastaria eliminar da amostra firmas em dificuldades financeiras, isto é, aquelas que apresentaram fluxo de caixa negativo. Já para se obter resultados consistentes a Kaplan e Zingales (1997) e Cleary (1999) bastaria classificar as firmas conforme seu desempenho ou status financeiro, cuja amostra consistiria de firmas com e sem dificuldades financeiras.

Utilizando uma estrutura financeira para examinar as divergências sobre a sensibilidade do investimento ao fluxo de caixa, Almeida e Campello (2002) desenvolveram uma teoria para explicar a relação entre investimento e fluxo de caixa quando as firmas enfrentam restrições ao crédito de forma quantitativa, ou seja, a restrição financeira estaria representada pelos valores dos recursos externos. Os autores alegam que se a capacidade por financiamento externo está positivamente relacionada com o valor de novos investimentos e as firmas são restritas ao crédito, então a sensibilidade do investimento ao fluxo de caixa aumentaria de acordo com a restrição financeira. Caso as firmas sejam não restritas, então o fluxo de caixa não seria significativo para explicar o investimento. Os resultados mostraram

\footnotetext{
${ }^{24}$ No caso de Kaplan e Zingales, as firmas foram classificadas com base em seu desempenho operacional. Já Cleary (1999) utilizou um índice (similar ao Altman's Z-factor) para identificar o status financeiro das firma.
} 
que os investimentos da firma e os recursos externos estão relacionados endogenamente, dessa forma, a sensibilidade do investimento ao fluxo de caixa aumentaria com a diminuição das restrições financeiras.

Moyen (2004) investigou se os resultados discordantes entre Fazzari et al. (1988) e Kaplan e Zingales (1997) devia-se à utilização de distintos critérios para o agrupamento das firmas. Por meio de uma simulação de dados, a autora gerou uma amostra de 2000 firmas durante 10 anos, dividida em grupos de acordo com cinco critérios: taxa de pagamentos de dividendos, fluxo de caixa, índice utilizado por Cleary (1999), modelo de firmas irrestritas e o modelo de firmas restritas ${ }^{25}$. As estimações mostraram que o critério de classificação realmente interferia no resultado da sensibilidade do investimento ao fluxo de caixa. Quando se considerou como critério o modelo de firmas restritas e o índice de Cleary (1999), firmas identificadas a priori como restritas financeiramente apresentaram baixa sensibilidade do investimento ao fluxo de caixa quando comparadas as firmas identificadas como irrestritas. Entretanto, firmas com baixa taxa de pagamento de dividendos classificadas a priori como restritas financeiramente exibiram alta sensibilidade do investimento ao fluxo de caixa. Frente aos resultados divergentes, a autora concluiu que não existe um critério único previamente definido para se identificar a presença da restrição financeira nas firmas, pois diferentes formas de classificação podem ocasionar diferentes conclusões.

Allayannis e Mozumbar (2004) investigaram se os resultados de Cleary (1999) deviam-se a inclusão de firmas com dificuldades financeiras na amostra ${ }^{26}$. Em um primeiro momento, utilizando uma amostra e metodologia similar ao realizado por Cleary (1999), mas excluindo as firmas com dificuldades financeiras, os autores evidenciaram que a sensibilidade do investimento ao fluxo de caixa era praticamente igual a todos os grupos de firmas consideradas restritas financeiramente. Já quando se considerava a amostra total, isto é, firmas com e sem dificuldades financeiras, o mesmo não pôde ser observado. Isso permitiu concluir que os resultados de Cleary (1999) eram afetados pela presença de firmas com dificuldades financeiras.

Complementando o trabalho de Allayannis e Mozumdar (2004), Baghat, Moyen e Suh (2005) analisaram se o comportamento do investimento de firmas com dificuldades

\footnotetext{
${ }^{25} \mathrm{O}$ modelo restrito era caracterizado pela escassez de acesso ao mercado externo e pela difícil escolha entre pagar dividendos ou investir na firma. Já o modelo irrestrito especificou as firmas com perfeito acesso ao mercado de capitais, cuja decisão de investimento e de financiamento não estava condicionada a restrição de capital.

${ }^{26}$ Financial distressed firms (firmas com dificuldades financeiras) são aquelas que apresentam fundos internos negativos, ou seja, não dispõem de fundos internos para a realização de investimentos tendo que, necessariamente, recorrer ao crédito externo.
} 
financeiras difere do comportamento de firmas financeiramente mais saudáveis. Os autores dividiram a amostra de firmas com dificuldades financeiras em dois grupos de acordo com o desempenho operacional, isto é, firmas com lucro operacional e firmas com perdas operacionais. Os resultados mostraram que as firmas com dificuldades financeiras e com lucro operacional no período exibiram sensibilidade positiva do investimento ao fluxo de caixa, resultado similar ao de firmas financeiramente saudáveis. Isso permitiu que o comportamento dos investimentos dessas firmas fosse interpretado da maneira equivalente ao de firmas financeiramente saudáveis. Já as firmas com dificuldades financeiras e com perdas operacionais apresentaram sensibilidade negativa do investimento ao fluxo de caixa. Os autores explicaram que este comportamento devia-se a continuação das atividades da firma que, mesmo com dificuldades financeiras e com perdas operacionais, continuavam investindo na esperança de obter melhor desempenho operacional no futuro.

Com uma amostra em dados em painel não balanceado de sete países desenvolvidos no período de 1987 a 1997, Cleary (2006) analisou as relações entre as medidas de restrição financeira mais utilizadas na literatura (isto é, taxa de pagamento de dividendos, tamanho e status financeiro da firma) e, com isso, pôde analisar quais as principais características das firmas restritas. A análise consistiu em examinar a composição dos grupos de firmas restritas financeiramente considerando características utilizadas para a construção dos outros grupos de firmas restritas. Por exemplo, firmas com alto pagamento de dividendos possuem maior porcentagem de firmas grandes e de firmas com alto status financeiro do que as firmas com baixo pagamento de dividendos. As estimativas mostraram que firmas grandes e firmas com alto pagamento de dividendos possuem maior sensibilidade do investimento ao fluxo de caixa do que firmas pequenas e com reduzido pagamento de dividendos. Os resultados também mostraram que firmas com alto risco financeiro, medido pela volatilidade do fluxo de caixa ${ }^{27}$, apresentaram baixa sensibilidade do investimento ao fluxo de caixa.

Com o objetivo de distinguir entre oportunidades futuras de investimento e restrição financeira, Carpenter e Guariglia (2008) introduziram uma nova proxy para controlar as oportunidades futuras de investimento que não seriam captadas pelo $q$ de Tobin usual. Essa nova proxy foi construída com base no número de obrigações contratuais com projetos futuros de investimento. Para estimar a relação entre fluxo de caixa e investimento, os autores consideraram uma amostra de 693 firmas britânicas no período de 1983 a 2000 classificandoa conforme seu tamanho, medido pelo número de empregados contratados pela firma. Os

\footnotetext{
${ }^{27}$ Considerada uma proxy para risco empresarial e financeiro, a volatilidade do fluxo de caixa é medida pela razão entre o desvio padrão e a média do fluxo de caixa.
} 
resultados mostraram que quando se considerava o $q$ de Tobin e os gastos contratuais para possíveis investimentos futuros, o poder da variável fluxo de caixa diminuía para firmas grandes, mas não se alterava para firmas pequenas. Isso sugeriu que enquanto o fluxo de caixa pode conter informações não capturadas pelo $q$ de Tobin, a sua significância nas equações do investimento é importante para capturar os efeitos da restrição financeira.

Kalatzis, Azzoni e Achcar (2008) analisaram o papel da restrição financeira sobre a decisão de investimento de um painel com 497 firmas brasileiras no período de 1986 a 1997, classificando as firmas conforme a sua intensidade de capital. Por meio da utilização de uma versão do modelo acelerador de investimento, estimada pelo método de efeito fixo com o uso de variáveis instrumentais, a estimativa mostrou que a variável de liquidez foi significante para ambos os grupos. No entanto, para as firmas consideradas mais intensivas em capital, o coeficiente mostrou-se maior em relação ao outro grupo, indicando que o investimento dessas firmas seria mais sensível à disponibilidade de fundos internos. Embora a variável de liquidez possa ser considerada uma proxy para restrições financeiras, ela também pode indicar o potencial de lucratividade futura das firmas. Para excluir essa possibilidade da análise, os autores consideraram os indicadores de rentabilidade combinado com o maior valor do coeficiente do fluxo de caixa, e concluíram que a variável de liquidez realmente estava atuando como uma proxy para restrição financeira, portanto, firmas mais intensivas de capital sofreriam maiores níveis de restrições financeiras.

Com a mesma base de dados, Kalatzis e Azzoni (2009) adotaram um procedimento bayesiano para a estimação do modelo de investimento. Os autores agruparam as firmas conforme a intensidade de capital e consideraram a introdução de duas variáveis de interação: uma em relação ao efeito específico da firma e o efeito temporal, e a outra, relacionando a variável fluxo de caixa com o efeito específico da firma. Teoricamente, a introdução da primeira variável de interação tem o objetivo de verificar se o comportamento do investimento varia ao longo do tempo e são diferentes entre as firmas no mesmo momento. Já a segunda variável de interação, analisa se os efeitos específicos da firma, como a habilidade gestorial, afetam as decisões de investimento das firmas. O principal resultado obtido na estimação está relacionado com o modelo que considera a inclusão da variável de interação entre o fluxo de caixa e o efeito específico da firma. Firmas mais intensivas de capital estariam mais sujeitas a restrições financeiras. Este resultado confirma a expectativa teórica já que firmas com maior intensidade de capital tenderiam a apresentar reduzida rentabilidade devido a presença de custos elevados. 
Como a literatura propõe críticas à análise da sensibilidade do investimento ao fluxo de caixa, Almeida, Campello e Weisbach (2004) propuseram-se a identificar a presença de restrição financeira analisando as variações nos níveis de saldo de caixa das firmas, já que estas variações poderiam estar relacionadas com as decisões de investimento. Os autores definiram uma firma restrita financeiramente como aquela que poupa mais caixa. Isso estaria relacionado ao fato de que as dificuldades de obtenção de crédito e os custos elevados dos fundos externos levariam a firma a poupar caixa. Dessa forma, firmas com dificuldades de obtenção de financiamento no mercado externo e firmas com dificuldades financeiras seriam consideradas restritas financeiramente de acordo com seu nível de saldo de caixa. Deste modo, caberia as firmas restritas financeiramente escolherem seu nível ótimo de saldo de caixa, ou seja, o ponto que possibilitaria poupar, investir e lucrar. Segundo esse conceito, Almeida et al. (2004) analisaram a sensibilidade do caixa ao fluxo de caixa baseando-se em uma amostra de firmas no período de 1971-2000. Os autores dividiram a amostra em grupos para identificar as firmas com maior probabilidade de restrição financeira, sendo eles: política de pagamento de dividendos, tamanho da firma, bond rating, commercial paper rating e o índice KZ desenvolvido por Lamont, Polk e Saá-Requejo (2001). Para todos os grupos, exceto para o agrupamento pelo índice $\mathrm{KZ}$, as firmas consideradas restritas financeiramente pagavam menos dividendos, possuíam tamanho menor em relação às firmas irrestritas e não tinham bond rating e commercial papers. O resultado das estimativas mostrou que firmas restritas apresentaram maiores níveis de saldo de caixa e maior volatilidade do saldo de caixa. Além disso, para o grupo de firmas consideradas restritas financeiramente, a sensibilidade do caixa ao fluxo de caixa apresentou-se significativo, positivo e diferente de zero. Já para as firmas não restritas, a sensibilidade do caixa ao fluxo de caixa apresentou-se não significativo e diferente de zero. A análise realizada por Almeida, Campello e Weisbach (2004) sugeriu que a sensibilidade do caixa ao fluxo de caixa é uma medida útil, correlacionada com a habilidade do acesso o mercado de capitais.

Arachya, Almeida e Campello (2007) estudaram as firmas que possuíam oportunidades lucrativas de investimento, mas que enfrentavam dificuldades para captar recursos no mercado externo para a realização de seus investimentos. Frente a esse tipo de obstáculo, as firmas tenderiam a poupar fundos internos ou a adquirir novas dívidas para aumentar seu saldo de caixa e realizar seus investimentos. Entretanto, altos níveis de saldo de caixa e a maior capacidade de endividamento aumentam a probabilidade de restrição financeira da firma e, portanto, afetam a capacidade da firma investir futuramente. Os efeitos diferenciados do caixa e da capacidade de endividamento sobre o investimento permitem 
testar como as firmas distribuem seu fluxo de caixa entre poupar caixa e saldar dívidas, de forma a obter um ponto ótimo de equilíbrio nessa distribuição.

Dessa forma, baseando-se em uma amostra de firmas no período de 1976 a 2001 e agrupando-a com os mesmos critérios utilizados por Almeida et al. (2004), exceto pelo índice KZ, Arachya et al. (2007) analisaram como a diferença entre a capacidade de endividamento e o potencial para poupar caixa (hedging needs) afetaria a probabilidade de restrição financeira das firmas. Para identificar essa diferença, os autores examinaram a relação entre o fluxo de caixa operacional e o $q$ de Tobin que atua como uma proxy para as oportunidades futuras de investimento. Seus resultados mostraram que firmas restritas preferem poupar caixa quando a diferença entre a capacidade de endividamento e o potencial para poupar caixa for grande, ou seja, quando a correlação entre o fluxo de caixa e as oportunidades de investimento for baixa. Caso a correlação seja alta (pequena diferença), então as firmas restritas teriam um maior beneficio ao poupar fluxo de caixa livre para a redução da dívida, acumulando capacidade de endividamento futura.

Investigando porque o saldo de caixa é mais importante para as firmas restritas, Denis e Sibilkov (2010) utilizaram um sistema de equações simultâneas para analisar a relação entre grandes saldos de caixa e elevados montantes de investimentos. Os autores classificaram a amostra de acordo com quatro critérios para identificar a presença da restrição financeira: taxa de pagamento de dividendos, tamanho da firma, dívida de curto (paper rating) e longo prazo (debt rating). Os resultados mostraram que para as firmas consideradas restritas financeiramente e com necessidades de financiamento, a grande disponibilidade de saldo de caixa estaria associada positivamente a altos níveis de investimento. Entretanto, algumas firmas restritas apresentaram reduzido saldo de caixa, o que, segundo os autores, poderia ser causado por três possíveis motivos: (1) o baixo saldo de caixa é resultado de potenciais problemas de agência, (2) essas firmas são impedidas de poupar caixa devido ao pagamento de altas taxas de juros, e (3) o custo de financiamento externo é mais caro além de ser distinto entre firmas consideradas restritas financeiramente.

Os estudos citados acima e vários outros têm tentado encontrar uma metodologia para identificar e agrupar a amostra considerando características em comum entre as firmas de forma a identificar a presença de restrição financeira. No entanto, a discussão sobre o comportamento do investimento da firma na presença da restrição financeira continua intensa.

Recentes estudos têm introduzido mecanismos de governança corporativa para analisar a decisão de investimento, visto que a adoção de boas práticas de governança corporativa 
influencia o comportamento de investidores e credores no financiamento de novos projetos de investimento.

O interesse em estudar a influência da governança corporativa nas decisões de investimento iniciou-se com estudos que utilizaram a estrutura de propriedade das empresas como uma forma de classificá-las e identificar a presença de assimetria de informações entre investidores e gestores que, por conseqüência, influenciavam a captação de recursos no mercado externo.

Hadlock (1998) procurou analisar o comportamento do investimento das firmas por meio de duas possíveis interpretações para a sensibilidade do investimento ao fluxo de caixa. A primeira interpretação baseia-se na teoria desenvolvida por Myers e Majluf (1984), no qual o relacionamento entre liquidez e investimento seria um sintoma de sub-investimento (underinvestment hypothesis), isto é, firmas deixariam de realizar projetos de investimentos lucrativos devido à presença de assimetria de informação que elevaria o custo do financiamento externo. Já a segunda interpretação baseia-se na teoria do fluxo de caixa livre desenvolvida por Jensen (1986), no qual a diferença entre os custos internos e externos seria um sintoma de sobre-investimento (overinvestment hypothesis) que se deve a má utilização dos fundos internos, ou seja, gestores gastariam os fundos internos em projetos de investimento não lucrativos. Para a realização do estudo, Hadlock (1998) examinou se firmas que distribuíam direito de propriedade para os gestores diminuíam o risco do investimento em projetos não lucrativos, visto que a concessão de direitos de propriedade aos gestores é um mecanismo de governança corporativa que busca alinhar os interesses de gestores e acionistas. Com uma amostra de 435 firmas norte-americanas no período de 1973 a 1976, o autor agrupou a amostra em quartis, conforme a quantidade de direitos de propriedade dos gestores e estimou uma equação do investimento. As estimativas evidenciaram uma relação em forma de $\mathrm{U}$ invertida entre os direitos de propriedade dos gestores e a sensibilidade do investimento ao fluxo de caixa. Hadlock (1998) interpretou esta situação como um resultado consistente com a hipótese de underinvestment, causada pela presença de assimetria de informação.

Wei e Zhang (2008) utilizaram uma amostra de firmas de oito países asiáticos no período de 1993 a 1996 e realizaram o mesmo procedimento desenvolvido por Hadlock (1998), porém, evidenciaram resultados distintos. Os autores encontraram que a sensibilidade do investimento ao fluxo de caixa era reduzida com o aumento dos direitos de fluxo de caixa dos maiores acionistas. No entanto, a sensibilidade se elevava de acordo com o grau de divergência entre os direitos de controle e de fluxo de caixa dos maiores acionistas. Esses resultados são consistentes com a hipótese de sobre-investimento, causada pelos custos de 
agência do fluxo de caixa livre, mas inconsistente com a hipótese de sub-investimento, causada pelos problemas de assimetria de informação. Os autores explicam que uma possível razão para os resultados divergentes em relação a Hadlock (1998) deve-se a própria natureza das firmas inseridas na amostra. O estudo de Hadlock (1998) baseia-se em firmas norteamericanas, caracterizadas pela estrutura de propriedade dispersa, já a amostra de Wei e Zhang (2008) é caracterizada por firmas de países emergentes, que possuem um fraco mercado de capitais, fraca proteção aos acionistas minoritários e cuja propriedade e controle concentra-se entre poucos acionistas.

A grande disparidade entre direitos de controle e de propriedade e a fraca proteção legal aos investidores facilita o agrupamento de firmas via estrutura piramidal. Com a separação dos direitos de voto e de fluxo de caixa, a estrutura de propriedade por pirâmide permite ao maior acionista último o controle da firma sem a necessidade de adquirir grandes quantidades de ações, o que aumenta o risco de expropriação dos acionistas minoritários. Frente a essa discussão, para testar se um potencial conflito de interesse entre acionistas controladores e minoritários afeta a estrutura financeira da firma, Bianco e Casavola (1999) analisaram a disposição dos investidores em financiar firmas pertencentes a um grupo piramidal. Nesse sentido, os autores focaram em duas características mensuráveis: a posição da firma na estrutura piramidal e as oportunidades de transferências de recursos dentro do grupo pelo acionista controlador. Os resultados indicaram que os laços criados dentro da pirâmide diminuiriam a restrição financeira devido ao fluxo interno de capital gerado pelas movimentações financeiras dentro do grupo, ou seja, firmas associadas a uma estrutura de propriedade piramidal financiariam projetos de investimentos uma das outras, reduzindo a necessidade de recorrer ao financiamento externo.

Capenter e Rondi (2000) investigaram se o impacto da restrição financeira, ao limitar as oportunidades de investimentos, impede o crescimento de firmas italianas de pequeno e médio porte. Comparando o tamanho com a idade das firmas, os autores encontraram que muitas firmas pequenas também são maduras e, portanto, já tiveram oportunidades para construir um bom relacionamento com credores. Isso evidencia que adotar apenas o tamanho ou a idade das firmas não seria um bom critério para identificar a presença de restrição financeira. Dessa forma, os autores utilizaram a interação entre os grupos e dividiram a amostra entre firmas grandes e jovens, grandes e maduras, pequenas e jovens e pequenas e maduras. Além de tamanho e idade também se considerou a presença de estrutura piramidal nos grupos. Os resultados indicaram que firmas grandes, jovens e sem afiliação piramidal possuem uma alta sensibilidade do investimento ao fluxo de caixa. Isso estaria relacionado ao 
fato de que mesmo as firmas sendo grandes poderiam apresentar um fraco histórico de relacionamento com credores, o que dificultaria o acesso ao financiamento externo. Por outro lado, quando se considerou firmas com o mesmo tamanho e mesmo grupo de idade, firmas com estrutura de propriedade piramidal apresentaram baixa sensibilidade do investimento ao fluxo de caixa, indicando menor grau de restrição financeira do que aquelas não pertencentes aos grupos piramidais.

Com o objetivo de analisar a relação entre as políticas de manutenção de saldo de caixa e os mecanismos de governança corporativa, Chen e Chuang (2009) mostram que as políticas de manutenção de saldo de caixa irão depender das oportunidades de investimentos que a firma possui. Por exemplo, firmas do setor de alta tecnologia necessitam de acesso rápido e facilitado ao crédito para realizar seus investimentos e se manterem no mercado, dado que se trata de um setor altamente competitivo. Nesse sentido, essas firmas necessitam de elevados níveis de saldo de caixa que as possibilite realizar investimentos sem a inteira necessidade de recorrer ao capital externo. No entanto, conforme apontando por Ditmar et al. (2003), a manutenção de saldo de caixa pode permitir que gestores o utilizem em projetos não lucrativos e que não estariam relacionados aos interesses dos acionistas, gerando problemas de agência.

Gugler (2003) procurou analisar a ambigüidade na interpretação do fluxo de caixa como variável chave para indicar a presença de restrição financeira nas decisões de investimento. $\mathrm{O}$ autor utilizou informações de estrutura de propriedade e controle para explicar o papel do coeficiente do fluxo de caixa como variável determinante para explicar a presença de restrição financeira. $\mathrm{O}$ resultado indicou que diferentes categorias de controle, como por exemplo familiar, tenderiam a sofrer de maiores restrições financeira, apresentando maiores assimetrias de informação e maiores custos da agência. Por outro lado, empresas com uma estrutura de propriedade mais concentrada apresentaram menor sensibilidade do investimento ao fluxo de caixa.

Para analisar de que forma a sensibilidade do investimento ao fluxo de caixa estaria relacionada com problemas de agência, Crespi e Scellato (2007) examinaram a estrutura de propriedade e o papel desempenhado pelos intermediários financeiros nas decisões de investimento da firma. Os autores utilizaram de um banco de dados de 1035 firmas italianas no período de 1998 a 2003. Os resultados indicaram uma relação na forma de U invertida entre a concentração de propriedade e a sensibilidade do investimento ao fluxo de caixa. Assim como no trabalho de Hadlock (1998), o lado crescente desta relação foi interpretado como o indicativo da presença das imperfeições do mercado de capital. Neste caso, o 
alinhamento de interesses entre gestores e acionistas estaria relacionado a um aumento na concentração de propriedade, ou seja, os gestores aproveitariam melhor os recursos financiados externamente ao investir em projetos que realmente aumentassem o valor da firma e a satisfação dos investidores e, portanto, se observaria um aumento marginal na elasticidade do fluxo de caixa.

Com uma amostra de firmas francesas para os anos de 1998, 2000 e 2002, Ginglinger e Saddour (2007) analisaram se níveis elevados de saldo caixa estariam vinculados à presença de restrição financeira e como o nível de saldo de caixa estaria relacionado aos problemas de agência. Os autores classificaram a amostra de acordo com o tamanho das firmas e a taxa de pagamentos de dividendos. Para medir a qualidade da governança corporativa das firmas, os autores utilizaram o índice GIndex, desenvolvido por Gompers, Ishii e Metrick (2003). Suas estimativas mostraram que a adoção de políticas de proteção às ofertas hostis proporciona às firmas restritas uma fonte alternativa de flexibilidade, permitindo-lhes emitir ações sem a perda do controle acionário. Além disso, quando se considerou a estrutura de propriedade, firmas familiares mostraram-se mais restritas financeiramente do que as demais. Os autores também encontraram que firmas com fortes políticas de proteção aos direitos dos acionistas retêm mais caixa, o que é contrário ao previsto pela teoria de agência. Este resultado é, em parte, explicado pela relação positiva entre a qualidade da governança corporativa e o grau de restrição financeira da firma. Os autores ainda mostraram que a qualidade da governança corporativa não exerce impacto sobre os níveis de saldo de caixa de firmas irrestritas financeiramente, no entanto, para firmas restritas, a qualidade da governança corporativa está positivamente relacionada com o nível de saldo de caixa.

Já Andress (2008) estudando um painel com 264 firmas familiares alemãs no período de 1997 a 2004 obtiveram resultados contrários ao trabalho de Ginglinger e Saddour (2007). A suposição de que as firmas familiares seriam mais suscetíveis a restrição financeira não é encontrada por Andress (2008). Seus resultados mostraram que essas firmas são financeiramente mais estáveis quando comparadas com as firmas não familiares e com mesmo tamanho e igual taxa de pagamento de dividendos. Nesse caso, a análise da sensibilidade do investimento ao fluxo de caixa mostrou-se menos sensível à disponibilidade de fluxo de caixa, além do que, por serem firmas menos restritas suas decisões seriam mais ágeis para aproveitar as oportunidades de investimento.

Com uma amostra de 1872 firmas norte-americanas no período de 1993 a 2004, Harford et al. (2008) estudaram como problemas de agência influenciam os níveis de saldo de caixa acumulados pelas firmas. Para mensurar os problemas de agência, os autores adotaram 
mecanismos de governança corporativa, como por exemplo, concentração de propriedade, compensação dos gestores, composição do conselho de administração, e o índice GIndex, desenvolvido por Gompers, Ishii e Metrick (2003), que se baseia na quantidade de políticas de proteção aos direitos dos acionistas. Os autores encontraram que firmas com maior quantidade de acionistas insiders apresentaram maiores níveis de saldo de caixa, enquanto que firmas com fraca proteção aos acionistas apresentaram nível de saldo de caixa reduzido. Além disso, os autores também evidenciaram uma correlação negativa entre tamanho da firma e sua qualidade de governança, isto é, firmas com fracas práticas de governança corporativa são significantemente maiores do que as firmas com boas práticas de governança corporativa.

A transparência é o principal mecanismo de governança corporativa que enseja o acesso ao financiamento, pois é a melhor forma dos acionistas conhecerem a real situação financeira da firma. Sob as implicações dos problemas de agência no funcionamento da firma, Chae, Kim e Lee (2009) investigaram os efeitos da governança corporativa na política de pagamento de dividendos e o seu papel na restrição financeira. Embora fosse esperado que o pagamento de dividendos reduzisse a disponibilidade de fluxo de caixa livre a serem gastos em projetos não lucrativos, os autores encontraram que o pagamento de dividendos está relacionado com o aperfeiçoamento das práticas de governança corporativa.

Relacionando o acesso ao crédito externo antes e depois de mudanças na estrutura de propriedade, ou seja, sob o contexto das privatizações de firmas, Knyazeva, Knyazeva e Stiglitz (2009) examinaram se a restrição financeira antes da firma ser privatizada interferiria no seu desempenho após a privatização. As estimações evidenciaram que firmas com restrições financeiras antes de serem privatizadas investiram mais depois da mudança da natureza da propriedade - isto é, depois da privatização. Indústrias restritas financeiramente antes do processo de privatização tiveram um crescimento mais rápido quando foram privatizadas do que aquelas consideradas não restritas financeiramente, além de uma redução no grau da restrição financeira.

Com uma amostra de 6867 firmas no período de 1998 a 2005, Tong (2009) analisou se a diversificação da firma contribuía para aumentar o valor do saldo de caixa das firmas restritas financeiramente por meio da eficiência do mercado interno de capitais, ou contribuía para reduzir o valor do saldo de caixa devido aos custos de agência ${ }^{28}$. A amostra foi dividida

\footnotetext{
${ }^{28}$ Quando se denota aumento (redução) no valor do saldo de caixa, espera-se que a cada $\$ 1,00$ poupado represente um montante final de, por exemplo, $\$ 1,10(\$ 0,90)$.
} 
de acordo com o pagamento de dividendos e com a avaliação do crédito (credit rating) ${ }^{29}$. Para examinar o impacto de problemas de agência sobre o valor do saldo de caixa das firmas diversificadas inseriu-se medidas de governança corporativa. $O$ autor encontrou que a diversificação da firma reduz o valor de caixa tanto para as firmas diversificadas consideradas restritas quanto para as não restritas financeiramente. Além disso, o autor também evidenciou que a diversificação da firma possui um impacto negativo (nulo) sobre o valor do caixa das firmas que adotam menor (maior) número de mecanismos de governança corporativa.

No Brasil há uma enorme carência de estudos que tratam da relação entre decisões de investimento e restrição financeira. Quando se introduz aspectos de governança corporativa para analisar essa relação, os estudos internacionais são ainda mais escassos e inexistentes para a economia brasileira. Com o aumento significativo de firmas que adotaram práticas de governança corporativa nos últimos anos, torna-se imprescindível investigar a relação entre tais práticas e a presença de restrição financeira nas decisões de investimento. Desta forma, este estudo visa contribuir para essa escassa literatura, analisando como a adoção de boas práticas de governança corporativa influenciam a probabilidade de restrição financeira das firmas. Por conseguinte, este estudo também investiga o papel da governança corporativa nas decisões de investimento das firmas na presença da restrição financeira, utilizando como critério de classificação da amostra o índice $\mathrm{KZ}$ proposto na literatura.

\footnotetext{
${ }^{29}$ Segundo Tong (2008), firmas com crédito avaliado (credit rating) possuem melhor acesso ao mercado de dívida pública, obtendo, com maior facilidade, fundos externos para a realização de seus investimentos.
} 


\section{Dados e Modelos Econométricos.}

Este capítulo tem por objetivo apresentar e descrever o banco de dados utilizado neste estudo, além de enunciar os modelos econométricos e seus respectivos métodos de estimação adotados para analisar a relação entre governança corporativa, restrição financeira e decisão de investimento das firmas.

A seção 4.1 descreverá o banco de dados e as variáveis utilizadas no trabalho, relatando a construção das variáveis de governança corporativa e os indicadores financeiros. Já a seção 4.2 apresentará os modelos e seus métodos de estimação. Os modelos utilizados neste estudo são: o modelo probabilístico logit para dados em painel estimado por efeito aleatório; e, o modelo de investimento, também aplicado para dados em painel, estimado pelo Método dos Momentos Generalizados (GMM). Além disso, nesta seção, se discutirá sobre os testes de autocorrelação serial e o teste de Sargan, envolvidos na estimação pelo GMM.

\subsection{Banco de Dados}

Nesta seção será apresentado os dados utilizados para a realização deste trabalho. O banco de dados adotado para o estudo é proeminente do Economatica, do site da BM\&FBOVESPA e do relatório Informativo Anual (IAN) ${ }^{30}$. Dados sobre tipos e quantidade de ações emitidas, quantidade de ações dos maiores acionistas, acordo entre acionistas, natureza dos maiores acionistas, dentre outras informações foram coletadas no IAN. Dados financeiros foram coletados no Economatica e os dados sobre a adesão das firmas aos Níveis Diferenciados de Governança Corporativa foram coletados no site da BM\&FBOVESPA. Firmas com dados sobre estrutura de propriedade incompletos, dados inconsistentes e firmas financeiras foram excluídas. Para incluir o maior número possível de informação, foi utilizado um painel não balanceado que totalizou 500 firmas brasileiras no período de 1997 a 2007. Todas as informações contidas neste banco de dados foram deflacionadas de acordo com o Índice de Preços ao Consumidor Amplo (IPCA) calculado pelo Instituto Brasileiro de Geografia e Estatística (IBGE). As variáveis utilizadas no estudo estão descritas na subseção que se segue.

\footnotetext{
${ }^{30} \mathrm{O}$ relatório Informativo Anual (IAN) faz parte de um dos três relatórios exigidos pela Comissão de Valores Mobiliários (CVM) às firmas de capital aberto.
} 


\subsubsection{Construção das Variáveis}

Como o intuito do trabalho é investigar como os mecanismos de governança corporativa podem influenciar nas decisões de investimento das firmas, as principais variáveis relacionadas a governança corporativa utilizadas foram: a natureza do maior acionista último e se este é o acionista controlador da firma, a presença do maior acionista último no conselho de administração e na direção da firma, a adesão a um dos níveis diferenciados de governança corporativa da BM\&FBOVESPA, o percentual de direito de voto e de fluxo de caixa do maior acionista último, além da estrutura de propriedade piramidal.

$\mathrm{O}$ acionista controlador da firma é definido sobre as ações que concedem direito ao voto, e a estrutura de propriedade é baseada nas ações que concedem direito de propriedade. No caso do Brasil, ações que por lei concedem direito de voto são as ações ON e as ações que concedem direito de propriedade, são as ações $\mathrm{PN}^{32}$. O cálculo dos direitos de voto e direitos de fluxo de caixa (direito de propriedade) de cada acionista depende da estrutura de propriedade da firma que pode ser direta ou piramidal (indireta). Define-se uma estrutura de propriedade piramidal como o conjunto de firmas legalmente independentes controladas pelo mesmo acionista (líder do grupo), no qual existe pelo menos uma firma intermediária entre o acionista controlador e a última firma. Essa estrutura permite a este acionista controlar as firmas dentro do grupo piramidal com uma pequena parcela de capital social, permitindo assim, uma discrepância entre direitos de voto e direitos de fluxo de caixa (BIANCO e CASAVOLA, 1999).

Dessa forma, se a firma não pertence a um esquema piramidal, os direitos de fluxo de caixa e direitos de voto são determinados diretamente pela fração total de capital social e capital votante possuídos pelo acionista. No entanto, caso a firma pertença a um esquema piramidal, os direitos de fluxo de caixa de cada acionista são calculados pelo produto dos direitos de fluxo de caixa, possuídos por este acionista, em cada firma inserida na estrutura piramidal. Já para o cálculo do direito de voto, deve-se primeiramente investigar se o acionista analisado é o acionista controlador da estrutura piramidal.

La Porta et al. (1999), Claessens et al. (2000), e Faccio e Lang (2002) adotaram o limitante de $20 \%$ de direito ao voto para definir um acionista como o controlador, enquanto que Wei e Zhang (2008) consideraram como acionista controlador quem detivesse mais do que $50 \%$ de direito de voto por meio de uma estrutura direta de propriedade ou por uma

\footnotetext{
${ }^{32}$ As ações PN também concedem direito ao voto. Entretanto, isso depende da distribuição de propriedade e controle de cada firma, não sendo obrigatório por lei.
} 
estrutura de propriedade piramidal. A definição de Wei e Zhang (2008) corrobora com a definição dada pelo Código das Melhores Práticas de Governança Corporativa (2009) e, por este motivo, considerou-se como acionista controlador aquele que detivesse mais do que $50 \%$ dos direitos de voto da firma. Entretanto, para se definir o acionista controlador da estrutura de propriedade piramidal, ainda necessita-se definir quem é o maior acionista último da firma.

Um acionista é considerado o maior acionista último se ele possuir o maior percentual de direito de voto, direta ou indiretamente, em relação a todos os demais acionistas da firma. Assim, dada a definição de acionista controlador, pode-se concluir que existem maiores acionistas últimos que também são acionistas controladores. Considerando a estrutura de propriedade indireta, se o maior acionista último da estrutura de propriedade piramidal também detiver mais do que $50 \%$ de direito de voto em cada firma dentro da pirâmide, este será denominado acionista controlador da estrutura de pirâmide. Dessa forma, se o maior acionista último também for o acionista controlador, sua fração de direito de voto será determinada pela porcentagem de capital votante que a penúltima firma possuir sobre a última firma pertencente à pirâmide. Caso o maior acionista último não seja o acionista controlador, o acionista controlador da estrutura piramidal será aquele que detiver mais do que $50 \%$ de direito de voto ao se calcular o produto das porcentagens de direito de voto em cada firma ao longo da estrutura.

A identificação do maior acionista último como acionista controlador possibilitou a construção da variável controle que assume valor igual a 1 se o maior acionista último for o acionista controlador, e zero, caso contrário. Pela própria construção da variável controle, pôde-se identificar a natureza do controle da firma a partir da natureza do maior acionista último.

A natureza do maior acionista último pode ser classificada de acordo com sua identidade, isto é: acordo entre acionistas, famílias, Estado, estrangeiras, institucionais e outras. A categoria "acordo entre acionistas" representa as firmas cujo maior acionista último é caracterizado por um "bloco" de acionistas unidos por um contrato legal, no qual todas as estratégias financeiras da firma são decididas por todos os membros do bloco. A categoria "familiar" representa as firmas cujo maior acionista último é caracterizado por uma família ou por um indivíduo. Já a categoria "estrangeira" representa os maiores acionistas últimos que são estrangeiros. A categoria "institucionais" contempla investidores institucionais: fundos de pensão e fundos de investimento, conforme proposto pelo Código de Melhores Práticas de Governança Corporativa - IBGE (2009). A categoria “outros" compreende cooperativas, fundações e firmas S.As de capital fechado. Firmas cujo maior acionista último seja o Estado 
foram classificadas em uma categoria específica, pois são firmas com propriedade concentrada em posse do Estado, que as utilizam para alcançar objetivos políticos, entretanto, quem paga por eventuais perdas são os cidadãos (Shleifer e Vishny, 1994).

Com as porcentagens de direito de voto e de propriedade do maior acionista último calculadas, pôde-se criar as variáveis dirfc e dirvoto, que correspondem, respectivamente, ao percentual de direito de fluxo de caixa e ao percentual de direito de voto deste acionista. Isso também permitiu criar a variável desvio, definida como a diferença entre os direitos de voto e de fluxo de caixa do maior acionista último.

Além das variáveis citadas acima, as variáveis binárias pirâmide, nivelgc, conselho e diretor também foram criadas. A variável pirâmide assume valor igual a 1 caso a firma pertença a uma estrutura de propriedade piramidal, e valor zero, caso contrário. A variável nivelgc identifica se a firma está inserida em um dos níveis diferenciados de governança corporativa da BM\&FBOVESPA (Nível 1 ou Nível 2) ou no Novo Mercado. Dessa forma, esta variável assume valor 1 se a firma estiver inserida em um dos segmentos de listagem da BM\&FBOVESPA, e zero, caso contrário. Já as variáveis conselho e diretor são variáveis binárias relacionadas a participação do maior acionista último como membro do conselho de administração e como diretor da firma, respectivamente. Além disso, observando que grande parte dos maiores acionistas últimos que participavam da direção da firma também eram membros do conselho de administração, foi construída a variável binária $C D$ que assume valor 1 se o maior acionista último for membro do conselho e atuar simultaneamente na direção da firma; e zero, caso contrário. Um quadro sintético com a definição das variáveis utilizadas neste estudo, assim como a tabela de correlação entre estas variáveis, está disponibilizado no apêndice A.

Com as variáveis do estudo definidas, resta apenas apresentar a construção da variável binária $K Z$ que discrimina entre as firmas consideradas restritas e não restritas financeiramente de acordo com o índice KZ. Este índice, construído por Lamont, Polk e SaáRequejo (2001), consiste de variáveis estritamente relacionadas à restrição financeira e ordena as firmas pelo grau de restrição financeira. Este índice é dado por:

$$
\text { Índice } K Z_{i t}=-\left(1,001909 \cdot \frac{F C}{K_{t-1}}\right)_{i t}+(0,2826389 \cdot Q)+\left(3,139193 \cdot \frac{D}{C T_{t}}\right)-\left(39,3678 \cdot \frac{\text { Div }}{K_{t-1}}\right)-\left(1.314759 \cdot \frac{\text { Caixa }}{K_{t-1}}\right)
$$


em que $t$ é o ano, variando de 1 até T; $i$ é a firma, variando de 1 até $\mathrm{N} ; K_{i t}$ é o estoque de capital; $F C_{i t}$ é o fluxo de caixa; $Q_{i t}$ é a variável $q$ de Tobin; $D_{i t}$ é a variável dívida total; $C T_{i t}$ é o capital total; Div ${ }_{i t}$ são os gastos com dividendos e Caixa $_{i t}$ é dado pela soma do caixa e dos investimentos de curto prazo.

Desta forma, assumiu-se a mediana do índice $\mathrm{KZ}$ como ponto de corte para classificar as firmas como restritas e não restritas financeiramente. As firmas que apresentaram índice $\mathrm{KZ}$ maior do que a mediana foram consideradas restritas financeiramente, e as firmas com índice $\mathrm{KZ}$ inferior a mediana foram consideradas não restritas financeiramente. Por meio deste agrupamento, a variável binária $K Z$ foi construída, assumindo valor igual a 1 se a firma pertencer ao grupo de firmas consideradas restritas e 0 , caso a firma pertença ao grupo de firmas consideradas não restritas financeiramente. Com a situação financeira da firma definida pela variável binária $K Z$, torna-se interessante analisar quais características da firma podem ser determinantes para contribuir na acentuação do grau de restrição financeira das mesmas.

Na próxima seção será discutido os modelos econométricos utilizados, juntamente com seus respectivos métodos de estimação.

\subsection{Modelos Econométricos para Dados em Painel}

Esta seção tem por objetivo apresentar e discutir os modelos econométricos utilizados e seus respectivos métodos de estimação. Primeiramente, como o intuito do estudo é analisar como os mecanismos de governança corporativa e características financeiras das firmas podem influenciar na probabilidade da firma ser considerada restrita financeiramente ou não, um modelo probabilístico logit para dados em painel foi utilizado. Em um segundo momento, empregou-se um modelo de investimento para dados em painel, estimado pelo Método dos Momentos Generalizados (GMM), para analisar como mecanismos de governança corporativa influenciam na taxa de investimento de firmas consideradas restritas e não restritas financeiramente.

Modelos probabilísticos são utilizados quando há o propósito de se analisar o efeito que cada variável pode causar sobre a probabilidade de o evento investigado ocorrer. Estes modelos são aplicáveis quando a variável dependente é uma variável binária que assume valor igual a 1 caso o evento de interesse ocorra para o indivíduo $i$ no período $t$, ou assume, caso contrário, valor igual a zero. Isso significa escrever um modelo de regressão linear tal como: 


$$
y_{i t}=\alpha_{i}+X_{\mathrm{it}}^{\prime} \beta+\varepsilon_{i t}
$$

com

$$
E\left(y_{i t} \mid X_{i t}, \alpha_{i}\right)=\alpha_{i}+X_{i t}^{\prime} \beta
$$

em que é $t$ é o ano, variando de 1 até T; $i$ é a firma, variando de 1 até $\mathrm{N} ; y_{i t}$ é a variável dependente binária que, no caso em estudo, assume valor 1 se a firma for considerada restrita financeiramente pelo índice KZ, e zero, caso contrário; $\alpha_{i}$ é o efeito específico da firma; $X_{i t}$ é uma matriz que representa as variáveis explicativas do modelo; $\beta$ é um vetor de parâmetros desconhecidos e, $\varepsilon_{i t}$ é o termo de erro.

Como a variável dependente é binária, se assumirmos $p_{i t}$ como a probabilidade da firma $i$ ser considerada restrita financeiramente no período $t$, teremos que:

$$
\begin{aligned}
E\left(y_{i t} \mid X_{i t}, \alpha_{i}\right) & =E\left(y_{i t}=1 \mid X_{i t}, \alpha_{i}\right) \cdot p_{i t}+E\left(y_{i t}=0 \mid X_{i t}, \alpha_{i}\right) \cdot\left(1-p_{i t}\right) \\
& =1 \cdot p_{i t}+0 \cdot\left(1-p_{i t}\right) \cdot p_{i t}=p_{i t}
\end{aligned}
$$

Esta probabilidade geralmente é modelada como uma função de variáveis explicativas, sendo:

$$
p_{i t}=E\left(y_{i t} \mid X_{i t}, \alpha_{i}\right)=\operatorname{Pr}\left[y_{i t}=1 \mid X_{i t}, \alpha_{i}\right]=F\left(\alpha_{i}+X_{i t}^{\prime} \beta\right)
$$

em que $F(\cdot)$ é simétrica no ponto zero ${ }^{34}$.

Desta forma, como em (3) assume-se $E\left(y_{i t} \mid X_{i t}, \alpha_{i}\right)=\alpha_{i}+X_{i t}^{\prime} \beta$, e em (5) temos que $E\left(y_{i t} \mid X_{i t}, \alpha_{i}\right)=F\left(\alpha_{i}+X_{i t}^{\prime} \beta\right)$, conclui-se que $F\left(\alpha_{i}+X_{i t}^{\prime} \beta\right)=\alpha_{i}+X_{i t}^{\prime} \beta$ e, portanto, a função $F(\cdot)$ pode assumir valores não pertencentes ao intervalo $[0,1]$. Além disso, como $y_{i t}$ não é contínua, assumindo apenas dois valores, $y_{\text {it }}$ possui distribuição de probabilidade binomial, cuja variância condicionada a $X_{i t}$ é:

\footnotetext{
${ }^{34}$ Uma função é dita simétrica no ponto zero quando $F(x)=F(-x)$ para todo $x$.
} 


$$
\operatorname{Var}\left(y_{i t} \mid X_{i t}\right)=p_{i t} \cdot\left[1-p_{i t}\right]
$$

Em conseqüência disso, $\varepsilon_{i t}$ não possui distribuição normal, o que significa que, com exceção do caso em que a probabilidade de resposta independa de qualquer uma das variáveis explicativas, existe problema de heteroscedasticidade no modelo de probabilidade linear.

Uma solução padrão para se corrigir o problema de heteroscedasticidade e limitar $F\left(\alpha_{i}+X_{i t}^{\prime} \beta\right)$ para um intervalo unitário é utilizar uma função contínua. Várias funções nãolineares têm sido sugeridas para a função $F$, sendo as funções logística e normal-padrão as mais adotadas pela literatura. Quando se utiliza a função logística ${ }^{35}$, o modelo é nomeado modelo probabilístico logit. Já quando a função normal-padrão é adotada, o modelo é denominado modelo probabilístico probit. Estes modelos derivam de uma variável latente ou não observada que pode ser descrita por:

$$
y_{i t}=\left\{\begin{array}{l}
1, \text { se } y_{i t}^{*}>0 \\
0, \text { se } y_{i t}^{*} \leq 0
\end{array} \quad, \quad \text { em que } y_{i t}^{*}=\alpha_{i}+X_{i t}^{\prime} \beta+\varepsilon_{i t}\right.
$$

Como $y_{i t}^{*}$ é uma variável contínua, temos que:

$$
\begin{aligned}
p_{i t}(x) & =\operatorname{Pr}\left[y_{i t}=1 \mid X_{i t}, \alpha_{i}\right]=\operatorname{Pr}\left[y_{i t}^{*}>0 \mid X_{i t}, \alpha_{i}\right] \\
& =\operatorname{Pr}\left[\varepsilon_{i t}>-\alpha_{i}-X_{i t}^{\prime} \beta \mid X_{i t}, \alpha_{i}\right] \\
& =F\left(\varepsilon_{i t}>-\alpha_{i}-X_{i t}^{\prime} \beta\right) \\
& =1-F\left(-\left(\alpha_{i}+X_{i t}^{\prime} \beta\right)\right) \\
& =F\left(\alpha_{i}+X_{i t}^{\prime} \beta\right)
\end{aligned}
$$

Portanto, o uso da função logística ou da função normal-padrão irá corrigir o problema de não normalidade em $\varepsilon_{i t}$, além de fazer com que $F(\cdot)$ assuma valores estritamente entre zero e um.

Em relação a interpretação dos resultados obtidos pela estimação do modelo logit ou do modelo probit, cabe ressaltar que a magnitude das mudanças na probabilidade de sucesso,

${ }^{35}$ A função logística é dada por: $F\left(X_{i t}^{\prime} \beta\right)=\frac{\exp \left(X_{i t}^{\prime} \beta\right)}{\left[1+\exp \left(X_{i t}^{\prime} \beta\right)\right]}$ 
isto é, $y_{i t}=1$, dada uma alteração em $x_{i t}$, mantendo fixo os demais fatores, é determinada por $\beta_{j}$ e pela magnitude de $f\left(\alpha_{i}+X_{j t}^{\prime} \beta\right)$, pois:

$$
\frac{\partial p_{i t}(x)}{\partial x_{j i, t}}=\beta_{j} f\left(\alpha_{i}+X_{j t}^{\prime} \beta\right)
$$

em que $f$ é a função densidade de probabilidade ${ }^{36}$. Visto que $f(\cdot)$ é uma função positiva, isso permite concluir que o parâmetro $\beta_{j}$ nos fornece a informação se a variável explicativa possui um impacto positivo ou negativo sobre a probabilidade de resposta. Com isso, temos que, na prática, considerar o uso do modelo logit ou do modelo probit é indiferente. Ambos os modelos produzirão resultados semelhantes, principalmente, se considerarmos que o fundamental interesse do modelo logit e probit é analisar o impacto (sinal) causado pelas variáveis explicativas sobre a variável binária. Desta forma, dado que os dois modelos produzem resultados semelhantes, neste estudo adotou-se o modelo probabilístico logit.

O modelo probabilístico logit para dados em painel pode ser estimado de duas formas: por efeito fixo ou por efeito aleatório. Se considerarmos a estimação por efeito fixo, $\alpha_{i}$ será tratada como uma característica específica de $i$ que não é observada, admitindo-se sua correlação com as demais covariadas do modelo. Neste caso, como a variável dependente é binária e necessita-se eliminar o efeito específico do modelo, serão consideradas na estimação apenas as firmas que mudaram seu status de um período para outro. Isso conduz a perda das observações onde $y_{i t}=0$ para todo $t$ ou $y_{i t}=1$ para todo $t$, ocasionando a perda de observações cuja informação não varie no tempo. Já se considerarmos a estimação por efeito aleatório, esta admite o efeito específico da firma como uma variável aleatória não observada sem correlação com as demais covariadas, o que a permite ser incorporada ao resíduo do modelo.

Portanto, com o intuito de considerar o maior número possível de observações no modelo estimado, adotar-se-á no estudo a estimação por efeito aleatório, visto que a estimação do modelo logit pelo efeito fixo é muito menos precisa e exclui informações que não variem no tempo ${ }^{37}$. De acordo com Cameron e Trivedi (2010, p. 629): "The fixed-effect

\footnotetext{
${ }^{36}$ A função densidade de probabilidade $(f)$ é a derivada da função acumulada $(F)$ no ponto.

${ }^{37}$ Como no estudo se utiliza variáveis binárias relativas às características de governança corporativa das firmas e que, normalmente, não são modificadas de um período para outro, a estimação do modelo probabilístico logit por efeito fixo elimina muitas observações na estimação. Ao se estimar o modelo em (10) por efeito fixo temos a eliminação de 55,6\% das observações e de 209 firmas.
} 
estimates are much less precise, differ considerably from the other estimates, and are available only for time-varying regressors".

Dadas as considerações a respeito do modelo probabilístico logit, o modelo adotado neste trabalho possui, como já ressaltado, uma variável dependente binária construída a partir do índice KZ. Como é de interesse testar a influência de características de governança corporativa sobre a probabilidade de a firma ser considerada restrita financeiramente, o modelo a ser estimado é:

$$
P\left(K Z_{i t}=1 \mid X_{i t}, \beta, \alpha_{i}\right)=F\left[\alpha_{i}+\beta_{0}+\beta_{1}\left(\frac{F C}{K_{t-1}}\right)_{i t}+\beta_{2}\left(\frac{D}{K_{t-1}}\right)_{i t}+\beta_{3}\left(\frac{\text { Caixa }}{K_{t-1}}\right)_{i t}+\beta_{s c}^{\prime}(G C)_{i t}\right]
$$

em que $t$ é o ano, variando de 1 até T; $i$ é a firma, variando de 1 até $\mathrm{N} ; X_{i t}$ é a matriz contendo todas as variáveis explicativas; $\beta$ é um vetor de parâmetros desconhecidos; $\alpha_{i}$ é o efeito específico da firma; $F C_{i t}$ é o fluxo de caixa; $K_{t-l}$ é o estoque de capital; $D_{i t}$ é a dívida total; Caixa $_{\text {it }}$ é o disponível e os investimentos de curto prazo; e $G C_{i t}$ representa o conjunto de variáveis de governança corporativa utilizadas. Entre as variáveis de governança corporativa estão as seguintes variáveis binárias: estrutura de propriedade piramidal, a natureza da estrutura de propriedade e controle, a presença do maior acionista último no conselho de administração e a sua atuação como diretor executivo da firma e se a firma pertence a um dos níveis de governança corporativa instituídos pela BM\&FBOVESPA.

Embora a equação em (10) mostre a influência de algumas variáveis na probabilidade de restrição financeira, considera-se interessante também, investigar como mecanismos de governança corporativa e a presença da restrição financeira interferem na decisão de investimento da firma. $\mathrm{O}$ modelo proposto neste trabalho é uma versão modificada do modelo acelerador do investimento, e é dado por:

$$
\begin{aligned}
\left(\frac{I}{K_{t-1}}\right)_{i t} & =\alpha_{i}+\gamma_{1}\left(\frac{I}{K_{t-1}}\right)_{i, t-1}+\gamma_{2}\left(\frac{I}{K_{t-1}}\right)_{i, t-1}^{2}+\beta_{1}\left(\frac{F C}{K_{t-1}}\right)_{i t}+\beta_{2}\left(\frac{V}{K_{t-1}}\right)_{\mathrm{it}} \\
& +\beta_{3}\left(\frac{D}{K_{t-1}}\right)_{i t}+\beta_{4}\left(\frac{F C}{K_{t-1}}\right)_{i t} \times \operatorname{nivelgc}+\beta_{5}\left(\frac{F C}{K_{t-1}}\right)_{i t} \times \operatorname{dirfc} \\
& +\beta_{6}\left(\frac{F C}{K_{t-1}}\right)_{i t} \times \operatorname{dirvoto}+\beta_{g c}^{\prime}(G C)_{i t}+\varepsilon_{i t}
\end{aligned}
$$


em que $t$ é o ano, variando de 1 até T; $i$ é a firma, variando de 1 até $\mathrm{N} ; K_{i t}$ é o estoque de capital; $I_{i t}$ é o investimento da firma; $\alpha_{i}$ é o efeito específico da firma; $F C_{i t}$ é o fluxo de caixa; $V_{i t}$ é o volume de vendas; $D_{i t}$ é a dívida total; nivelgc é uma variável binária que assume valor 1 se a firma aderir a um dos níveis diferenciados de governança corporativa da BM\&FBOVESPA; dirfc é o percentual de direito de fluxo de caixa do maior acionista último e dirvoto é o percentual de direito de voto do maior acionista último; $G C_{i t}$ representa o conjunto das variáveis de governança corporativa utilizadas e, $\varepsilon_{i t}$ é o erro.

A divisão das variáveis financeiras pelo estoque de capital proporciona que o investimento seja medido em taxa e que as demais variáveis financeiras sejam analisadas como variações em relação ao estoque de capital. Para a escolha das variáveis introduzidas no modelo, considerou-se a ampla literatura sobre a teoria do investimento. A introdução das variáveis defasadas da variável dependente tem por objetivo considerar o aspecto dinâmico do comportamento do investimento. A variável defasada quadrática foi considerada para refletir a presença de um comportamento não-linear no processo de ajustamento pelo estoque de capital.

A variável fluxo de caixa $\left(F C / K_{t-1}\right)$ procura considerar o efeito de possíveis restrições de liquidez no comportamento do investimento, mas também pode refletir o potencial de rentabilidade futura da firma. A variável vendas $\left(V / K_{t-1}\right)_{i t}$ procura considerar o relacionamento do nível de vendas com a taxa de investimento das firmas. A introdução da variável dívida total $\left(D / K_{t-1}\right)_{i t}$ tem por objetivo considerar os benefícios tributários da dívida e o indício de que uma maior alavancagem pode aumentar o valor da firma.

Já a variável de interação entre o nível de governança corporativa e o fluxo de caixa $\left(\frac{F C}{K_{t-1}}\right) \times$ nivelgc procura analisar se firmas inseridas em um dos níveis diferenciados de governança corporativa possuem menor sensibilidade do investimento ao fluxo de caixa do que firmas que não aderiram a nenhum nível de governança corporativa. Assim, espera-se que $\beta_{4}<0$ já que firmas presente a um dos níveis diferenciados de governança corporativa, geralmente são bem vistas pelo mercado e consequentemente, podem possuir um melhor acesso a captação de recursos externos. A variável de interação entre o direito de fluxo de caixa e o fluxo de caixa $\left(\frac{F C}{K_{t-1}}\right) \times \operatorname{dirfc}$ tem por objetivo analisar se um aumento nos direitos de fluxo de caixa do maior acionista pode contribuir para reduzir a sensibilidade do investimento 
ao fluxo de caixa, visto que uma maior participação acionária destes acionistas poderia contribuir para a maximização de valor da firma. Portanto, espera-se que $\beta_{5}<0$.

Por fim, a variável de interação entre o direito de voto e o fluxo de caixa $\left(\frac{F C}{K_{t-1}}\right) \times$ dirvoto tem por objetivo verificar se firmas cujos maiores acionistas últimos detêm grande percentual de ações com direito a voto possuem alta sensibilidade do investimento ao fluxo de caixa. Como a alta concentração de votos pode ocasionar expropriação de riquezas dos acionistas minoritários e, consequentemente, a redução na captação de recursos, espera-se que uma elevação no nível de concentração de votos dos maiores acionistas últimos contribua para aumentar a sensibilidade do investimento ao fluxo de caixa, o que implicaria em $\beta_{6}>0$.

Assim, definidas as variáveis inseridas no modelo em (11) para analisar o comportamento das decisões de investimento das firmas na presença da restrição financeira e dos mecanismos de governança corporativa, convém agora discutir sobre a natureza dos dados sob a forma de painel e, consequentemente, apresentar os métodos disponíveis para a estimação deste modelo.

Dados em painel, também denominados por dados longitudinais, referem-se a dados de diferentes indivíduos $i$ observados em $T$ períodos de tempos distintos. Quando as informações estão completas para todos os indivíduos em todos os períodos, o painel é dito balanceado. Já quando existem informações incompletas sobre os indivíduos em algum período, o painel é denominado não balanceado.

Como o conjunto de dados na forma de painel requer a observação de vários indivíduos durante um período de tempo, alguns benefícios são obtidos com a utilização dos dados neste formato. Estes benefícios estão relacionados ao controle de certas características não observadas dos indivíduos, além da possibilidade de se investigar como momentos passados, medidos pelas defasagens de variáveis regressoras, podem influenciar na variável dependente. Dessa forma, as características não observadas dos indivíduos, também denominados por efeitos específicos, podem ser representadas por um componente $\alpha_{i}$ inserido no modelo a ser estimado e podem captar características específicas dos indivíduos que não se modificam ao longo dos anos. Deste modo, pode-se considerar os efeitos específicos $\alpha_{i}$ como uma variável aleatória ou como um componente fixo no modelo e, portanto a maneira com que $\alpha_{i}$ será interpretado irá diferir no método de estimação do modelo.

Nesse sentido, se os efeitos específicos forem considerados como um efeito aleatório, $\alpha_{i}$ será tratado como uma variável aleatória, pois se assume que o comportamento específico 
da firma é desconhecido, não podendo ser observado nem medido ao longo dos anos. Com isso, esses efeitos poderão ser representados sob a forma de uma variável aleatória com distribuição normal, o que permitirá que $\alpha_{i}$ seja incorporado ao erro do modelo em (11). O erro do modelo poderá então ser visto como: $v_{i t}=\alpha_{i}+\varepsilon_{i t}$ e não permitirá que $\alpha_{i}$ esteja correlacionado com os regressores $\mathrm{x}_{\mathrm{it}}$. Assim, como $\alpha_{i}$ está distribuído independentemente de $\mathrm{X}_{\mathrm{it}}$, as inferências dadas por esta estimação poderão ser estendidas a toda a população, e não somente a amostra analisada. Contudo, o estimador será inconsistente se $\alpha_{i}$ estiver correlacionado com as covariadas do modelo.

Já se os efeitos específicos da firma forem considerados fixos, $\alpha_{i}$ será caracterizada como uma constante (uma característica específica) não observada relativa a cada firma e que é invariante ao tempo. Isso permitirá que $\alpha_{i}$ esteja correlacionada com as variáveis regressoras, captando características específicas da firma, tal como a habilidade dos gestores que, no caso particular do modelo deste estudo, pode estar relacionada com as políticas de investimento, com o fluxo de caixa, aquisição de dívidas, entre outras características, que envolvem a política adotada pelos gestores da firma, mas que não podem ser mensuradas. Por este motivo, estudos que envolvem a decisão de investimento optam por considerar $\alpha_{i}$ como um efeito fixo.

Outro importante fator relacionado ao modelo em (11) é que ele considera o uso da variável dependente defasada em $t-1$ como uma variável regressora. Isso oferece um caráter dinâmico ao modelo, mas em contrapartida, permite a existência de correlação entre $y_{i, t-1} \mathrm{e}$ $\varepsilon_{i t}{ }^{39}$, exigindo que a estimação seja realizada por um método específico que corrija este problema. Desta forma, Anderson e Hsiao (1981) sugeriram um método baseado no método de primeiras diferenças e no uso de variáveis instrumentais ${ }^{40}$.

A título de exemplificação, considere um modelo genérico para o modelo em (11) tal como:

$$
y_{i t}=\alpha_{i}+\gamma y_{i, t-1}+X_{i t}^{\prime} \beta+\varepsilon_{i t}
$$

assim,

$$
y_{i, t-1}=\alpha_{i}+\gamma y_{i, t-2}+X_{i, t-1}^{\prime} \beta+\varepsilon_{i, t-1}
$$

\footnotetext{
39 Variáveis regressoras que possuem correlação com o erro são comumente denominadas na literatura por variáveis endógenas.

40 Variável instrumental é uma variável correlacionada com a variável explicativa endógena $y_{i, t-1}$ que não aparece no modelo e que é não correlacionada com o erro (Wooldridge, 2006).
} 
em que $t$ é o ano, variando de 1 até T; $i$ é a firma, variando de 1 até $\mathrm{N}$; $y_{i t}$ é a variável dependente; $\alpha_{i}$ é o efeito específico da firma considerado fixo; $X_{i t}$ é uma matriz que representa as variáveis explicativas; $\beta$ e $\gamma$ são vetores de parâmetros desconhecidos e, $\varepsilon_{i t}$ é o termo de erro.

Com o método de primeiras diferenças, o efeito específico da firma é eliminado, pois se realiza a diferença entre as equações em (12) e em (13):

$$
y_{i t}-y_{i, t-1}=\gamma\left(y_{i, t-1}-y_{i, t-2}\right)+\left(\mathrm{x}_{\mathrm{it}}-\mathrm{x}_{\mathrm{i}, \mathrm{t}-1}\right)^{\prime} \beta+\left(\varepsilon_{i t}-\varepsilon_{i, t-1}\right), \quad \operatorname{com} t=3, \ldots, T
$$

A proposta de Anderson e Hsiao (1981) foi considerar $y_{i, t-2}$ como um instrumento para $\left(y_{i, t-1}-y_{i, t-2}\right)^{41}$ e estimar a equação em (14) pelo método de variáveis instrumentais. No entanto, o instrumento utilizado só será válido caso $y_{i, t-2}$ não esteja correlacionado com $\Delta \varepsilon_{i t}=\left(\varepsilon_{i t}-\varepsilon_{i, t-1}\right)$, mas que esteja correlacionado com $\left(y_{i, t-1}-y_{i, t-2}\right)$. Uma vantagem do método sugerido por estes autores é a possibilidade de se introduzir mais variáveis defasadas no modelo. A desvantagem é que o estimador deste método considera os erros homoscedásticos, o que não é garantido pelo método proposto Anderson e Hsiao (1981). Além disso, devido ao fato de não utilizar todas as condições dos momentos disponíveis ${ }^{42}$ e não considerar a estrutura diferenciada dos resíduos $\Delta \varepsilon_{i t}$, a estimação pelo uso de variáveis instrumentais conduz a estimadores consistentes, mas não necessariamente eficientes.

A fim de tornar a estimação mais eficiente, Arellano e Bond (1991) sugeriram utilizar como instrumento todas as variáveis dependentes defasadas disponíveis a cada momento, ou seja:

\footnotetext{
${ }^{41}$ Considerar o uso de $y_{i, t-2}$ como variável instrumental requer a disponibilidade de pelo menos três períodos para cada individuo $i$.

${ }^{42}$ De acordo com Stock e Watson (2004), as condições de momentos estão relacionados aos valores esperados de uma variável aleatória. Por exemplo, a média da variável aleatória $Y, E(Y)$, é denominado o primeiro momento de $\mathrm{Y}$ e, o valor esperado de $Y^{2}$ é chamado de segundo momento de $Y$. Generalizando, o valor esperado de $Y^{r}$ será chamado de r-ésimo momento de $Y$, que será $E\left(Y^{r}\right)$. A partir desta consideração, uma classe de estimadores surgiu, dando origem a métodos de estimação baseados nas condições de momentos. Um desses métodos é denominado por método dos momentos (MM) e, sua generalização, método dos momentos generalizados (GMM). Cameron e Trivedi (2005) citam como exemplo de estimador MM as condições de momento da amostra que correspondem as condições de momento da população. Assim, pode-se dizer que a média da amostra é o estimador MM da média da população. Entretanto, para a aplicação do MM necessita-se que o número de parâmetros seja igual ao número de condições de momentos, o que faz com que em algumas situações, o estimador MM seja inviável, pois haverá mais condições de momentos do que parâmetros. Logo, será mais eficaz considerar a estimação pelo GMM, que considera todas as condições de momentos disponíveis.
} 


$$
E\left(y_{i, t-s}, \Delta \varepsilon_{i t}\right)=0 \quad \text { para } s=2, \ldots,(t-1) \text { e } t=3, \ldots, T
$$

Desse modo, por construção, o método proposto por Arellano e Bond (1991) permite o uso de variáveis explicativas que estejam correlacionadas com períodos anteriores, isto é:

$$
E\left(x_{i, t}, \varepsilon_{i s}\right) \neq 0 \quad \text { para } s<t
$$

Estas variáveis explicativas correlacionadas com períodos anteriores são denominadas por fracamente exógenas ou pré-determinadas. Assim, considerando o uso de instrumentos válidos tanto para a variável dependente defasada quanto para as possíveis defasagens das variáveis explicativas, o modelo em (12) torna-se superidentificado ${ }^{43}$, satisfazendo todas as condições de momentos. Com isso, a validade da estimação pelo método proposto por Arellano e Bond (1991) dependerá da validade dos instrumentos e da inexistência de correlação dos instrumentos com o resíduo. Nesse sentido, os autores propuseram explorar as condições de ortogonalidade existentes entre as defasagens da variável dependente $y_{i t}$ e o termo de erro $\varepsilon_{i t}$, ou seja:

$$
E\left(y_{i t} \varepsilon_{i s}\right) \neq 0 \text { para } s<t \text { e } E\left(y_{i t} \varepsilon_{i s}\right)=0 \text { para } s \geq t
$$

garantindo a inexistência de correlação entre $y_{i t}$ e o termo de erro $\varepsilon_{i t}$ para momentos futuros.

Além disso, para garantir a homoscedasticidade nos resíduos, Arellano e Bond (1991) sugeriram que a estimação fosse realizada por meio do Método dos Momentos Generalizados em dois estágios (GMM-twostep $)^{44}$. Este método garante a eficiência dos estimadores, dado que no primeiro passo será garantido a homescedasticidade e a independência de $\varepsilon_{i t}$, e no segundo será obtida a matriz de ponderação ótima a partir dos resíduos produzidos no primeiro passo, o que fornecerá o estimador mais eficiente quando se admitir a não correlação das variáveis instrumentais $\operatorname{com} \varepsilon_{i t}$.

Como a eficiência do estimador depende da exogeneidade das variáveis instrumentais em relação ao erro e da inexistência de correlação serial no resíduo, testes que garantam a existência de não correlação são fundamentais para se verificar a validade dos instrumentos

\footnotetext{
${ }^{43} \mathrm{O}$ modelo é dito superidentificado quando o número de instrumentos é superior ao número de variáveis regressoras.

${ }^{44}$ Arellano e Bond (1991) também consideraram a estimação pelo GMM-one step. Entretanto, esse método de estimação não garante a existência de homoscedasticidade e não correlação dos resíduos.
} 
utilizados. Considerando que $\varepsilon_{i t}$ não admite correlação serial, então $\Delta \varepsilon_{i t}$ é correlacionado $\operatorname{com} \Delta \varepsilon_{i, t-1}$ pois:

$$
\operatorname{Cov}\left(\Delta \varepsilon_{i t}, \Delta \varepsilon_{i, t-1}\right)=\operatorname{Cov}\left(\varepsilon_{i t}-\varepsilon_{i, t-1}, \varepsilon_{i, t-1}-\varepsilon_{i, t-2}\right)=-\operatorname{Cov}\left(\varepsilon_{i, t-1}, \varepsilon_{i, t-1}\right) \neq 0
$$

e assim, $\Delta \varepsilon_{i t}$ não será correlacionado com $\Delta \varepsilon_{i, t-k}$ se $k \geq 2$. Dessa forma, Arellano e Bond (1991) sugeriram um teste de autocorrelação serial, que seguirá uma distribuição normal padronizada e irá analisar, sob a hipótese nula, a existência de correlação com o resíduo. Já o teste de Sargan para modelos superidentificados investiga a legitimidade das variáveis instrumentais utilizadas. Este teste analisa se existe diferença significativa em relação ao número de instrumentos adicionais, ou seja, se a diferença entre o número de instrumentos e o número de variáveis regressoras é significativa ${ }^{45}$. A rejeição da hipótese nula de validade dos instrumentos é interpretada como uma evidencia de que pelo menos um dos instrumentos utilizados no modelo é endógeno, portanto, o teste requer que a hipótese nula seja não rejeitada.

Assim, para investigar como os mecanismos de governança corporativa e a restrição financeira afetam a taxa de investimento das firmas, o modelo em (11) foi estimado pelo método GMM proposto por Arellano e Bond (1991) ${ }^{46}$. Além disso, assumindo que a decisão da firma investir no período $t$ é tomada baseada em decisões gerenciais realizadas em momentos passados - decisões estas que envolvem o comportamento dos gestores, requerimento de empréstimos, volume de vendas, fluxo de caixa, dentre outras; as variáveis: fluxo de caixa, dívida total e vendas foram consideradas pré-determinadas.

Como no modelo em (11) está inserida uma defasagem da variável dependente, o teste de autocorrelação e o teste de Sargan foram aplicados. O teste de autocorrelação indicou a inexistência de autocorrelação de segunda ordem entre o erro e $y_{i t}$. Já o teste de Sargan para modelos superidentificados confirmou a validade dos instrumentos utilizados. Contudo, como a amostra consiste de firmas com diferentes características, é preciso considerar a presença de heterogeneidade entre as firmas. Para reduzir este problema, estudos que analisam as decisões de investimento sugerem que as firmas sejam organizadas em grupos de acordo com características em comum, o que tornaria cada grupo um pouco mais homogêneo. Nesse

\footnotetext{
${ }^{45} \mathrm{O}$ teste seguirá uma distribuição $\chi^{2}(r-k)$ em que $\mathrm{r}$ é o número de instrumento e $\mathrm{k}$ é o número de variáveis regressoras.

${ }^{46}$ Um fato interessante do método desenvolvido por Arellano e Bond (1991) é que sua estimação se aplica igualmente tanto para painéis balanceados quanto para painéis não balanceados.
} 
sentido, o modelo em (11) foi estimado considerando-se três formas distintas de agrupamento. Em um primeiro momento, as firmas foram agrupadas de acordo com o índice $\mathrm{KZ}$ entre firmas consideradas restritas e não restritas financeiramente. Em seguida, as firmas foram agrupadas de acordo com o pagamento de dividendos, e por tamanho.

As estimações obtidas tanto pelo GMM quanto pelo modelo probabilístico logit em efeito aleatório serão apresentadas no próximo capítulo, juntamente com a análise e a interpretação econômica dos resultados. Neste capítulo, também será realizada uma análise descritiva dos indicadores financeiros e das características de governança corporativa das firmas. 


\section{Decisões de Investimento e Restrição Financeira: a influência de aspectos de Governança Corporativa.}

Nos capítulos anteriores apresentou-se uma breve revisão de literatura dos principais trabalhos sobre governança corporativa e restrição financeira, ressaltando os importantes fundamentos da governança corporativa e seus benefícios relacionados à valorização das ações das firmas e dos interesses dos investidores. Embora muito se questione sobre como as práticas de governança corporativa influenciam no comportamento do investidor e do mercado, pouco se sabe sobre como a governança corporativa interfere nas decisões de investimento das firmas na presença de restrição financeira.

Desta forma, o presente capítulo tem por objetivo investigar como a governança corporativa e a presença da restrição financeira influenciam no comportamento das decisões de investimento das firmas. Com um painel não balanceado de 500 firmas brasileiras de capital aberto no período de 1997 a 2007 estimou-se um modelo probabilístico logit por efeito aleatório e um modelo de investimento estimado pelo Método dos Momentos Generalizados (GMM). Para reduzir a heteroscedasticidade presente entre as firmas, a estimação do modelo de investimento foi realizada considerando-se três agrupamentos: índice KZ, pagamento de dividendos e tamanho das firmas. Os resultados dos modelos em (10) e em (11) serão apresentados após a análise descritiva da amostra.

A tabela 1 reporta as estatísticas descritivas da amostra total e da amostra dividida de acordo com o índice $\mathrm{KZ}$ entre firmas consideradas restritas e não restritas financeiramente. Como era de se esperar, pela própria construção do índice KZ, firmas classificadas como restritas financeiramente apresentaram baixos valores médios para a taxa de investimento, fluxo de caixa, disponível e fluxo de caixa livre quando comparadas com as firmas consideradas não restritas financeiramente. Isso foi observado principalmente em relação à variável fluxo de caixa $\left(F C / K_{t-1}\right)$ que, para firmas consideradas restritas foi, aproximadamente, cinco vezes inferior ao fluxo de caixa do outro grupo de firmas. Já a taxa de investimento de firmas consideradas não restritas mostrou-se 5,4 vezes maior do que a taxa de investimento do grupo de firmas consideradas restritas financeiramente. Tanto o disponível, medido pela variável Caixa, quanto o fluxo de caixa livre $(F C L)$ apresentaram maiores médias para as firmas consideradas não restritas, quando comparados com as médias das firmas classificadas como restritas financeiramente. Esses fracos indicadores das variáveis de liquidez para o 
grupo de firmas consideradas restritas podem estar associados à maior necessidade de caixa e a alta dependência de recursos externos.

De acordo com a tabela 1, entre as firmas classificadas como não restritas financeiramente estão as firmas de maior porte. Isso pode estar associado com um melhor acesso ao financiamento de um baixo custo que firmas maiores tenderiam a ter no mercado de capitais. Em relação à receita operacional líquida, medida pela variável $\left(V / K_{t-1}\right)$, firmas consideradas não restritas financeiramente apresentaram, em média, maior nível de vendas do que as firmas classificadas como restritas. O baixo volume de vendas das firmas restritas pode estar indicando uma maior necessidade de recursos externos para a realização de investimentos.

Tabela 1: Características Financeiras das firmas - Estatísticas Descritivas: Índice KZ

\begin{tabular}{|c|c|c|c|c|c|c|}
\hline \multirow{3}{*}{ Indicadores } & \multirow{2}{*}{\multicolumn{2}{|c|}{ Amostra Total }} & \multicolumn{4}{|c|}{ Amostra dividida em grupos } \\
\hline & & & \multicolumn{2}{|c|}{ Firmas não Restritas } & \multicolumn{2}{|c|}{ Firmas Restritas } \\
\hline & Média & $\begin{array}{l}\text { Desvio } \\
\text { Padrão }\end{array}$ & Média & $\begin{array}{l}\text { Desvio } \\
\text { Padrão }\end{array}$ & Média & $\begin{array}{l}\text { Desvio } \\
\text { Padrão }\end{array}$ \\
\hline $\mathrm{I} / \mathrm{K}_{\mathrm{t}-1}$ & 0,0361 & 0,3987 & 0,0572 & 0,3917 & 0,0106 & 0,3514 \\
\hline $\mathrm{FC} / \mathrm{K}_{\mathrm{t}-1}$ & 0,2387 & 0,4611 & 0,4413 & 0,5145 & 0,0898 & 0,3041 \\
\hline Caixa/K $\mathrm{K}_{\mathrm{t}-1}$ & 0,3745 & 0,8622 & 0,6465 & 1,1424 & 0,1765 & 0,2724 \\
\hline FCL/V & 0,1504 & 1,4120 & 0,2083 & 0,6154 & 0,0919 & 1,9020 \\
\hline $\mathrm{V} / \mathrm{K}_{\mathrm{t}-1}$ & 3,0559 & 4,7346 & 4,0624 & 5,0324 & 2,1508 & 2,6778 \\
\hline AT & $4,22 \mathrm{E}+06$ & $1,49 \mathrm{E}+07$ & $6,09 \mathrm{E}+06$ & $1,87 \mathrm{E}+07$ & $5,34 \mathrm{E}+06$ & $1,75 \mathrm{E}+07$ \\
\hline $\mathrm{ELP} / \mathrm{K}_{\mathrm{t}-1}$ & 0,8255 & 1,0706 & 0,7239 & 0,9041 & 0,8601 & 0,9530 \\
\hline $\mathrm{PC} / \mathrm{K}_{\mathrm{t}-1}$ & 1,1661 & 1,6487 & 1,3438 & 1,8911 & 1,0530 & 1,4645 \\
\hline $\mathrm{D} / \mathrm{K}_{\mathrm{t}-1}$ & 1,9916 & 2,2409 & 2,0677 & 2,3992 & 1,9131 & 2,0721 \\
\hline $\mathrm{D} / \mathrm{AT}$ & 0,5352 & 0,2157 & 0,4722 & 0,1797 & 0,6266 & 0,1816 \\
\hline $\mathrm{D} / \mathrm{PL}$ & 2,4404 & 3,4771 & 1,3734 & 1,6401 & 3,4117 & 4,0519 \\
\hline ROA & 0,0182 & 0,1161 & 0,0667 & 0,0779 & $-0,0029$ & 0,0832 \\
\hline LL/PL & $-0,0206$ & 0,4831 & 0,1288 & 0,2667 & $-0,0802$ & 0,4931 \\
\hline $\mathrm{LO} / \mathrm{K}_{\mathrm{t}-1}$ & 0,1266 & 0,5953 & 0,3445 & 0,5094 & $-0,0088$ & 0,3828 \\
\hline
\end{tabular}

Notas: Esta tabela reporta as médias das variáveis financeiras da amostra total e da amostra divida em grupos de firmas consideradas restritas e não restritas financeiramente. O subscrito $t$ indexa o período. A descrição das variáveis encontra-se no apêndice A.

Quando se analisa o nível de endividamento em relação ao ativo total (D/AT) ou ao patrimônio líquido $(D / P L)$, nota-se um maior nível de endividamento para as firmas consideradas restritas financeiramente. Esse maior endividamento ocorre principalmente em relação à variável $D / P L$ que considera a razão entre dívida e patrimônio líquido das firmas consideradas restritas pelo índice KZ. Observa-se que essas firmas possuem, em média, um 
endividamento mais do que três vezes maior que seu patrimônio líquido, o que pode estar evidenciando uma maior possibilidade de falência para este grupo de firmas.

Firmas consideradas não restritas financeiramente apresentaram índices de rentabilidade, medido pelas variáveis $R O A$ e $L L / P L$, elevados quando comparados ao grupo de firmas consideradas restritas. Já as firmas consideradas financeiramente restritas apresentaram médias negativas tanto para a razão entre o lucro líquido e o ativo total quanto para a razão entre o lucro líquido e o patrimônio líquido. O mesmo comportamento pode ser observado para a variável $L O / K_{t-1}$, que relaciona lucro operacional e o estoque de capital.

A tabela 2 apresenta as características sobre a estrutura de propriedade e controle. Firmas com estrutura de propriedade piramidal estão distribuídas em 60,9\% das firmas presentes na amostra. Quando a amostra é dividida em grupos pelo índice KZ, este percentual difere entre firmas consideradas restritas e não restritas financeiramente, o que permite observar uma maior concentração de firmas com estrutura de propriedade piramidal entre as firmas consideradas restritas.

Tabela 2: Estrutura de Propriedade e Controle - Estatísticas Descritivas

\begin{tabular}{|c|c|c|c|c|c|c|c|}
\hline & \multirow{3}{*}{ Variáveis } & \multirow{2}{*}{\multicolumn{2}{|c|}{ AmostraTotal }} & \multicolumn{4}{|c|}{ Amostra dividida em grupos } \\
\hline & & & & \multicolumn{2}{|c|}{ Firmas não Restritas } & \multicolumn{2}{|c|}{ Firmas Restritas } \\
\hline & & Média & \multirow{2}{*}{$\begin{array}{l}\begin{array}{l}\text { Desvio } \\
\text { Padrão }\end{array} \\
0,4879\end{array}$} & \multirow{2}{*}{$\begin{array}{l}\text { Média } \\
0,6099 \\
\end{array}$} & \multirow{2}{*}{$\begin{array}{l}\begin{array}{l}\text { Desvio } \\
\text { Padrão }\end{array} \\
0,4881\end{array}$} & \multirow{2}{*}{$\begin{array}{l}\text { Média } \\
0,6686 \\
\end{array}$} & \multirow{2}{*}{$\begin{array}{l}\text { Desvic } \\
\text { Padrã } \\
0,4710\end{array}$} \\
\hline & Pirâmide & 0,6099 & & & & & \\
\hline \multicolumn{2}{|c|}{ Maior Acionista Último } & - & - & - & - & - & - \\
\hline \multirow{6}{*}{$\begin{array}{l}\text { Natureza } \\
\text { do Maior } \\
\text { Acionista } \\
\text { Último (LUS) }\end{array}$} & Acordo entre acionistas & 0,0623 & 0,2417 & 0,0729 & 0,2601 & 0,0719 & 0,2585 \\
\hline & Estatal & 0,0630 & 0,2429 & 0,0764 & 0,2658 & 0,0731 & 0,2605 \\
\hline & Estrangeira & 0,1915 & 0,3935 & 0,1927 & 0,3947 & 0,2276 & 0,4195 \\
\hline & Familiar & 0,5508 & 0,4975 & 0,5323 & 0,4992 & 0,5047 & 0,5003 \\
\hline & Institucional & 0,0422 & 0,2011 & 0,0294 & 0,1690 & 0,0531 & 0,2243 \\
\hline & Outros & 0,0902 & 0,1844 & 0,0963 & 0,1874 & 0,0695 & 0,1787 \\
\hline \multicolumn{2}{|r|}{ Controle } & 0,7591 & 0,4277 & 0,7538 & 0,4310 & 0,7892 & 0,4081 \\
\hline \multirow{6}{*}{$\begin{array}{l}\text { Natureza do } \\
\text { Acionista } \\
\text { Controlador }\end{array}$} & Acordo entre acionistas & 0,0530 & 0,2242 & 0,0622 & 0,2418 & 0,0542 & 0,2266 \\
\hline & Estatal & 0,0566 & 0,2312 & 0,0658 & 0,2480 & 0,0707 & 0,2565 \\
\hline & Estrangeira & 0,1456 & 0,3528 & 0,1480 & 0,3553 & 0,1792 & 0,3837 \\
\hline & Familiar & 0,4100 & 0,4919 & 0,3783 & 0,4852 & 0,4139 & 0,4928 \\
\hline & Institucional & 0,0253 & 0,1572 & 0,0141 & 0,1179 & 0,0294 & 0,1694 \\
\hline & Outros & 0,0681 & 0,1592 & 0,0857 & 0,1815 & 0,0412 & 0,1402 \\
\hline
\end{tabular}

Como dito anteriormente, o maior acionista último é aquele que detém maior percentual de direito de voto. Dessa forma, este acionista pode ser classificado de acordo com sua natureza, ou seja, em familiar, estatal, estrangeira, institucional (fundos de pensão e 
investimento), delimitado por acordo entre acionistas, e outros (S.As, fundações, instituições). Isso permite observar uma maior incidência de firmas com natureza de propriedade familiar $(55 \%)$ e natureza estrangeira $(19,1 \%)$ na amostra. Já se o maior acionista último possuir mais do que $50 \%$ do total de direito de voto da firma, este é caracterizado como o acionista controlador. A característica do maior acionista último como acionista controlador é identificada pela variável controle, que mostrou que 75,9\% das firmas presentes na amostra são controladas pelo maior acionista último. Além disso, esta variável apresentou-se um pouco maior para as firmas consideradas restritas financeiramente, mostrando que há uma maior incidência de acionistas controladores entre as firmas pertencentes a este grupo de firmas.

Na tabela 2 também foi apresentada as estatísticas descritivas das naturezas do maior acionista último e do acionista controlador (que também é o maior acionista último). Nesse sentido, pôde-se analisar se a distribuição das naturezas do maior acionista último entre firmas consideradas restritas e não restritas financeiramente é afetada quando este acionista é o acionista controlador. Assim, pôde-se perceber que quando se considera apenas a natureza do maior acionista último, há uma maior frequência de firmas com natureza familiar entre as firmas consideradas não restritas financeiramente. No entanto, se este maior acionista último for o acionista controlador observa-se que o controle familiar está mais presente entre as firmas consideradas restritas financeiramente. Isso pode estar indicando que a presença do maior acionista último como controlador em firmas familiares implica em uma elevação no nível de restrição financeira da firma, provavelmente devido ao potencial de expropriação de recursos dos acionistas minoritários por parte destes acionistas controladores.

Já quando se considera o maior acionista último com natureza estrangeira, nota-se que $22,7 \%$ das firmas classificadas como restritas financeiramente possuem este tipo de natureza, sendo este percentual superior ao de firmas consideradas não restritas (19,2\%). Essa maior incidência de firmas com natureza estrangeira se manterá no grupo de firmas consideradas restritas financeiramente mesmo que este maior acionista último seja o acionista controlador das firmas.

Em relação as naturezas estatal e acordo entre acionistas, estas não apresentaram diferenças percentuais quando as firmas foram agrupadas entre firmas restritas e não restritas financeiramente de acordo com o índice KZ, mostrando que tais naturezas podem não influenciar no grau de restrição das firmas. O mesmo pôde ser observado quando o maior acionista último é o acionista controlador dado a baixa diferença percentual entre as firmas consideradas restritas e não restritas financeiramente. 
A tabela 3 apresenta as estatísticas descritivas das variáveis relacionadas com a participação do maior acionista último na firma, isto é, a presença deste acionista no conselho de administração e na direção, seus percentuais de direito de voto e de fluxo de caixa e, consequentemente, o desvio entre esses direitos.

Tabela 3: Participação do Maior Acionista Último- Estatísticas Descritivas

\begin{tabular}{|c|c|c|c|c|c|c|}
\hline \multirow{3}{*}{ Variável } & \multirow{2}{*}{\multicolumn{2}{|c|}{ AmostraTotal }} & \multicolumn{4}{|c|}{ Amostra dividida em grupos } \\
\hline & & & \multicolumn{2}{|c|}{ Firmas não Restritas } & \multicolumn{2}{|c|}{ Firmas Restritas } \\
\hline & Média & $\begin{array}{l}\text { Desvio } \\
\text { Padrão }\end{array}$ & Média & $\begin{array}{l}\text { Desvio } \\
\text { Padrão }\end{array}$ & Média & $\begin{array}{l}\text { Desvio } \\
\text { Padrão }\end{array}$ \\
\hline Direito de FC & 0,4571 & 0,2765 & 0,4136 & 0,2626 & 0,4348 & 0,2635 \\
\hline Direito de Voto & 0,6734 & 0,2698 & 0,6418 & 0,2700 & 0,6987 & 0,2575 \\
\hline Desvio & 0,2225 & 0,2211 & 0,2317 & 0,2111 & 0,2690 & 0,2300 \\
\hline Conselho & 0,5347 & 0,4989 & 0,5288 & 0,4995 & 0,5006 & 0,5003 \\
\hline Diretor & 0,3815 & 0,4858 & 0,3588 & 0,4799 & 0,3211 & 0,4672 \\
\hline CD & 0,3631 & 0,4810 & 0,3486 & 0,4768 & 0,3065 & 0,4613 \\
\hline
\end{tabular}

Nota: A variável binária $C D$ representa os maiores acionistas últimos que atuam simultaneamente no conselho de administração e na direção das firmas.

Para a amostra total, a análise evidencia que, em média, os direitos de voto do maior acionista último $(67,3 \%)$ é maior do que seus direitos de fluxo de caixa $(45,7 \%)$, logo, o desvio entre os direitos de voto e de fluxo de caixa é positivo em $22,2 \%$. Embora haja pouca diferença percentual entre as variáveis direitos de voto e direito de fluxo de caixa quando se analisa a amostra dividida em grupos, firmas consideradas restritas financeiramente apresentaram maiores valores para estas variáveis, o que reflete em um maior desvio entre os direitos para o grupo de firmas consideradas restritas. Isso pode estar indicando que firmas consideradas restritas financeiramente possuem um maior potencial para a expropriação das riquezas dos acionistas minoritários.

Em 38\% das firmas presentes na amostra, o maior acionista último atua como diretor e em 53\% das firmas, o maior acionista último é membro do conselho de administração. Para analisar uma possível sobreposição de funções por parte do maior acionista último, a variável $C D$ foi criada, na qual assume valor igual a 1 caso o maior acionista último que atuar como diretor também estiver presente no conselho de administração. A variável $C D$ mostra que, em média, 36\% das firmas possuem o maior acionista último como diretor e membro do conselho de administração. Isto indica que em 36\% das firmas presentes na amostra, quando o maior acionista último está presente na direção da firma, ele também está presente como membro do conselho de administração. Embora haja pouca diferença percentual entre os grupos, pôde-se observar que as variáveis $C D$, conselho e diretor apresentaram maiores valores para as firmas 
consideradas não restritas financeiramente, o que pode estar indicando que a participação do maior acionista último nas firmas pode contribuir para reduzir a presença de informações assimétricas entre gestores e acionistas, reduzindo os custos de agência.

A tabela 4 foi inserida para analisar se a participação do maior acionista último difere de acordo com a natureza do acionista controlador, considerando a amostra total:

Tabela 4: Participação do maior acionista último versus a natureza do acionista controlador

\begin{tabular}{lccccc}
\hline \multirow{2}{*}{ Variáveis } & \multicolumn{5}{c}{ Natureza do Acionista Controlador } \\
\cline { 2 - 6 } & $\begin{array}{c}\text { Acordo entre } \\
\text { Acionistas }\end{array}$ & Estatal & Estrangeiro & Familiar & Institucional \\
\hline Direito de FC & 0,5988 & 0,5533 & 0,6160 & 0,4673 & 0,6509 \\
Direito de Voto & 0,7876 & 0,7949 & 0,8202 & 0,7813 & 0,8840 \\
Desvio & 0,1761 & 0,2416 & 0,2042 & 0,3137 & 0,2332 \\
Conselho & 0,4907 & 0 & 0,0385 & 0,8811 & 0,0260 \\
Diretor & 0,2422 & 0 & 0,0158 & 0,6764 & 0,0130 \\
CD & 0,2298 & 0 & 0,0158 & 0,6466 & 0 \\
\hline Nota: A variável binária $C D$ representa os maiores & acionistas últimos que atuam & simultaneamente no conselho de \\
administração e na direção das firmas. & \multicolumn{5}{c}{} \\
\end{tabular}

De acordo com o esperado, a média dos direitos de voto em todas as naturezas do maior acionista último é maior do que $50 \%$ devido a própria construção da variável controle e das naturezas do acionista controlador. Observa-se que o maior acionista último de firmas com controle familiar são os que menos possuem direitos sobre o fluxo de caixa, o que proporciona o maior desvio de direitos em relação a todas as demais naturezas do acionista controlador, isto é, aparentemente este grupo de firmas possui o maior potencial de expropriação de recursos de seus acionistas minoritários por parte dos controladores. É também na natureza familiar de controle que o maior acionista último mais participa como membro do conselho de administração e da direção da firma, já que $88 \%$ deles participam do conselho, $67 \%$ da direção e $64 \%$ participam ativamente nos dois cargos. Para as firmas com controle estatal presentes na amostra, estas não possuem participação do maior acionista último tanto no conselho de administração quanto na direção da firma. Em seguida, as firmas com natureza de controle institucional e estrangeira são as que menos possuem participação de seus acionistas controladores: apenas 2,6\% (3\%) dos maiores acionistas últimos de firmas institucionais (estrangeira) estão presentes no conselho de administração e 1,3\% (1,5\%) na direção da firma.

A tabela 5 apresenta a distribuição das firmas entre os níveis de governança corporativa da BM\&FBOVESPA, considerando a amostra total e a amostra dividida em grupos de acordo com o índice KZ: 
Tabela 5: Níveis de Governança Corporativa - Estatística Descritiva

\begin{tabular}{|c|c|c|c|c|c|c|}
\hline \multirow{3}{*}{ Variáveis } & \multirow{2}{*}{\multicolumn{2}{|c|}{ AmostraTotal }} & \multicolumn{4}{|c|}{ Amostra dividida em grupos } \\
\hline & & & \multicolumn{2}{|c|}{ Firmas não Restritas } & \multicolumn{2}{|c|}{ Firmas Restritas } \\
\hline & Média & $\begin{array}{l}\text { Desvio } \\
\text { Padrão }\end{array}$ & Média & $\begin{array}{l}\text { Desvio } \\
\text { Padrão }\end{array}$ & Média & $\begin{array}{l}\text { Desvio } \\
\text { Padrão } \\
\end{array}$ \\
\hline Nível 1 & 0,0303 & 0,1714 & 0,0525 & 0,2232 & 0,0514 & 0,2209 \\
\hline Nível 2 & 0,0137 & 0,1162 & 0,0257 & 0,1582 & 0,0152 & 0,1224 \\
\hline Novo Mercado & 0,0479 & 0,2136 & 0,0618 & 0,2410 & 0,0432 & 0,2035 \\
\hline Nivelgc & 0,0919 & 0,2889 & 0,1400 & 0,3472 & 0,1098 & 0,3128 \\
\hline
\end{tabular}

Notas: A variável binária nivelgc assume valor igual a 1 se a firma estiver inserida em pelo menos um dos níveis de governança corporativa da BM\&FBOVESPA e no Novo Mercado.

A variável binária de governança corporativa nivelgc identifica as firmas que estão inseridas em pelo menos um dos segmentos de listagem da BM\&FBOVESPA, isto é, Nível 1, Nível 2 ou Novo Mercado. Dessa forma, nota-se pela tabela 5, que apenas 9,1\% das firmas contidas na amostra estão presentes em uma das classificações de governança corporativa da BM\&FBOVESPA. Desse percentual, 3\% das firmas estão inseridas no Nível 1, 1,3\% no Nível 2 e 4,7\% no Novo Mercado. Considerando os grupos de firmas classificadas como restritas ou não restritas financeiramente de acordo com o índice KZ, não foi possível identificar se firmas que aderiram ao Nível 1 são mais restritas financeiramente ou não, dada a inexistência de diferença percentual entre os grupos. Já quando se considera as firmas que aderiram ao Nível 2, nota-se que existe uma maior concentração destas firmas no grupo de firmas consideradas não restritas financeiramente. $\mathrm{O}$ mesmo foi observado para as firmas que se inseriram no Novo Mercado.

Exploradas as características financeiras e de governança corporativa das firmas, estimou-se o modelo probabilístico logit para dados em painel por efeito aleatório. A variável dependente deste modelo é a variável binária $K Z$ que assume valor igual a 1 se a firma for classificada como restrita financeiramente e zero, caso a firma seja considerada não restrita financeiramente. O sinal positivo (negativo) das variáveis explicativas indica um aumento (diminuição) na probabilidade da firma ser considerada restrita financeiramente. Três modelos foram estimados, diferindo apenas pelas variáveis: conselho, diretor e $C D$.

A tabela 6 apresenta os parâmetros estimados do modelo logit. O sinal negativo e significativo do coeficiente da variável fluxo de caixa $\left(F C / K_{t-1}\right)$ indica que uma maior disponibilidade de fundos internos reduz a probabilidade de a firma ser considerada restrita financeiramente. A disponibilidade de caixa e de investimentos de curto prazo, medido pela variável Caixa, também contribuem para reduzir a restrição financeira das firmas. O sinal positivo e significativo do coeficiente da variável dívida total $\left(D / K_{t-1}\right)$ mostra que o aumento 
no grau de alavancagem da firma eleva sua probabilidade de restrição financeira. Isso pode estar relacionado ao fato de que o mercado associa alta alavancagem ao maior risco de insolvência e de falência a que estas firmas estão sujeitas, restringindo a concessão de empréstimos de longo prazo.

Tabela 6: Estimação dos Parâmetros - Logit Efeito Aleatório

\begin{tabular}{|c|c|c|c|}
\hline \multirow{2}{*}{ Variáveis } & \multicolumn{3}{|c|}{ LOGIT por Efeito Aleatório } \\
\hline & (1) & (2) & (3) \\
\hline $\mathrm{FC} / \mathrm{K}_{\mathrm{t}-1}$ & $\begin{array}{l}-3,4030^{* * * *} \\
(0,4204)\end{array}$ & $\begin{array}{l}-3,2799^{* * *} \\
(0,4087)\end{array}$ & $\begin{array}{l}-3,4086^{* * * *} \\
(0,4208)\end{array}$ \\
\hline $\mathrm{D} / \mathrm{K}_{\mathrm{t}-1}$ & $\begin{array}{l}0,2420^{* * *} \\
(0,0649)\end{array}$ & $\begin{array}{l}0,2511^{* * *} \\
(0,0646)\end{array}$ & $\begin{array}{l}0,2416^{* * *} \\
(0,0649)\end{array}$ \\
\hline Caixa/ $\mathrm{K}_{\mathrm{t}-1}$ & $\begin{array}{l}-2,2850^{* * * *} \\
(0,3396)\end{array}$ & $\begin{array}{l}-2,4104^{* * *} \\
(0,3350)\end{array}$ & $\begin{array}{l}-2,2873^{\text {**** }} \\
(0,3398)\end{array}$ \\
\hline $\mathrm{CD}$ & $\begin{array}{l}0,2159 \\
(0,2770)\end{array}$ & & \\
\hline Conselho & & $\begin{array}{l}0,1514 \\
(0,2571)\end{array}$ & \\
\hline Diretor & & & $\begin{array}{l}0,2365 \\
(0,2722)\end{array}$ \\
\hline Pirâmide & $\begin{array}{l}0,8242^{* * *} \\
(0,1989)\end{array}$ & $\begin{array}{l}0,8110^{* * *} \\
(0,2003)\end{array}$ & $\begin{array}{l}0,8249^{* * *} \\
(0,1991)\end{array}$ \\
\hline Controle por Acordo entre Acionistas & $\begin{array}{l}0,1516 \\
(0,3774)\end{array}$ & $\begin{array}{l}0,1375 \\
(0,3780)\end{array}$ & $\begin{array}{l}0,1442 \\
(0,3781)\end{array}$ \\
\hline Controle Familiar & $\begin{array}{l}0,6549^{* *} \\
(0,2645)\end{array}$ & $\begin{array}{l}0,6526^{* *} \\
(0,2769)\end{array}$ & $\begin{array}{l}0,6480^{* *} \\
(0,2657)\end{array}$ \\
\hline Controle Estatal & $\begin{array}{l}0,3367 \\
(0,5560)\end{array}$ & $\begin{array}{l}0,3266 \\
(0,5553)\end{array}$ & $\begin{array}{l}0,3389 \\
(0,5568)\end{array}$ \\
\hline Controle Estrangeiro & $\begin{array}{l}1,1173^{* * *} \\
(0,3189)\end{array}$ & $\begin{array}{l}1,1126^{* * *} \\
(0,3193)\end{array}$ & $\begin{array}{l}1,1196^{* * *} \\
(0,3191)\end{array}$ \\
\hline Nivelgc & $\begin{array}{l}0,5645^{*} \\
(0,3091)\end{array}$ & $\begin{array}{l}0,5598^{*} \\
(0,3098)\end{array}$ & $\begin{array}{l}0,5614^{*} \\
(0,3092)\end{array}$ \\
\hline Número de Observações & 1690 & 1694 & 1693 \\
\hline Número de Firmas & 350 & 350 & 350 \\
\hline Graus de Liberdade & 10 & 10 & 10 \\
\hline Teste de Wald & 146,06 & 146,01 & 146,53 \\
\hline Teste da Razão da Verossimilhança & 274,63 & 277,47 & 275,9 \\
\hline
\end{tabular}

As variáveis conselho, diretor e $C D$, que identifica o maior acionista último que participa da direção e do conselho da firma, apresentaram parâmetros não significativos. Isso pode estar indicando que a presença do maior acionista último no conselho de administração 
e/ou na direção da firma podem não contribuir para elevar a probabilidade de a firma ser considerada restrita financeiramente.

Firmas com uma estrutura de propriedade piramidal apresentaram uma maior probabilidade de enfrentar restrições financeiras. Como este tipo de propriedade permite a existência de diferenças entre direitos de fluxo de caixa e direitos de voto, o acionista controlador pode manter o controle da firma com uma parcela mínima de direitos de fluxo de caixa. Isto pode causar desconfiança dos acionistas que deixariam de investir na firma, reduzindo a capacidade de investimento da mesma. Atting et al. (2002) encontraram resultados que confirmam o potencial de expropriação dos acionistas minoritários quando existe grande diferença entre os direitos de voto e de fluxo de caixa. Já Bianco e Casavola (1999) afirmaram que a presença da firma em uma estrutura de propriedade piramidal poderia facilitar a transferência de recursos entre as firmas pertencentes à estrutura. Desse forma, o modelo probabilístico logit pode estar evidenciando que caso haja transferência de recursos entre as firmas, esses recursos transferidos podem estar associados com a maximização do retorno do acionista controlador, e não com a realização de novos projetos de investimento. Esta transferência de recursos em benefício do acionista controlador pode ser entendida como uma maneira de se expropriar direitos dos acionistas minoritários por parte do acionista controlador da estrutura ${ }^{49}$.

A relação positiva e significativa das variáveis de controle estrangeiro e familiar com a probabilidade de restrição financeira mostra que firmas com esses tipos de natureza de propriedade e controle aumentam seu grau de restrição financeira quando o maior acionista último é o acionista controlador das firmas. Isto poderia estar relacionado à grande concentração de poder do acionista controlador sobre as decisões financeiras da firma que não estariam dispostos a reduzir o seu controle mesmo que este mecanismo fosse benéfico para o financiamento de novos projetos de investimento.

As variáveis controle por acordo entre acionistas e controle estatal obtiveram parâmetros não significativos, evidenciando que essas formas de controle podem não influenciar na probabilidade de a firma ser considerada restrita financeiramente. Estes resultados estão de acordo com as estatísticas descritas destas variáveis apresentadas na tabela 2, as quais mostraram que firmas estatais e firmas com controle por acordo entre acionistas

\footnotetext{
49 Essa transferência de recursos e resultados entre as firmas da estrutura de propriedade piramidal para beneficiar o acionista controlador é denominada na literatura por tunneling.
} 
estão igualmente distribuídas entre firmas consideradas restritas e não restritas financeiramente.

Embora fosse esperado que a adesão das firmas em um dos níveis diferenciados de governança corporativa e ao Novo Mercado contribuísse para reduzir o potencial de restrição financeira das firmas, a estimação do modelo logit evidenciou o contrário. Firmas que se inserem em um dos segmentos de listagem de governança corporativa aumentam sua probabilidade de serem consideradas restritas financeiramente. Como a criação dos segmentos de listagem foi realizada em 2001, as firmas necessitaram se adaptar para cumprir as exigências feitas pela BM\&FBOVESPA e se inserirem em um dos níveis diferenciados ou ao Novo Mercado. Dessa forma, a variável nivelgc pode estar captando estes custos adicionais para a adequação das firmas. Além disso, outra possível explicação para este parâmetro positivo pode estar relacionada ao período da amostra analisada. A amostra compreende o período de 1997 a 2007 e, o maior número de firmas que se inseriram a um dos segmentos de listagem foi no ano de 2006 e 2007. Assim, pode ser que a variável nivelgc não esteja capturando o possível aspecto positivo da adesão a um dos segmentos de listagem devido ao fato de que os recursos adquiridos seriam utilizados na execução de projetos de investimentos em períodos seguintes, não presentes na amostra.

Com o modelo probabilístico logit para dados em painel pôde-se analisar como mecanismos de governança corporativa interferem na probabilidade da firma ser considerada restrita financeiramente. Com o intuito de examinar como as características de governança corporativa influenciam nas decisões de investimento das firmas, utilizou-se uma versão modificada do modelo acelerador, estimada pelo Método dos Momentos Generalizados (GMM), considerando as firmas agrupadas entre restritas e não restritas financeiramente de acordo com o índice KZ. A tabela 7 apresenta os parâmetros estimados do modelo de investimento pelo método GMM.

Os resultados mostram que a variável fluxo de caixa $\left(F C / K_{t-1}\right)$ é significativa tanto para as firmas consideradas restritas quanto para as firmas não restritas financeiramente de acordo com o índice KZ. O parâmetro positivo desta variável para o grupo de firmas consideradas restritas financeiramente indica que estas firmas dependem de seus fundos internos para a realização de investimentos, visto que a medida que se aumenta o fluxo de caixa, eleva-se a taxa de investimento. Dado que essas firmas apresentaram melhores indicadores de rentabilidade $(R O A, L L / P L)$ em relação ao grupo de firmas consideradas restritas financeiramente, pode-se dizer que a variável fluxo de caixa não está sinalizando 
Tabela 7: Estimação GMM - Índice KZ

\begin{tabular}{|c|c|c|}
\hline \multirow{2}{*}{ Variáveis } & \multicolumn{2}{|c|}{ Estimação GMM - Índice KZ } \\
\hline & Firmas não Restritas & Firmas Restritas \\
\hline$\left(\mathrm{I} / \mathrm{K}_{\mathrm{t}-1}\right)_{\mathrm{i}, \mathrm{t}-1}$ & $\begin{array}{l}-0,0872^{* * *} \\
(0,0034)\end{array}$ & $\begin{array}{l}-0,2227^{* * *} \\
(0,0011)\end{array}$ \\
\hline$\left[\left(\mathrm{I} / \mathrm{K}_{\mathrm{t}-1}\right)_{\mathrm{i}, \mathrm{t}-1}\right]^{2}$ & $\begin{array}{l}0,0034^{* * *} \\
(0,0010)\end{array}$ & $\begin{array}{l}0,0084^{* * *} \\
(0,0004)\end{array}$ \\
\hline$\left(\mathrm{FC} / \mathrm{K}_{\mathrm{t}-1}\right)_{\mathrm{i}, \mathrm{t}}$ & $\begin{array}{l}0,0932^{* * *} \\
(0,0103)\end{array}$ & $\begin{array}{l}-0,6992^{* * *} \\
(0,0114)\end{array}$ \\
\hline$\left(\mathrm{D} / \mathrm{K}_{\mathrm{t}-1}\right)_{\mathrm{i}, \mathrm{t}}$ & $\begin{array}{l}0,0486^{* * *} \\
(0,0013)\end{array}$ & $\begin{array}{l}0,1689^{* * *} \\
(0,0006)\end{array}$ \\
\hline$\left(\mathrm{V} / \mathrm{K}_{\mathrm{t}-1}\right)_{\mathrm{i}, \mathrm{t}}$ & $\begin{array}{l}0,0362^{* * *} \\
(0,0007)\end{array}$ & $\begin{array}{l}0,0235^{* * *} \\
(0,0004)\end{array}$ \\
\hline Pirâmide $_{i, t}$ & $\begin{array}{l}0,0170^{* * *} \\
(0,0007)\end{array}$ & $\begin{array}{l}-0,1177^{* * *} \\
(0,0014)\end{array}$ \\
\hline Controle por Acordo entre Acionistas $\mathrm{i}_{\mathrm{i}, \mathrm{t}}$ & $\begin{array}{l}-0,0327^{* * *} \\
(0,0040)\end{array}$ & $\begin{array}{l}0,0508^{* * *} \\
(0,0057)\end{array}$ \\
\hline Controle Estatal $_{\mathrm{i}, \mathrm{t}}$ & $\begin{array}{l}0,0616 \\
(0,0570)\end{array}$ & $\begin{array}{l}0,0512^{* * * *} \\
(0,0116)\end{array}$ \\
\hline Controle Estrangeiro $_{i, t}$ & $\begin{array}{l}-0,0219^{* * * *} \\
(0,0082)\end{array}$ & $\begin{array}{l}0,1894^{* * *} \\
(0,0133)\end{array}$ \\
\hline Controle Familiar ${ }_{i, t}$ & $\begin{array}{l}-0,0615^{* * *} \\
(0,0006)\end{array}$ & $\begin{array}{l}0,0516^{* * *} \\
(0,0010)\end{array}$ \\
\hline $\mathrm{CD}_{\mathrm{i}, \mathrm{t}}$ & $\begin{array}{l}-0,0112^{* * *} \\
(0,0034)\end{array}$ & $\begin{array}{l}-0,0928^{* * *} \\
(0,0019)\end{array}$ \\
\hline$\left(\mathrm{FC} / \mathrm{K}_{\mathrm{t}-1}\right)_{\mathrm{i}, \mathrm{t}}$ * nivelgc & $\begin{array}{l}-0,0090^{* * *} \\
(0,0024)\end{array}$ & $\begin{array}{l}0,4132^{* * *} \\
(0,0318)\end{array}$ \\
\hline$\left(\mathrm{FC} / \mathrm{K}_{\mathrm{t}-1}\right)_{\mathrm{i}, \mathrm{t}} * \operatorname{dirfc}$ & $\begin{array}{l}-0,4995^{* * *} \\
(0,0054)\end{array}$ & $\begin{array}{l}-0,1221^{* * *} \\
(0,0065)\end{array}$ \\
\hline$\left(\mathrm{FC} / \mathrm{K}_{\mathrm{t}-1}\right)_{\mathrm{i}, \mathrm{t}} *$ dirvoto & $\begin{array}{l}0,3013^{* * *} \\
(0,0158)\end{array}$ & $\begin{array}{l}1,1059^{* * *} \\
(0,0193)\end{array}$ \\
\hline Número de Observações & 559 & 507 \\
\hline Número de Firmas & 162 & 180 \\
\hline Teste de Sargan & $0,4414^{(\mathrm{a})}$ & $0,3016^{(\mathrm{a})}$ \\
\hline Teste de Autocorrelação & & \\
\hline a) $1^{\mathrm{a}}$ Ordem & $0,1426^{(a)}$ & $0,0439^{(a)}$ \\
\hline b) $2^{\mathrm{a}}$ Ordem & $0,2276^{(a)}$ & $0,2213^{(a)}$ \\
\hline
\end{tabular}

Notas:Esta tabela reporta os resultados da equação em (11). A variável dependente é ( $\left(\mathrm{I} / \mathrm{K}_{\mathrm{t}-1}\right)$. A definição das variáveis é dada nos quadros do apêndice A. Os erros-padrão estão reportados entre parênteses. Os símbolos ( ${ }^{* * *}$ ) e $\left({ }^{a}\right)$ indicam, respectivamente, o nível de significância de $1 \%$ e os p-valores dos testes de Sargan e de Autocorrelação.

restrição financeira. Já para o grupo de firmas consideradas restritas, a variável fluxo de caixa obteve parâmetro negativo e significativo. Este resultado combinado com os baixos indicadores de rentabilidade permite concluir que, quando comparado com as firmas consideradas não restritas, firmas classificadas como restritas financeiramente não estariam 
sujeitas a crítica de que o fluxo de caixa estaria sinalizando potencial para a rentabilidade futura. Assim, a variável fluxo de caixa estaria indicando a presença da restrição financeira nas firmas consideradas restritas financeiramente pelo índice KZ. Além disso, o parâmetro negativo desta variável mostra que a elevação do fluxo de caixa reduz a taxa de investimento. Assim, visto que as firmas consideradas restritas exibiram média negativa para o lucro operacional em razão do estoque de capital, o parâmetro negativo da variável fluxo de caixa pode ser explicado de maneira semelhante ao do estudo de Baghat et al. (2005). De acordo com esses autores, firmas com dificuldades financeiras e com perdas operacionais apresentaram sensibilidade negativa do investimento ao fluxo de caixa. Isso se deve a continuação das atividades das firmas mesmo havendo perdas operacionais, isto é, mesmo que suas atividades não sejam suficientes para cobrir seus gastos com produção, firmas com dificuldades financeiras continuariam investindo na esperança de obter melhor desempenho operacional futuro.

O coeficiente da variável dívida total como razão do estoque de capital $\left(D / K_{t-1}\right)$ mostrou-se significativo e positivo para os dois grupos de firmas. Firmas consideradas restritas obtiveram maior parâmetro $(0,1689)$ em relação às firmas consideradas não restritas, cujo parâmetro foi de 0,0486 . O maior coeficiente para as firmas consideradas restritas pode estar indicando a maior dependência da dívida para a realização de investimentos. Entretanto, essa dependência em relação ao mercado externo também pode ser interpretada como um mecanismo disciplinador sobre os gestores, os quais, preocupados em gerar fundos suficientes para pagar o compromisso da dívida, diminuiriam a possibilidade de implementação de projetos de investimentos não lucrativos e, portanto problemas de assimetria de informação entre gestores e acionistas seriam reduzidos (TIROLE, 2006).

A variável vendas $\left(V / K_{t-1}\right)$ apresentou-se significativa para ambos grupos de firmas. $\mathrm{O}$ seu valor positivo indica uma relação positiva entre investimento e volume de vendas, mostrando que um aumento no nível de vendas contribui para elevar a taxa de investimento das firmas.

Com o intuito de analisar como as naturezas de controle e de propriedade interferem na decisão de investimento das firmas, considerou-se na estimação do modelo em (11) a estrutura de propriedade piramidal e as principais naturezas de propriedade e controle, ou seja, acordo entre acionistas, estatal, estrangeira e familiar. Dessa forma, considerando a estrutura de propriedade piramidal, firmas classificadas como restritas financeiramente obtiveram um parâmetro negativo para a variável pirâmide, enquanto que firmas consideradas não restritas apresentaram um parâmetro positivo. Isso mostra que firmas classificadas como não restritas 
elevam sua taxa de investimento quando estão inseridas em uma estrutura de propriedade piramidal, ao passo que firmas consideradas restritas financeiramente reduzem sua taxa de investimento. Esta inversão de sinais dos parâmetros pode estar indicando que apenas pertencer a uma estrutura de propriedade piramidal não é suficiente para constatar a transferência de recursos dentro da pirâmide que aliviem as restrições financeiras. Pode ser que o alto endividamento em relação ao patrimônio líquido apresentado pelo grupo de firmas consideradas restritas financeiramente dificulte as demais firmas pertencentes à pirâmide a conceder recursos, visto que a possibilidade de falência e o não pagamento do empréstimo poderiam comprometer as demais firmas inseridas na pirâmide.

Firmas consideradas restritas financeiramente elevam sua taxa de investimento quando são controladas por acordo entre acionistas, Estado, acionistas estrangeiros ou familiares. Esta elevação ocorre principalmente quando este controle é de origem estrangeira $(0,1894)$. Schaller (1993) mostrou que firmas com alta concentração de propriedade são menos dependentes do fluxo de caixa do que firmas com propriedade diversificada. O autor explicou que isso se devia à redução dos conflitos de agência entre gestores e acionistas, o que diminuiria os custos de agência e elevaria os investimentos da firma. Já para as firmas não restritas financeiramente, os resultados mostraram que o controle por acordo entre acionistas, familiar e estrangeiro reduzem o investimento das firmas. Isso pode estar indicando que a presença do acionista controlador para firmas não restritas financeiramente é entendido como um mecanismo facilitador para a expropriação de recursos dos acionistas externos, implicando em uma elevação nos custos de agência e, consequentemente, na redução dos investimentos das firmas.

A introdução da variável $C D$ no modelo em (11) teve como objetivo testar como a presença do maior acionista último no conselho de administração e na direção da firma interfere nas decisões de investimento. Nota-se que esta variável apresenta-se significativa e negativa para os dois grupos de firmas. Isso implica que a atuação do maior acionista último como diretor e a presença do maior acionista último no conselho administrativo, isto é, a presença de membros não independentes no conselho, diminui a capacidade de investimentos da firma. Este fato pode estar relacionado ao descumprimento das funções básicas do conselho, ou seja, o não monitoramento dos gestores em favor dos acionistas e amenização de problemas de agência, corroborando com o estudo de Setia-Atmaja (2009).

A variável de interação entre o fluxo de caixa e o nível de governança corporativa $\left(F C / K_{t-1}\right)_{i, t} *$ nivelgc foi significativa para ambos os grupos. Para as firmas consideradas não restritas financeiramente, esta variável obteve parâmetro negativo, indicando que estas firmas 
reduzem sua sensibilidade do investimento ao fluxo de caixa, quando estão inseridas em um dos segmentos de listagem de governança corporativa. Isso implica dizer que estar em um dos níveis de governança corporativa da BM\&FBOVESPA ou no Novo Mercado contribui para reduzir a necessidade de fundos internos para a realização de investimentos, o que pode estar associado a uma melhor avaliação do mercado sobre as firmas inseridas nos níveis diferenciados. Entretanto, o mesmo não foi observado para as firmas consideradas restritas. Para esse grupo de firmas, a sensibilidade do investimento ao fluxo de caixa é elevada quando as firmas estão presentes em um dos segmentos de listagem de governança corporativa. Dessa forma, para as firmas restritas financeiramente, apenas estar inserida em um dos níveis diferenciados ou no Novo Mercado não é suficiente para reduzir a dependência de fundos internos na realização de investimentos. Para serem inseridas em um dos segmentos de listagem de governança corporativa, as firmas devem cumprir uma série de exigências feitas pela BM\&FBOVESPA, tais como: melhoria nas divulgações financeiras, conselho de administração com no mínimo cinco membros, adesão à Câmara de Arbitragem, proibição de ações preferenciais - caso a firma queira aderir ao Novo Mercado, dentre outras, que geram custos e podem dificultar o acesso e até mesmo a manutenção das firmas nos níveis diferenciados de governança corporativa, principalmente para firmas com situação financeira ruim e com alto grau de alavancagem, o que explicaria o sinal positivo desta variável para o grupo de firmas consideradas restritas financeiramente.

A variável de interação entre o fluxo de caixa e os direitos de fluxo de caixa do maior acionista último $\left(F C / K_{t-1}\right)_{i, t} * \operatorname{dirfc}$ apresentou sinal negativo e significativo tanto para as firmas consideradas restritas quanto para as firmas não restritas financeiramente. $\mathrm{O}$ sinal negativo desta variável indica que o aumento nos direitos de fluxo de caixa do maior acionista último reduz a sensibilidade do investimento ao fluxo de caixa. Dessa forma, pode-se dizer que uma elevação nos direitos de fluxo de caixa do maior acionista último contribui para diminuir a dependência das firmas em relação à disponibilidade de fundos internos para a realização de investimentos. Além disso, como a elevação dos direitos de fluxo de caixa está associada a uma maior participação do maior acionista último no capital da firma, que por consequiência, pode estar relacionada aos interesses dos grandes acionistas, estes acionistas tenderiam a melhor fiscalizar as atividades dos gestores e reduzir assimetrias de informação.

Já a variável de interação entre o fluxo de caixa e os direitos de voto do maior acionista último $\left(F C / K_{t-1}\right)_{i, t} *$ dirvoto foi positiva e significativa para ambos os grupos. Isso indica que o aumento dos direitos de voto do maior acionista último eleva a sensibilidade do investimento ao fluxo de caixa, principalmente para as firmas consideradas financeiramente 
restritas que obtiveram um maior parâmetro $(1,1059)$ em relação às firmas consideradas não restritas financeiramente (0,3013). Assim, o aumento na concentração de votos por parte deste acionista propicia um aumento na dependência do fluxo de caixa para se realizar novos investimentos. Dessa forma, essa variável de interação mostra o efeito negativo da concentração de votos sobre o acesso ao financiamento no mercado externo, pois, sob certa concentração de propriedade, grandes acionistas estariam mais preocupados em obter benefícios privado de controle em detrimento dos demais acionistas, ou seja, com uma maior concentração de votos, a probabilidade de expropriação de riquezas dos acionistas minoritários aumentaria. Com isso, se elevaria os custos de agência ou se reduziria a quantidade de recursos advindos dos acionistas minoritários, afetando o caixa e contribuindo para aumentar a sensibilidade do investimento ao fluxo de caixa.

A próxima seção apresenta as estimativas e as interpretações do modelo em (11) estimado pelo GMM, agrupando-se as firmas por tamanho e por pagamento de dividendos.

\subsection{Governança Corporativa, Pagamento de Dividendos e Tamanho da firma.}

Apesar do grande número de estudos que utilizam o pagamento de dividendos e o tamanho da firma para classificar a amostra em grupos que possibilite identificar a presença da restrição financeira, não existe ainda uma conclusão definitiva se firmas de pequeno porte ou que não distribuem dividendos sejam restritas financeiramente. Afim de contribuir para esta literatura e examinar a robustez da estimação do GMM para as firmas agrupadas segundo o índice KZ, considerou-se a classificação das firmas tanto por pagamento de dividendos quanto por tamanho.

Para classificar as firmas de acordo com o tamanho, adotou-se a mediana do ativo total como ponto de corte para delimitar os grupos. Dessa forma, firmas com ativo total menor do que a mediana foram consideradas de tamanho pequeno e, firmas com ativo total maiores ou iguais a mediana foram consideradas de tamanho grande. Assim, espera-se que firmas de menor tamanho dependam mais de seus fundos internos para realizar investimentos, como evidenciado por diversos estudos, tais como os de Gilchrist e Himmelberg (1995), Almeida e Campello (2004) e Denis e Sibilov (2010). Para esses estudos, firmas de menor porte teriam mais chance de serem restritas financeiramente, já que estas firmas tenderiam a enfrentar maiores dificuldades para obter financiamento a um baixo custo no mercado externo, além de serem geralmente jovens e menos conhecidas no mercado. 
Já para se agrupar as firmas segundo o pagamento de dividendos, seguiu-se Ginglinger e Saddour (2007), as quais consideraram o fato de pagar ou não dividendos como uma forma de classificar as firmas. Assim, dois grupos de firmas foram criados: firmas que pagam qualquer quantidade de dividendos e, firmas que não distribuem dividendos. Dado que uma das finalidades do pagamento de dividendos é a redução dos custos de agência, e consequentemente, a diminuição do fluxo de caixa livre que poderia ser utilizado em investimentos não lucrativos, espera-se que firmas que distribuem dividendos sejam não restritas financeiramente, corroborando assim, com os estudos empíricos presentes na literatura. Fazzari et al. (1988), Almeida e Campello (2004), e Saddour (2007), dentre outros autores, obtiveram resultados que indicam que firmas com menor taxa de pagamento de dividendos sejam restritas financeiramente.

A tabela 8 apresenta as estatísticas descritivas para os grupos de firmas classificadas por tamanho e para o agrupamento por pagamento de dividendos.

Tabela 8: Estatísticas Descritivas - Pagamento de Dividendos e Tamanho

\begin{tabular}{|c|c|c|c|c|c|c|c|c|}
\hline \multirow{3}{*}{ Indicadores } & \multicolumn{4}{|c|}{ Pagamento de Dividendos } & \multicolumn{4}{|c|}{ Tamanho da Firma } \\
\hline & \multicolumn{2}{|c|}{ Div $=0$} & \multicolumn{2}{|c|}{ Div $>0$} & \multicolumn{2}{|c|}{ Pequeno } & \multicolumn{2}{|c|}{ Grande } \\
\hline & Média & $\begin{array}{l}\text { Desvio } \\
\text { Padrão }\end{array}$ & Média & $\begin{array}{l}\text { Desvio } \\
\text { Padrão }\end{array}$ & Média & $\begin{array}{l}\text { Desvio } \\
\text { Padrão }\end{array}$ & Média & $\begin{array}{l}\text { Desvio } \\
\text { Padrão }\end{array}$ \\
\hline $\mathrm{I} / \mathrm{K}_{\mathrm{t}-1}$ & 0,0299 & 0,4625 & 0,0408 & 0,3469 & 0,0109 & 0,3848 & 0,0587 & 0,4096 \\
\hline $\mathrm{FC} / \mathrm{K}_{\mathrm{t}-1}$ & 0,0926 & 0,4680 & 0,3392 & 0,4299 & 0,2310 & 0,5768 & 0,2450 & 0,3363 \\
\hline Caixa/K $\mathrm{K}_{\mathrm{t}-1}$ & 0,2611 & 0,8007 & 0,4625 & 0,9002 & 0,4021 & 0,9801 & 0,3498 & 0,7403 \\
\hline FCL/V & 0,0282 & 2,1995 & 0,2157 & 0,6825 & 0,0920 & 1,8820 & 0,1906 & 0,9628 \\
\hline $\mathrm{V} / \mathrm{K}_{\mathrm{t}-1}$ & 2,4115 & 3,4827 & 3,5509 & 5,4450 & 3,8550 & 5,7453 & 2,3420 & 3,4487 \\
\hline $\mathrm{AT}$ & $1,86 \mathrm{E}+06$ & $3,82 \mathrm{E}+06$ & $6,27 \mathrm{E}+06$ & $1,98 \mathrm{E}+07$ & $3,08 \mathrm{E}+05$ & $2,52 \mathrm{E}+05$ & $8,13 \mathrm{E}+06$ & $2,03 \mathrm{E}+07$ \\
\hline $\mathrm{ELP} / \mathrm{K}_{\mathrm{t}-1}$ & 0,9828 & 1,3276 & 0,7150 & 0,8235 & 0,7912 & 1,1698 & 0,8564 & 0,9723 \\
\hline $\mathrm{PC} / \mathrm{K}_{\mathrm{t}-1}$ & 1,1665 & 1,5547 & 1,1740 & 1,7243 & 1,3578 & 1,7480 & 0,9941 & 1,5345 \\
\hline $\mathrm{D} / \mathrm{K}_{\mathrm{t}-1}$ & 2,1493 & 2,3697 & 1,8890 & 2,1494 & 2,1489 & 2,3486 & 1,8505 & 2,1307 \\
\hline D/AT & 0,5861 & 0,2397 & 0,4904 & 0,1814 & 0,5019 & 0,2441 & 0,5685 & 0,1769 \\
\hline $\mathrm{D} / \mathrm{PL}$ & 3,4161 & 4,4321 & 1,5799 & 1,8845 & 2,3171 & 3,5973 & 2,5635 & 3,3495 \\
\hline ROA & $-0,0235$ & 0,1367 & 0,0544 & 0,0797 & 0,0053 & 0,1459 & 0,0308 & 0,0745 \\
\hline LL/PL & $-0,1648$ & 0,6196 & 0,1071 & 0,2592 & $-0,0897$ & 0,5709 & 0,0468 & 0,3666 \\
\hline $\mathrm{LO} / \mathrm{K}_{\mathrm{t}-1}$ & $-0,0624$ & 0,6865 & 0,2684 & 0,4762 & 0,0950 & 0,7807 & 0,1549 & 0,3536 \\
\hline $\begin{array}{l}\text { Número } \\
\text { de Firmas }\end{array}$ & \multicolumn{2}{|c|}{1367} & \multicolumn{2}{|c|}{1541} & \multicolumn{2}{|c|}{1433} & \multicolumn{2}{|c|}{1433} \\
\hline
\end{tabular}

Nota-se por esta tabela que firmas com pagamento de dividendos investiram e venderam mais do que firmas que não pagam dividendos. Além disso, essas firmas também apresentaram fluxo de caixa, em média, três vezes superior ao de firmas que não distribuem 
dividendos. No entanto, embora fosse esperado que firmas que pagam dividendos tenham menor quantidade de caixa e fluxo de caixa livre, os indicadores mostraram o contrário, ou seja, firmas que pagam dividendos a seus acionistas apresentaram fluxo de caixa livre e disponível superiores ao de firmas que não pagam dividendos. Isso pode estar indicando que mesmo distribuindo dividendos, essas firmas mantêm reservas de caixa e de fluxo de caixa livre para possíveis momentos de restrições de liquidez.

A tabela 8 também evidencia que firmas que distribuem dividendos possuem tamanho, em média, mais do que três vezes maior do que as firmas que não pagam dividendos. Ademais, firmas com pagamento de dividendos recorrem menos ao financiamento externo quando comparadas com as firmas que não distribuem dividendos. Este fato pode ser observado pelas variáveis $E L P / K_{t-1}$ e $D / K_{t-1}$, que mensuram o financiamento de longo prazo e a dívida total em razão do estoque de capital. Entretanto, não se observa diferenças significativas em relação ao financiamento de curto prazo quando se compara a variável $P C / K_{t-l}$ entre os grupos de firmas classificadas de acordo com o pagamento de dividendos.

Firmas sem pagamento de dividendos possuem maior dívida em razão do estoque de capital $\left(D / K_{t-1}\right)$ do que firmas que distribuem dividendos. Quando a dívida total é relacionada com o ativo total (D/AT), firmas que não pagam dividendos ainda apresentaram um maior endividamento em relação às firmas que distribuem dividendos. Contudo, o grau de alavancagem das firmas sem pagamento de dividendos eleva-se ainda mais quando a dívida é comparada com seu patrimônio líquido $(D / P L)$. Firmas que não distribuem dividendos possuem, em média, um endividamento três vezes maior do que seu patrimônio líquido, ao passo que firmas com pagamento de dividendos apresentaram uma razão de 1,58 para esta variável.

A razão entre lucro líquido e ativo total $(R O A)$, e a razão entre lucro líquido e patrimônio líquido $(L L / P L)$ para firmas com pagamento de dividendos mostraram-se superiores ao de firmas que não distribuem dividendos, sendo que as últimas apresentaram valores negativos para estas variáveis. Além disso, o índice de rentabilidade operacional, medido pelo $L O / K_{t-1}$, também apresentou média negativa para as firmas que não distribuem dividendos, e média positiva para o outro grupo de firmas.

Enfim, constatou-se por essa análise que firmas com pagamento de dividendos possuem maior tamanho e recorrem menos ao endividamento do que firmas que não distribuem dividendos. Isso pode estar indicando que com o pagamento de dividendos as firmas obtêm maior financiamento por meio da dívida, elevando sua taxa de investimento e melhorando seus níveis de vendas e seus índices de rentabilidade. Esses resultados são 
semelhantes ao encontrado por Cleary (2006) que, analisando as firmas de acordo com o pagamento de dividendos, identificou uma maior concentração de firmas de grande porte e melhor situação financeira entre esse grupo de firmas.

Considerando as firmas classificadas pelo tamanho, a tabela 8 mostra que firmas com tamanho grande apresentaram taxa de investimento 5,4 vezes maior que firmas de tamanho pequeno. Já em relação à variável fluxo de caixa $\left(F C / K_{t-1}\right)$, em média, não há diferenças entre os grupos de firmas. Embora haja pouca diferença entre as médias da variável disponível $\left(\right.$ Caixa $\left./ K_{t-1}\right)$, aparentemente firmas de menor tamanho possuem maior quantidade de caixa e investimentos de curto prazo quando comparadas com as firmas de maior tamanho. Entretanto, firmas de maior tamanho possuem, em média, fluxo de caixa livre $(F C L / V)$ cerca de duas vezes maior do que firmas pequenas.

Firmas de maior tamanho apresentaram mais dívida de longo prazo $\left(E L P / K_{t-1}\right)$ do que firmas pequenas. Em contrapartida, firmas de tamanho pequeno possuem mais dívida de curto prazo $\left(P C / K_{t-1}\right)$. Isso pode estar associado ao fato de que firmas de maior tamanho, geralmente, são mais conhecidas no mercado, podendo-lhe oferecer garantias sobre a qualidade do crédito do tomador do empréstimo. Dessa forma, firmas maiores obteriam financiamentos de longo prazo com um custo menor do que as firmas pequenas, que normalmente são firmas jovens e menos conhecidas no mercado. Esse maior financiamento de curto prazo para as firmas pequenas está se refletindo sobre a dívida total em razão com estoque de capital $\left(D / K_{t-1}\right)$ que, para esse grupo de firmas, chega a ser $16 \%$ maior do que o endividamento das firmas grandes. No entanto, embora se observe pouca diferença entre as médias das variáveis que analisam o endividamento em relação ao ativo total $(D / A T)$ e ao patrimônio líquido $(D / P L)$, firmas grandes obtiveram maiores médias para essas variáveis quando comparadas com as firmas pequenas.

Em relação aos índices de rentabilidade medidos pelas variáveis $R O A$ e $L L / P L$, firmas maiores possuem, em média, ROA 5,8 vezes maior do que firmas de tamanho pequeno. Já para a razão entre lucro líquido e patrimônio líquido, firmas menores apresentaram médias negativas, mostrando-se inferior ao de firmas grandes, que apresentaram média positiva. Firmas de maior tamanho também apresentaram maior índice de rentabilidade operacional $\left(L O / K_{t-1}\right)$ quando comparado ao de firmas menores.

Com as firmas classificadas de acordo com o tamanho e o pagamento de dividendos, pôde-se analisar as características financeiras dos grupos de firmas. Assim, para investigar o comportamento do investimento considerando a presença da restrição financeira e os mecanismos de governança corporativa, o modelo de investimento foi estimado pelo método 
GMM para cada um dos grupos. A tabela 9 apresenta a estimação do modelo em (11) controlando-se por tamanho e por pagamento de dividendos.

Tabela 9: Estimação GMM - Pagamento de Dividendos e Tamanho da Firma

\begin{tabular}{|c|c|c|c|c|}
\hline \multirow{3}{*}{ Variáveis } & \multicolumn{4}{|c|}{ Firmas divididas em grupos } \\
\hline & \multicolumn{2}{|c|}{$\begin{array}{l}\text { Pagamento de } \\
\text { Dividendos } \\
\end{array}$} & \multicolumn{2}{|c|}{ Tamanho } \\
\hline & $\operatorname{Div}=0$ & Div $>0$ & Pequeno & Grande \\
\hline$\left(\mathrm{I} / \mathrm{K}_{\mathrm{t}-1}\right)_{\mathrm{i}, \mathrm{t}-1}$ & $\begin{array}{l}-0,0807^{* * *} \\
(0,0021)\end{array}$ & $\begin{array}{c}-0,1682^{* * *} \\
(0,0061)\end{array}$ & $\begin{array}{l}0,0448^{* * *} \\
(0,0004)\end{array}$ & $\begin{array}{c}-0,1636^{* * *} \\
(0,0009)\end{array}$ \\
\hline$\left[\left(\mathrm{I} / \mathrm{K}_{\mathrm{t}-1}\right)_{\mathrm{i}, \mathrm{t}-1}\right]^{2}$ & $\begin{array}{c}-0,0287^{* * *} \\
(0,0009)\end{array}$ & $\begin{array}{l}0,0084^{* * *} \\
(0,0030)\end{array}$ & $\begin{array}{c}-0,0627^{* * *} \\
(0,0002)\end{array}$ & $\begin{array}{l}0,0169^{\text {*** }} \\
(0,0005)\end{array}$ \\
\hline$\left(\mathrm{FC} / \mathrm{K}_{\mathrm{t}-1}\right)_{\mathrm{i}, \mathrm{t}}$ & $\begin{array}{c}-0,8589^{* * *} \\
(0,0127)\end{array}$ & $\begin{array}{l}0,4786^{* * *} \\
(0,0307)\end{array}$ & $\begin{array}{c}-0,3316^{* * *} \\
(0,0034)\end{array}$ & $\begin{array}{c}0,0089 \\
(0,0115)\end{array}$ \\
\hline$\left(\mathrm{D} / \mathrm{K}_{\mathrm{t}-1}\right)_{\mathrm{i}, \mathrm{t}}$ & $\begin{array}{l}0,1422^{* * *} \\
(0,0012)\end{array}$ & $\begin{array}{l}0,1065^{* * *} \\
(0,0044)\end{array}$ & $\begin{array}{l}0,0905^{* * *} \\
(0,0007)\end{array}$ & $\begin{array}{l}0,1744^{* * *} \\
(0,0008)\end{array}$ \\
\hline$\left(\mathrm{V} / \mathrm{K}_{\mathrm{t}-1}\right)_{\mathrm{i}, \mathrm{t}}$ & $\begin{array}{l}0,0361^{* * *} \\
(0,0006)\end{array}$ & $\begin{array}{c}0,0137^{* * *} \\
(0,0021)\end{array}$ & $\begin{array}{l}0,0163^{* * *} \\
(0,0002)\end{array}$ & $\begin{array}{l}0,0254^{* * *} \\
(0,0003)\end{array}$ \\
\hline Pirâmide $_{i, t}$ & $\begin{array}{l}-0,0144^{* * *} \\
(0,0020)\end{array}$ & $\begin{array}{c}-0,0129^{* * *} \\
(0,0027)\end{array}$ & $\begin{array}{c}-0,0387^{* * *} \\
(0,0005)\end{array}$ & $\begin{array}{l}0,0036^{* * *} \\
(0,0004)\end{array}$ \\
\hline Controle por Acordo entre Acionistas ${ }_{i, t}$ & $\begin{array}{l}0,0165^{* * *} \\
(0,0020)\end{array}$ & $\begin{array}{l}0,0270^{* * *} \\
(0,0096)\end{array}$ & $\begin{array}{l}-0,0057 \\
(0,0039)\end{array}$ & $\begin{array}{c}-0,0271^{* * *} \\
(0,0015)\end{array}$ \\
\hline Controle Estatal $_{\mathrm{i}, \mathrm{t}}$ & $\begin{array}{l}0,8712^{* * *} \\
(0,0143)\end{array}$ & $\begin{array}{l}-0,0406 \\
(0,0591)\end{array}$ & $\begin{array}{l}2,1084^{* * *} \\
(0,0110)\end{array}$ & $\begin{array}{l}-0,0150 \\
(0,0117)\end{array}$ \\
\hline Controle Estrangeiro $_{\mathrm{i}, \mathrm{t}}$ & $\begin{array}{l}0,2132^{* * *} \\
(0,0092)\end{array}$ & $\begin{array}{c}0,0028 \\
(0,0145)\end{array}$ & $\begin{array}{l}0,3685^{* * *} \\
(0,0024)\end{array}$ & $\begin{array}{c}0,0006 \\
(0,0027)\end{array}$ \\
\hline Controle Familiar $_{i, t}$ & $\begin{array}{c}0,0079 \\
(0,0062)\end{array}$ & $\begin{array}{l}-0,0019 \\
(0,0019)\end{array}$ & $\begin{array}{c}-0,0558^{* * *} \\
(0,0020)\end{array}$ & $\begin{array}{c}0,0677^{* * *} \\
(0,0011)\end{array}$ \\
\hline $\mathrm{CD}_{\mathrm{i}, \mathrm{t}}$ & $\begin{array}{c}0,0284^{* * *} \\
(0,0052)\end{array}$ & $\begin{array}{c}-0,0602^{\text {**** }} \\
(0,0123)\end{array}$ & $\begin{array}{l}0,0021^{* *} \\
(0,0010)\end{array}$ & $\begin{array}{c}0,0577^{* * *} \\
(0,0030)\end{array}$ \\
\hline$\left(\mathrm{FC} / \mathrm{K}_{\mathrm{t}-1}\right)_{\mathrm{i}, \mathrm{t}} *$ nivelgc & $\begin{array}{l}0,1320^{* * * *} \\
(0,0459)\end{array}$ & $\begin{array}{l}-0,0081 \\
(0,0295)\end{array}$ & $\begin{array}{c}0,2124^{\text {*** }} \\
(0,0052)\end{array}$ & $\begin{array}{c}-0,1206^{* * *} \\
(0,0058)\end{array}$ \\
\hline$\left(\mathrm{FC} / \mathrm{K}_{\mathrm{t}-1}\right)_{\mathrm{i}, \mathrm{t}} * \operatorname{dirfc}$ & $\begin{array}{c}-0,4491^{* * *} \\
(0,0106)\end{array}$ & $\begin{array}{c}-0,1066^{* * *} \\
(0,0192)\end{array}$ & $\begin{array}{c}0,0886^{\text {**** }} \\
(0,0021)\end{array}$ & $\begin{array}{c}-0,6019^{* * *} \\
(0,0052)\end{array}$ \\
\hline$\left(\mathrm{FC} / \mathrm{K}_{\mathrm{t}-1}\right)_{\mathrm{i}, \mathrm{t}} *$ dirvoto & $\begin{array}{l}1,4145^{\text {**** }} \\
(0,0237)\end{array}$ & $\begin{array}{c}-0,4622^{* * *} \\
(0,0471)\end{array}$ & $\begin{array}{c}0,2701^{\text {**** }} \\
(0,0046)\end{array}$ & $\begin{array}{c}0,5766^{* * *} \\
(0,0145)\end{array}$ \\
\hline Número de Observações & 457 & 865 & 585 & 741 \\
\hline Número de Firmas & 166 & 210 & 139 & 166 \\
\hline Teste de Sargan & 0,2200 & 0,2440 & 0,8007 & 0,2572 \\
\hline \multicolumn{5}{|l|}{ Teste de Autocorrelação } \\
\hline a) $1^{\mathrm{a}}$ Ordem & 0,0348 & 0,0241 & 0,0205 & 0,0383 \\
\hline b) $2^{a}$ Ordem & 0,6257 & 0,5148 & 0,3086 & 0,6668 \\
\hline
\end{tabular}

Notas: Esta tabela reporta os resultados da equação em (11). A variável dependente é $\left(\mathrm{I} / \mathrm{K}_{\mathrm{t}-1}\right)$. A definição das variáveis é dada nos quadros do apêndice A. Os erros-padrão estão reportados entre parênteses. Os símbolos $\left({ }^{* * *}\right)$ e $\left({ }^{\mathrm{a}}\right)$ indicam, respectivamente, o nível de significância de $1 \%$ e os p-valores dos testes de Sargan e de Autocorrelação. 
Os resultados mostraram que a variável fluxo de caixa $\left(F C / K_{t-1}\right)$ é significativa tanto para as firmas com pagamento de dividendos quanto para as firmas que não distribuem dividendos. Firmas que pagam dividendos apresentaram um parâmetro positivo para esta variável, o que evidencia que este grupo de firmas depende de seus fundos internos para a realização de investimentos. Assim, considerando os indicadores de rentabilidade apresentados na tabela 8 , tem-se que firmas com pagamento de dividendos possuem melhores índices de rentabilidade quando comparadas com as firmas que não distribuem dividendos, evidenciando que neste caso, a variável fluxo de caixa não está sinalizando restrição financeira. Já para o grupo de firmas que não distribuem dividendos, o parâmetro da variável fluxo de caixa foi negativo e significativo. Isso indica que a medida que se eleva o fluxo de caixa, a taxa de investimento das firmas é reduzida. Dessa forma, considerando os baixos indicadores de rentabilidade para este grupo de firmas em relação às firmas com pagamento de dividendos, a variável fluxo de caixa estaria sinalizando a presença da restrição financeira para firmas que não distribuem dividendos. Visto que esse grupo de firmas também apresentou média negativa para o lucro operacional, pode-se notar que este resultado é semelhante aos resultados apresentados na classificação pelo índice KZ para as firmas consideradas restritas financeiramente.

A variável vendas $\left(V / K_{t-1}\right)$ apresentou parâmetro positivo e significativo tanto para firmas com pagamento de dividendos quanto para firmas que não distribuem dividendos. A variável dívida total $\left(D / K_{t-1}\right)$ também obteve parâmetros positivos e significativos para ambos os agrupamentos, entretanto, firmas que não distribuem dividendos apresentaram maior parâmetro $(0,1422)$ em relação às firmas que pagam dividendos $(0,1065)$, o que evidencia que as primeiras dependem mais do financiamento externo para elevar sua taxa de investimento.

A variável pirâmide, que identifica se a firma possui estrutura de propriedade piramidal, apresentou parâmetros negativos e significativos para ambos os grupos classificados de acordo com o pagamento de dividendos. Isso mostra que indiferentemente se a firma distribui dividendos ou não, seus investimentos serão reduzidos quando a firma pertencer a uma estrutura de propriedade piramidal.

A variável controle por acordo entre acionistas foi positiva e significativa para ambos os grupos classificados de acordo com o pagamento de dividendos. Isso mostra que o controle por acordo entre acionistas eleva a taxa de investimento das firmas mesmo que estas não distribuam seus dividendos. Quando se considera as variáveis controle estatal e controle estrangeiro, observa-se que estas variáveis foram positivas e significativas apenas para as firmas que não distribuem dividendos, o que evidencia que essas naturezas de controle 
contribuem para aumentar a taxa de investimento das firmas. Já a variável que identifica a natureza familiar de controle apresentou parâmetro não significativo para ambos os grupos. Portanto, temos que firmas que não distribuem seus dividendos elevam sua taxa de investimento quando são controladas pelo seu maior acionista último.

A variável $C D$, que identifica a presença do maior acionista último como membro do conselho de administração e como diretor da firma mostrou-se significativa para firmas com e sem pagamento de dividendos. Firmas que não distribuem dividendos elevam sua taxa de investimento quando o maior acionista último está presente no conselho e na direção, enquanto que firmas com pagamento de dividendos reduzem seus investimentos com essa participação do maior acionista último nas firmas.

A variável de interação entre o fluxo de caixa e o nível de governança corporativa $\left(F C / K_{t-1}\right)_{i, t} *$ nivelgc apresentou-se significativa para ambos os grupos de firmas classificadas de acordo com a taxa de pagamento de dividendos. Para firmas que não distribuem dividendos, esta variável mostrou-se positiva, indicando que pertencer a um dos níveis diferenciados de governança corporativa da BM\&FBOVESPA ou ao Novo Mercado aumenta a sensibilidade do investimento ao fluxo de caixa. Em outras palavras, quando as firmas que não pagam dividendos estão inseridas em um dos segmentos de listagem, a dependência de seus fundos internos para a realização de investimento é elevada. Já para as firmas com pagamento de dividendos, essa variável de interação com o fluxo de caixa apresentou parâmetro negativo, evidenciando que pertencer a um dos segmentos de listagem de governança corporativa contribui para reduzir a dependência do fluxo de caixa de firmas que distribuem dividendos.

A variável de interação entre o fluxo de caixa e os direitos de fluxo de caixa do maior acionista último $\left(F C / K_{t-1}\right)_{i, t} * \operatorname{dirfc}$ obteve parâmetro negativo e significativo tanto para as firmas com pagamento de dividendos quanto para as firmas que não distribuem dividendos. Isso mostra que para cada aumento nos direitos de fluxo de caixa do maior acionista último, a sensibilidade do investimento ao fluxo de caixa é diminuída em 0,4491 para as firmas que não distribuem dividendos e 0,1066 para as firmas com pagamento de dividendos, mantendo fixas as demais variáveis. Dessa forma, tem-se que a maior participação do maior acionista último no capital da firma contribui para reduzir a dependência de recursos internos para a realização de investimentos, principalmente para o grupo de firmas que não pagam dividendos, que apresentaram menor parâmetro.

Já a variável de interação entre o fluxo de caixa e os direitos de voto do maior acionista último $\left(F C / K_{t-1}\right)_{i, t} *$ dirvoto apresentou parâmetros significativos mas com sinais 
distintos entre os grupos. Firmas que não distribuem dividendos obtiveram parâmetro positivo, evidenciando que a maior concentração de votos por parte do maior acionista último contribui para reduzir a dependência de fundos internos, e consequentemente, elevar a taxa de investimento dessas firmas. Contudo, quando a firma distribui dividendos, essa variável de interação mostrou que para cada aumento percentual dos direitos de voto do maior acionista último, a sensibilidade do investimento ao fluxo de caixa das firmas com pagamento de dividendos é reduzida. Isso mostra que uma maior concentração de votos reduz a dependência de fundos internos para a realização de investimento mesmo que a firma distribua dividendos.

Assim, interpretados os parâmetros obtidos pela estimação do modelo em (11) pelo método GMM para as firmas classificadas de acordo com o pagamento de dividendos, a análise segue para a interpretação dos resultados para as firmas agrupadas pelo tamanho.

Considerando as firmas agrupadas pelo tamanho, a variável fluxo de caixa $\left(F C / K_{t-1}\right)_{i, t}$ apresentou parâmetro significativo apenas para as firmas de tamanho pequeno, sendo não significativo mas positivo para as firmas de maior tamanho. Dessa forma, firmas de maior tamanho não dependeriam de seus fundos internos para a realização de seus investimentos. Já para firmas de menor tamanho, a variável fluxo de caixa obteve parâmetro negativo. Conforme analisado anteriormente pela tabela 8, firmas de menor tamanho apresentaram índices de rentabilidade menores do que as firmas de tamanho maior, o que indicaria que o parâmetro significativo da variável fluxo de caixa pode estar capturando a presença da restrição financeira nessas firmas. Além disso, de acordo com Goergen e Renneboog (2001), esse coeficiente negativo do fluxo de caixa pode estar detectando momentos de recessão na economia brasileira que pode ter afetado mais as firmas de menor tamanho do que as firmas grandes.

Com relação à variável dívida $\left(D / K_{t-1}\right)$, essa variável mostrou-se ser significativa e positiva tanto para as firmas maiores quanto para as firmas de menor tamanho. Contudo, firmas de maior tamanho apresentaram um maior parâmetro para esta variável quando comparadas as firmas pequenas. Esse parâmetro positivo e significativo para as firmas grandes pode estar indicando que essas firmas dependem mais do endividamento externo para a realização de investimentos do que as firmas pequenas, evidenciando assim, uma maior facilidade de acesso ao mercado externo possuídas pelas firmas de maior tamanho.

A variável pirâmide apresentou parâmetros significativos para ambos os grupos de firmas classificadas de acordo com o tamanho. Firmas com estrutura de propriedade piramidal e de menor tamanho reduzem sua taxa de investimento enquanto que firmas maiores elevam sua taxa de investimento quando estão inseridas em uma estrutura de propriedade piramidal. 
Isso pode estar indicando que pertencer a um esquema de pirâmide seria interessante quando a firma possuísse maior tamanho, visto que quando a firma fosse de tamanho menor, o mercado poderia associar a sua presença em uma estrutura de propriedade piramidal com uma maior existência de assimetrias de informações.

Considerando as naturezas de controle e propriedade, a variável controle por acordo entre acionistas apresentou parâmetro negativo e não significativo para as firmas consideradas de menor tamanho, no entanto, obteve parâmetro negativo e significativo para as firmas maiores. Isso significa que firmas consideradas grandes reduzem sua taxa de investimento quando o controle é dado por um acordo entre acionistas, implicando que um relacionamento próximo entre os grandes acionistas e gestores poderia contribuir para o aumento da assimetria de informação destes com os acionistas minoritários. Já a variável controle estatal e controle estrangeiro obtiveram parâmetros positivos e significativos apenas para as firmas de tamanho menor, indicando que aumentos no direito de voto do maior acionista último de natureza estatal e estrangeira contribuem para elevar a taxa de investimento das firmas consideradas pequenas.

Quando se considera o controle familiar, a variável controle familiar obteve parâmetros significativos, mas com sinais opostos entre as firmas de maior e menor tamanho. Para firmas consideradas pequenas, o controle familiar reduz a taxa de investimento, enquanto que firmas maiores elevam sua taxa de investimento quando o controle é familiar. Considerando que em muitas firmas controladas por famílias os gestores são os próprios membros da família, o controle familiar pode contribuir para aumentar informações assimétricas entre grandes acionistas e acionistas minoritários, aumentando os custos de agência e consequentemente, reduzindo o potencial de investimento das firmas de menor tamanho. No entanto, quando as firmas são de tamanho maior, estas geralmente já são conhecidas e bem sucedidas no mercado, obtendo financiamento externo com mais facilidade mesmo que seus gestores sejam membros da família controladora.

A variável $C D$, que identifica a presença do maior acionista último no conselho de administração e na direção da firma foi positiva e significativa tanto para as firmas consideradas grandes quanto para as firmas consideradas pequenas. Isso mostra que indiferentemente do tamanho da firma, a presença do maior acionista último no conselho e na direção da firma contribui para elevar a taxa de investimento. Portanto, essa sobreposição de funções do maior acionista último pode estar ajudando a reduzir problemas de assimetria de informação entre gestores e acionistas, o que significa que mesmo que o conselho não seja totalmente independente, este está cumprindo com suas funções. 
A variável de interação entre o fluxo de caixa e o nível de governança corporativa $\left(F C / K_{t-1}\right)_{i, t} *$ nivelgc apresentou parâmetros significativos tanto para as firmas de maior tamanho quanto para as firmas pequenas. Firmas de tamanho pequeno elevam sua sensibilidade do investimento ao fluxo de caixa quando estão inseridas em um dos níveis diferenciados de governança corporativa, o que mostra que a adesão a um dos níveis diferenciados contribuem para aumentar a dependência de fundos internos para a realização de investimento para esse grupo de firmas. Já firmas de maior tamanho diminuem sua dependência em relação aos fundos internos dado que o parâmetro obtido pela variável de interação foi negativo.

Relacionando o fluxo de caixa com os direitos de fluxo de caixa do maior acionista último, observa-se que a variável $\left(F C / K_{t-1}\right)_{i, t} * \operatorname{dirfc}$ obteve sinal positivo e significativo para as firmas de menor tamanho. Isso indica que o aumento nos direitos de fluxo de caixa do maior acionista último para essas firmas está associado a uma maior dependência de recursos internos para investir. Dessa forma, a maior participação acionária do maior acionista último em firmas pequenas pode estar contribuindo para aumentar assimetria de informação entre grandes e pequenos acionistas. Para as firmas de maior tamanho, essa variável de interação apresentou parâmetro negativo, indicando que a dependência por fundos internos é reduzida com uma maior participação do acionista último nas decisões da firma. Já a variável de interação entre o fluxo de caixa e os direitos de voto do maior acionista último, $\left(F C / K_{t-1}\right)_{i, t}$ * dirvoto, foi positiva e significativa tanto para as firmas de tamanho menor quanto para as firmas consideradas grandes. Isso indica que independentemente do tamanho das firmas, a maior concentração de votos por parte do maior acionista último contribui para elevar a sensibilidade do investimento ao fluxo de caixa, refletindo em uma maior dependência de fundos internos para a realização de investimentos.

Em síntese, a estimação para os grupos de firmas classificadas de acordo com o índice KZ, pagamento de dividendos e tamanho da firma possibilitou analisar o comportamento dos mecanismos de governança corporativa nas decisões de investimento das firmas. Assim, pôde-se observar a importância que a estrutura de propriedade e controle, a participação do maior acionista último e seus percentuais de direito de voto e de fluxo de caixa possuem sobre a decisão de investimentos das firmas. No próximo capítulo será realizada as conclusões dos resultados obtidos neste estudo. 


\section{Conclusão}

A principal discussão sobre as decisões de investimento tem se concentrado no papel da restrição financeira e como testá-la no comportamento do investimento corporativo. Diversos critérios têm sido propostos pela literatura no intuito de classificar as firmas em grupos que possibilitem diferenciá-las como restrita financeiramente, considerando aspectos comuns entre as mesmas. Dentre os critérios de classificação mais empregados na literatura estão: tamanho e idade das firmas; taxa de pagamento de dividendos; intensidade de capital; commercial papers; bond rating; idade e dispersão de propriedade, entre outros. No entanto, Povel e Raith (2001) e Cleary, Povel e Raith (2007) mostraram que grande parte das divergências na literatura do investimento está relacionada ao modo de se interpretar e definir o que seria restrição financeira e o modo de discriminar entre as firmas que sofreriam ou não com restrições ao financiamento. Por exemplo, Kaplan e Zingales (1997) consideraram uma firma restrita financeiramente se os custos ou a disponibilidade de fundos externos a impedissem de realizar novos empreendimentos que teria escolhido se recursos internos estivessem disponíveis. Já para Lamont, Polk Saá-Requejo (2001), restrição financeira foi interpretada como os atritos que impedem a firma de realizar todos os investimentos por ela desejados. Essa incapacidade de conseguir investimento poderia estar relacionada com a falta de crédito, com a dependência de empréstimos bancários ou com a falta de liquidez.

Embora existam muitos estudos sobre a decisão de investimentos na presença da restrição financeira, a discussão em torno deste tema continua intensa. Recentes estudos têm incorporado a estrutura de governança corporativa para explicar o comportamento do investimento das firmas. Estudos como Hadlock (1998), Ginglinger e Saddour (2007), Wei e Zhang (2008) Harford et al. (2008) e, Chen, Huang e Chen (2009) analisaram como mecanismos de governança corporativa estão relacionados com a forma com que credores e acionistas investem na firma, ou seja, como estes mecanismos poderiam reduzir seu grau de restrição financeira e intensificar seus investimentos.

Considerando este enfoque da literatura sobre a decisão de investimento, este estudo procurou contribuir para a literatura, destacando que para a literatura brasileira não constatouse estudos que relacionam decisão de investimento e governança corporativa. Nesse sentido, este estudo teve por objetivo analisar como mecanismos de governança corporativa juntamente com a presença da restrição financeira influenciam nas decisões de investimentos, tomando como base uma amostra de 500 firmas brasileiras de capital aberto no período de 1997 a 2007. Para alcançar este objetivo, primeiramente foi estimado um modelo 
probabilístico logit por efeito aleatório. E em um momento posterior, o comportamento do investimento da firma foi analisado por meio de uma versão modificada do modelo acelerador estimado pelo método dos momentos generalizados (GMM), o qual procurou explicar o investimento considerando características de governança corporativa das firmas.

A variável dependente do modelo logit foi criada com base no índice KZ, desenvolvido por Lamont, Polk e Saá-Requejo (2001). Este índice considera características financeiras da firma para ordená-la conforme o grau de restrição ao financiamento. Dessa forma, firmas que apresentaram índice $\mathrm{KZ}$ superiores a mediana foram identificadas como restritas financeiramente e, firmas com índice $\mathrm{KZ}$ inferiores a mediana foram identificadas como não restritas financeiramente. Essa classificação permitiu a elaboração da variável $K Z$ que exibe valor igual a 1 se a firma for considerada, de acordo com o índice KZ, restrita financeiramente e zero, caso contrário. Os principais resultados obtidos por esta estimação indicaram que a probabilidade de restrição financeira é afetada positivamente quando o maior acionista último de natureza familiar ou estrangeira é o acionista controlador da firma. Além disso, apesar de estudos como o de Bianco e Casavola (1999) apresentar resultados que indiquem que a propriedade piramidal possa aliviar a restrição financeira devido à transferência de recursos dentro da pirâmide, os resultados do modelo logit indicaram que se existe transferência de recursos entre as firmas pertencentes a pirâmide, esta transferência pode estar ocorrendo para maximizar o retorno do acionista controlador da estrutura piramidal.

Para se investigar como mecanismos de governança corporativa e a presença da restrição financeira repercutem sobre o comportamento do investimento das firmas, estimouse uma versão do modelo acelerador de investimento. Este modelo foi estimado pelo método dos momentos generalizados (GMM) para considerar o seu aspecto dinâmico e corrigir o problema da endogeneidade causado pela inclusão da variável dependente defasada como variável regressora.

Além das distintas formas de classificação da amostra para identificar a presença de restrição financeira, utilizou-se também da análise da sensibilidade do investimento ao fluxo de caixa. Inicialmente, esta análise considera que uma firma possa ser considerada restrita financeiramente se um aumento inesperado em seus fundos internos acarretar em uma elevação de sua taxa de investimento; enquanto que as firmas seriam consideradas não restritas financeiramente, caso não dependessem de seus fundos internos para a realização de seus investimentos. Assim, quanto maior fosse a sensibilidade do investimento ao fluxo de caixa, maior seria o grau de restrição financeira da firma. Diversas críticas surgiram 
contestando a validade da sensibilidade do investimento ao fluxo de caixa como único critério para se identificar a presença da restrição financeira. A principal crítica foi dada por Kaplan e Zingales (1997) que atentaram para o fato de que a significância positiva da variável fluxo de caixa também poderia estar sinalizando potencial para rentabilidade futura. Outras críticas, tal como a de Povel e Raith (2001), ressaltaram que a forma com que as firmas são agrupadas também poderia comprometer a validade da análise da sensibilidade do investimento ao fluxo de caixa, visto que a presença de heterogeneidade entre as firmas poderia repercutir em resultados ambíguos quanto a identificação da presença da restrição financeira. Dessa forma, estudos subsequentes passaram a combinar informações quantitativas e qualitativas, a fim de se identificar aspectos que confirmem que a variável de liquidez indica a presença de restrição financeira sobre as decisões de investimento da firma.

Neste sentido, para a estimação do modelo de investimento considerou-se três tipos de agrupamentos: a classificação entre firmas restritas e não restritas financeiramente de acordo com o índice KZ, o tamanho das firmas e o pagamento de dividendos. Os resultados estimados mostraram que firmas com baixo índice $\mathrm{KZ}$, firmas consideradas de menor tamanho e firmas que não distribuem dividendos possuem uma sensibilidade negativa do investimento ao fluxo de caixa, evidenciando que estas firmas dependem de seus fundos internos para a realização de investimentos, mas que, entretanto, a elevação do fluxo de caixa reduz a taxa de investimento das firmas. Com isso, considerando seus baixos indicadores de rentabilidade em relação aos demais grupos de firmas, pôde-se inferir que a variável fluxo de caixa não estaria sujeita a crítica de que estaria sinalizando o potencial de rentabilidade futura, indicando, dessa forma, a presença de restrição financeira. Além disso, de acordo com Baghat et al. (2005), esse parâmetro negativo para o fluxo de caixa poderia estar relacionado com o fraco desempenho operacional destas firmas, já que firmas com dificuldades financeiras e com perdas operacionais tenderiam a continuar suas atividades e seus investimentos para tentar obter um melhor desempenho em momentos posteriores.

Em relação à estrutura de propriedade e controle, evidências mostram que diferentes naturezas do acionista controlador refletem em influências distintas sobre a decisão de investimento das firmas. Os resultados sugerem que firmas controladas pelo Estado apenas sofrem interferência de seu acionista controlador quando enfrentam dificuldades financeiras e estão em desenvolvimento. Essa influência positiva do acionista controlador nas decisões de investimento de firmas estatais poderia estar indicando que o Estado se comprometeria a ajudar no fortalecimento e no crescimento de suas firmas a fim de obter um maior retorno futuro. Além disso, as estimações indicaram que acionistas estrangeiros também interfeririam 
positivamente nas decisões de investimento das firmas que detém controle quando estas apresentassem dificuldades financeiras. Já a influência do acionista controlador nas decisões de investimento de firmas familiares dependeria do tamanho da firma e de sua situação financeira. Quando as firmas possuíssem um maior tamanho ou estivesse em dificuldade financeira, o acionista controlador interferiria positivamente nas decisões de investimento das firmas. Caso a firma fosse de menor tamanho e em melhor situação financeira, a presença do acionista controlador de natureza familiar causaria um impacto negativo sobre a taxa de investimento dessas firmas.

Com relação à estrutura de propriedade piramidal, os resultados mostraram que firmas com esse tipo de estrutura reduzem sua taxa de investimento quando estão em dificuldades financeiras. Porém, essas firmas elevarão sua taxa de investimento quando forem consideradas não restritas pelo índice $\mathrm{KZ}$ ou forem de maior tamanho. Isso poderia estar evidenciando que não basta a firma estar inserida em um esquema de pirâmide para haver transferência de recursos que beneficiem a realização de novos investimentos. Provavelmente, essa transferência de recursos esteja associada ao tamanho das firmas e ao seu grau de endividamento em relação com o patrimônio líquido, já que a possibilidade de falência e do não pagamento do empréstimo concedido poderia comprometer as demais firmas inseridas na estrutura piramidal.

O aumento na taxa de investimento das firmas que aderiram a um dos níveis diferenciados de governança corporativa ou ao Novo Mercado está condicionado a sua situação financeira. Para firmas em dificuldades financeiras, inserir-se em um dos segmentos diferenciados de governança corporativa eleva a dependência por recursos internos para a realização de investimentos, evidenciando que apenas a adesão a um dos níveis diferenciados ou ao Novo Mercado não é garantia de aumento nos investimentos. Este resultado pode estar refletindo as dificuldades que tais firmas enfrentariam para se manter nos níveis de governança corporativa, dado os altos custos para se cumprir as exigências feitas pelo órgão regulador. Todavia, para as firmas em melhor situação financeira, o resultado foi condizente com o esperado, ou seja, firmas que adotam políticas de boa governança corporativa, mensuradas pelos segmentos de listagem de governança corporativa da BM\&FBOVESPA, reduzem sua dependência por fundos internos e elevam suas taxas de investimento.

A maior participação acionária do maior acionista último representada pelo aumento nos direitos de fluxo de caixa deste acionista contribui para reduzir a sensibilidade do investimento ao fluxo de caixa das firmas. Entretanto, quando a firma for considerada de menor tamanho, o aumento nos direitos de fluxo de caixa do maior acionista último contribui 
para elevar a dependência em relação aos fundos internos para a realização de investimento, agravando sua restrição financeira. Esse fato sugere que a maior participação acionária do maior acionista último em firmas pequenas contribui para aumentar a assimetria de informação entre grandes acionistas e acionistas minoritários, e consequentemente, elevar os custos de agência.

Por outro lado, uma elevação nos direitos de voto dos maiores acionistas últimos, eleva a sensibilidade do investimento ao fluxo de caixa, evidenciando que uma maior concentração de votos em posse do maior acionista último contribui para aumentar a dependência dos fundos internos. Contudo, quando a firma distribui dividendos, a sensibilidade do investimento ao fluxo de caixa é reduzida mesmo com o aumento na concentração de direitos de voto por parte do maior acionista último, indicando que o pagamento de dividendos pode cooperar com a redução de assimetria de informações em firmas com grande concentração de propriedade.

Em suma, pode-se concluir que diferentes estruturas de propriedade e controle possuem impactos distintos sobre as decisões de investimento, e que apenas ser integrante de uma estrutura de propriedade piramidal não é suficiente para haver transferências de recursos que elevem a taxa de investimento das firmas. Além disso, a adesão a um dos níveis diferenciados de governança corporativa da BM\&FBOVESPA ou ao Novo Mercado não é garantia de aumento nas taxas de investimento; este aumento dependeria da situação financeira da firma. A maior participação acionária do maior acionista último pode contribuir para reduzir a assimetria de informação, exceto quando a firma for de menor tamanho. Já o aumento nos direitos de voto do maior acionista último apenas reduz a dependência por fundos internos quando firma distribui dividendos, o que pode estar evidenciando que este aumento nos direitos de voto do maior acionista último apenas é aceitável pelos demais acionistas quando a firma distribui os dividendos, caso contrário, os acionistas minoritários vêem este aumento como um potencial para a expropriação de seus direitos, principalmente se o maior acionista último participar ativamente do conselho de administração e da direção da firma.

Por fim, considerando os resultados apresentados acima, esse estudo ressalta a importância dos mecanismos de governança corporativa sobre as decisões de investimento. Esta pesquisa também contribui para a literatura, visto que estudos que analisam a relação dos mecanismos de governança corporativa e restrição financeira nas decisões de investimento são escassos na literatura. 


\section{REFERÊNCIAS}

ALDRIGHI, D. M; MAZZER, R. N. Evidências sobre as Estrutura de Propriedade de Capital de Voto das Empresas de Capital Aberto no Brasil, Revista Brasileira de Economia, 61(2), 129-152, 2007.

ALLAYANIS, G.; MOZUMDAR, A. The Impact of negative flow and influent observations on investment-cash flow sensitivity estimates. Journal of Banking and Finance, 28, 901-930, 2004.

ALMEIDA, H.; CAMPELLO, M. Financial Constraints and Investment-Cash Flow Sensitivities: New Research Directions. Working paper, New York University and University of Illinois, 2002.

ALMEIDA, H.; CAMPELLO, M.; WEISBACH, M. The Cash flow Sensitivity of Cash. The Journal of Finance, v. 59 (4), 1777-1804, 2004.

ANDERSON, T. W.; HSIAO, C. Estimation of dynamic models with error components. Journal of the American Statistical Association, v. 76, 598-606, 1981.

ANDRESS, C. Family ownership, Financing constraints and Investment Decisions, Working Paper, 2008.

ANG, J. S.; COLE, R. A.; WUH LIN, J. Agency costs and ownership structure, Journal of Finance 55, 81-106, 2000

ARACHYA, V. V.; ALMEIDA, H., CAMPELLO, M., Is cash negative debt? A hedging perspective on corporate financial policies, Journal of Financial Intermediation, 16, 515-554, 2007.

ARELLANO, M. A note on the Anderson-Hsiao estimator for panel data. Economics Letters, v. 31, 337-341, 1989.

ARELLANO, M.; BOND, S. Some tests of specification for panel data: Monte Carlo evidence and an application to employment equations. Review of Economic Studies, v. 58 (2), 277-297, 1991.

ATTING, N.; FISCHER, K.; GADHOUM, Y., On the Determinants of Pyramidal Ownership: Evidence on Dilution of Minority Interests, 2002. 
BALTAGI, B. H. Econometrics analysis of panel data, 3a.ed,. John Wiley \& Sons, England, 2005.

BEBCHUCK, L.; COHEN, A.; FERREL, A. What matters in Corporate Governance?, The Review of Financial Studies, 22(2), 783-827, 2009

BERLE, A. A.; MEANS, G. C. The modern corporation and private property, Macmillan, New York, 1932.

BHAGAT, S.; MOYEN, N. T; SUH, I. Investment and Internal Funds of Distressed Firms. Journal of Corporate Finance, 11, 449-472, 2005.

BIANCO, M.; CASAVOLA, P. Italian Corporate Governance: Effects on Financial Structure and Firm Performance, European Economic Review 43: 1057-1069, 1999.

BLACK, B. S.; CARVALHO, A. G.; GORGA, E. Corporate governance in Brazil, Emerging Markets Review, v.11, 21-38, 2010.

BM\&FBOVESPA (2006). Regulamento Nível 1. Disponível em $<$ http://www.BM\&FBovespa.com.br/pdf/RegulamentoNivel1.pdf>. Acesso em 08 de abril de 2010.

BM\&FBOVESPA (2006). Regulamento Nível 2. Dissponível em $<$ http://www.BM\&FBovespa.com.br/pdf/RegulamentoNivel2.pdf> Acesso em 08 de abril de 2010.

BM\&FBOVESPA (2006). Regulamento Novo Mercado. Disponível em $<$ http://www.BM\&FBovespa.com.br/pdf/RegulamentoNMercado.pdf>. Acesso em 08 de abril de 2010.

BM\&FBOVESPA (2009). Regulamento Bovespa Mais. Disponível em http://www.bmfbovespa.com.br/pt-br/a-bmfbovespa/download/BOVESPAMais_folder.pdf>. Acesso em 08 de abril de 2010.

BOND, S.; MEGHIR, C. Dynamic Investment Models and Firm's Financial Policy. Review of Economics Studies, v. 61, 197-222, 1994.

BOND, S.; REENEN, V. J. Microeconometric models of investment and employment. In: HECKMAN, J., LEAMER, E. Handbook of Econometrics, 2003. 
BOOZ\&COMPANY; IBGC (2009) Panorama da Governança Corporativa no Brasil.

Disponível em:

<http://www.ibgc.org.br/Download.aspx?Ref=PesquisaConhecimento\&CodPesquisa=20>.

Acesso em maio de 2010

BORGES, L.F.X; SERRAO, C.F.B. Aspectos de Governanca Corporativa Moderna no Brasil, Revista do BNDES, v.12 (24), 111-148, 2005.

CAMERON, A. C.; TRIVEDI, P. K Microeconometrics using Stata, Stata Press: Texas, United States, 2010.

CAMERON, A. C.; TRIVEDI, P. K Microeconometrics: methods and applications, Cambrigde University Press: New York, United States, 2005.

CAPERTER, R. E.; RONDI, L. Italian corporate governance, investment and finance, Journal Empirica, 27: 365-388, 2000.

CARPENTER, S. M.; GUARIGLIA, A. Cash Flow, Investment, and Investment Opportunities: new tests using UK panel data. Journal of Banking and Finance, v. 32, 18941906, 2008.

CARVALHO, A. G. Governança Corporativa no Brasil em perspectiva. Revista de Administração, v.37, 19-32, 2002.

CHAE, J.; KIM, S. E LEE, E. J., How corporate governance affects payout policy under agency problems and external financial constraints, Journal of Banking and Finance, 33, 2093-2101, 2009.

CHEN, Y., CHUANG, W., Aligment or entrenchment? Corporate governance and cash holdings in growing firms, Journal of Business Research, 62, 1200-1206, 2009

CHEN, Y.; HUANG, Y.; CHEN, C. Financing Constraints, Ownership Control, and CrossBorder M\&As: Evidence from Nine East Asian Economies. Corporate Governance: an International Review, v. 17(6): 665-680, 2009.

CLAESSENS, S.; DJANKOV, S.; LANG, L. H.P. The separation of ownership and control in East Asian Corporation. Journal of Financial Economics, 58: 81-112, 2000. 
CLAESSENS, S.; DJANKOV, S.; Lang, L. H.P. Disentangling the Incentive and Entrenchement Effects of Large Shareholders. Journal of Finance, 57: 2741-2771, 2002.

CLEARY, S. The Relationship Between Firm Investment and Financial Status. The Journal of Finance, v. 54 (2), 673-692, 1999.

CLEARY, S. International Corporate Investment and the Relationships between Financial Constraints Measures. Journal of Banking and Finance, 30, 1559-1580, 2006.

CLEARY, S.; POVEL, P.; RAITH, M. The U-Shaped Investment Curve: Theory and Evidence. Journal of Financial and Quantitative Analysis, v. 42 (1), 2007.

CRESPI, F.; SCELLATO, G. Ownership structure, financial constraints and investment decisions: Evidence from a panel of Italian firm, Working Paper, 2007.

CVM (2002). Recomendações sobre Governança Corporativa da CVM. Disponível em $<$ http://www.cvm.gov.br/port/public/publ/cartilha/cartilha.doc>. Acesso em 10 de abril de 2010.

DENIS, D. J., SIBILOV, V., Financial Constraints, Investment and the Value of Cash Holdings, The Review of Financial Studies, 23, 247-269, 2010

DEVEREUX, M.; SCHIANTARELLI, F. Investment, Financial Factors, and Cash Flow: Evidence from U.K Panel Data. In HUBBARD, R.G. Asymmetric Information, Corporate Finance, and Investment. Chicago: Chicago University Press, 1990.

DITMAR, A.; MARTH-SMITH, J., E SERVAES, H., International Corporate Governance and Corporate Cash Holding. Journal of Financing and Quantitative Analysis 38, 111-133, 2003.

FACCIO, M.; LANG, L. H. P. The ultimate ownership of Western European Corporation, Journal of Financial Economics, 65: 365-395, 2002.

FAMA, E.; Agency Problems and the Theory of the Firm, The Journal of Political Economy, 88(2), 288-307, 1980.

FAMA, E.; JENSEN, M. Separation of ownership and control. Journal of Law and Economics, v.26, 301-327, 1983. 
FAZZARI, S. M; HUBBARD, R. G.; PETERSEN, B. C. Financing Constraints and Corporate Investment. Brookings Papers on Economic Activity, v. 1988 (1), 141-195, 1988.

FAZZARI, S. M; HUBBARD, R. G.; PETERSEN, B. C. Financing Constraints and Corporate Investment: Response to Kaplan and Zingales. National Bureau of Economic Research, Working Paper Series n. 5462, 1996.

FRIEDMAN, M. The methodology of positive economics, in Essay in Positive Economics, 343, Chicago: University of Chicago, 1953.

GILLAN, S.L.; STARKS, L.T. A survey of shareholder activism: motivation and empirical evidence. Contemporary Financial Digest, 2(3), 10-34, 1998.

GILCHRIST, S.; C. P. HIMMELBERG. Evidence on the role of cash flow for investment. Journal of Monetary Economics, v. 36, 541-572, 1995.

GINGLINGER, E.; SADDOUR, K. Cash constraint, corporate governance and financial constraints. Working Paper, 2008.

GOMES, J. F. Financing Investment. The American Economic Review, v. 91 (5), 1263-1285, 2001.

GOERGEN,M.; RENNEBOOG, L. Investment policy, internal financing and ownership concentration in the UK, Journal of Corporate Finance, v. 7 (3), 257-284, 2001.

GUGLER, K. Corporate governance and investment. Journal of the Economics of Business, 10: 261-289, 2003.

HADLOCK, C. J. Ownership, liquidity and investment, The Rand Journal of Economics, 29(3), 487-508, 1998.

HARFORD, J.; MANSI, S. A.; MAXWELL, W. F. Corporate Governance and Firm Cash Holding in The US. Journal of Financial Economic, 87: 535-555, 2008.

HERMALIN, B.; WEISBACH, M. Boards of Directors as an Endogenously Determined Institution: A Survey of the Economic Literature. FRBNY Economic Policy Review, 7-26, 2003.

HOLM, C.; SCHOLER, F., Reduction of asymmetric information through corporate governance mechanisms: the importance of ownership dispersion and exposure toward the 
international capital markets, Corporate Governance: An International Review, 18(1), 32-47, 2010 .

HOSHI, T.; KASHYAP, A. K.; SCHARFSTEIN, D. Corporate structure, liquidity and investment: evidence from japanese industrial groups. Quarterly Journal of Economics, v. 101, 33-60, 1991.

HSIAO, C.; TAHMISCIOGLU, A. K. A Panel Analysis of Liquidity Constraints and Firm Investment. Journal of the American Statistical Association, v. 92 (438), 455-465, 1997.

IBGC (2009). Código das Melhores Práticas de Governança Corporativa. Disponível em < www.ibgc.org.br/Download.aspx?Ref=Codigos\&CodCodigo=47 >. Acesso em 06 de abril de 2010.

JENSEN, M. Agency costs of free cash flow, corporate finance and takeovers. American Economic Review 76: 323-329, 1986.

JENSEN, M; MECKLING, W. H. Theory of the Firm: managerial Behavior, Agency Costs and Ownership Structure. Journal of Financial Economics, 1976, v. 3 (4), 305-360, 1976.

JORGENSON, D. W. Capital Theory and Investment Behavior. The American Economic Review, v. 53 (2), 247-259, 1963.

KALATZIS, A.E.G.; AZZONI, C.; ACHCAR, J.A. Financial constraints and investment decisions: evidence from a highly unstable emerging economy. Applied Economics, 40, 14251434, 2008.

KALATZIS, A.E.G.; AZZONI, C.; ACHCAR, J.A. Investment decisions in trouble times: a Bayesian approach applied to Brazilian firms, International Journal of Production Economics, 595-606, 2009.

KAPLAN, S. N.; ZINGALES, L. Do Investment-Cash Flow Sensitivities Provide Useful Measures of Financing Constraints? The Quartely Journal of Economics, v. 112, 169-215, 1997.

KNYAZEVA, A.; KNYAZEVA, D.; STIGLITZ., J., Ownership changes and access to external financing, Journal of Banking and Finance, 33, 1804-1816, 2009. 
LAMONT, O.; POLK, C.; SAÁ-REQUEJO, J. Financial Constraints and Stock Returns. The Review of Financial Studies, v. 14 (2), 529-554, 2001.

LA PORTA, R. et al. Legal determinants of external finance. Journal of Finance, v. 52, 11311150, 1997.

LA PORTA, R.; LOPEZ-DE-SILANES, F.; SHLEIFER, A. Corporate Ownership around the World. The Journal of Finance, 54, 471-517, 1999.

LA PORTA, R., F. LOPEZ-DE-SILANES, ET AL. Investor protection and corporate governance." Journal of Financial Economics 58(1-2): 3-27, 2000.

LEAL, R. P. C.; CARVALHAL-DA-SILVA, A.L. Controle Compartilhado e o Valor das Empresas Brasileiras. Disponível em <http://www.anpad.org.br/rac-e>, 2008

LINCK, J. S.; NETTER, J. M.; YANG, T. Determinants of board structure, Journal of Financial Economics, 87, 308-328, 2008.

MALLIN, C. A., Corporate Governance. New York: Oxford University Press, 2004

MCKINSEY \& COMPANY; KORN/ FERRY INTERNATIONAL (2001). Panorama de governança corporativa no Brasil. Disponível em <http://www.egci.org/codes/documents/kf_mcf_governan.pdf $>$. Acesso em 09 de abril de 2010.

MODIGLIANI, F.; MILLER, M. The Cost of Capital, Corporation Finance and the Theory of Investment. American Economic Review, v. 48 (3), 261-297, 1958.

MOREIRA, M. M.; PUGA, F. P. Como a Indústria Financia o seu Crescimento - Uma Análise do Brasil Pós-Real. Revista de Economia Contemporânea, v. 5, 35-67, 2001.

MOYEN, N. Investment-Cash Flow Sensitivities: Constrained versus Unconstrained Firms. The Journal of Finance, v. 59 (5), 2061-2092, 2004.

MYERS, S.; MAJLUF, N. Corporate financing and investment decision when firms have information that investors do not have. Journal of Financial Economics, v.13, 187-221, 1984. 
POVEL, P.; RAITH, M. Optimal Investment Under Financial Constraints: The Roles of Internal Funds and Asymmetric Information. Working paper, University of Chicago e University of Minnesota, 2001.

RABELO, F.; SILVEIRA, J. M., Estrutura de Governança e Governança Corporativa: avançando na direção da integração entre as dimensões competitivas e financeiras. Texto para discussão: Instituto de Economia - UNICAMP, n. 77

RAHEJA, C., Determinants of board size and composition: a theory of corporate boards, Journal of Financial and Quantitative Analysis, 40, 283-306, 2005

ROE, M. J. The Institutions of Corporate Governance, Handbook of New Institutional Economics, 371-399, 2005.

SCHALLER, H. Asymmetric information, liquidity constraints, and Canadian investment. Canadian Journal of Economics, v. 26 (3-4), 552-574, 1993.

SHLEIFER, A.; VISHNY, R. W. A survey of corporate governance. Journal of Finance, v.52, 737-783, 1997.

SETIA-ATMAJA, L. Y. Governance Mechanisms and Firm Value: The impact of Ownership Concentration and Dividends. Corporate Governance: An International Review, 17: 694-709, 2009.

SILVEIRA, A. D. M. Governança corporativa, Desempenho e Valor da Empresa no Brasil. Dissertação de Mestrado. São Paulo: Faculdade de Economia, Administração e Contabilidade da Universidade de São Paulo, 2002

SINGH, A. Competition, Corporate Governance and Selection in Emerging Markets, The Economic Journal, 113, v. 491, F443-F464, 2002

TERRA, C. M. Credit Constraints in Brazilian Firms: Evidence from Panel Data. Revista Brasileira de Economia, v. 57 (2), 444-464, 2003.

TIROLE, J. The theory of Corporate Governance. Princeton University Press, 2006

TONG, Z. Firm diversification and the value of corporate cash holding, Journal of Corporate Finance, Disponível on line <10.1016/j.jcorpfin.2009.05.001>, 2009 
WEI, J. K.C.; ZHANG, Y. Ownership structure, cash flow and capital investment: Evidence from East Asian economies before the financial crisis. Journal of Corporate Finance, 14: 118-132, 2008.

WOLFENSON, D. A theory of pyramidal ownership, Harvard University, 1998.

WOOLDRIDGE, J. M., Introdução à Econometria: uma abordagem moderna, Pioneira Thomson Learning, 2006. 


\section{Apêndice A}

Quadro A.1: Definição das variáveis de Governança Corporativa

\begin{tabular}{|c|c|}
\hline Determinantes de GC (código) & Definição \\
\hline Maior Acionista Último (LUS) & $\begin{array}{l}\text { É o acionista que detém maior porcentagem de } \\
\text { direito de voto por meio de uma estrutura de } \\
\text { propriedade direta ou indireta. }\end{array}$ \\
\hline Identidade do LUS & $\begin{array}{l}\text { A natureza do maior acionista último permite } \\
\text { classificá-lo em: familiar, estatal, estrangeiro, } \\
\text { institucional, acordo entre acionistas, e outros. }\end{array}$ \\
\hline Acionista controlador & $\begin{array}{l}\text { É o acionista que detém mais do que } 50 \% \text { dos } \\
\text { direitos de voto da firma. Nem sempre o maior } \\
\text { acionista último será o acionista controlador da } \\
\text { firma. }\end{array}$ \\
\hline Controlador (controle) & $\begin{array}{l}\text { Variável binária que assume valor igual a } 1 \text { caso } \\
\text { o maior acionista último seja também o acionista } \\
\text { controlador da firma, e, assume valor zero, caso } \\
\text { contrário. }\end{array}$ \\
\hline Acordo entre acionistas & $\begin{array}{l}\text { Variável binária que assume valor } 1 \text { se a natureza } \\
\text { do maior acionista último é acordo entre } \\
\text { acionistas (i.e. o LUS é uma reunião de acionistas } \\
\text { ligados por um contrato legal no qual todos estes } \\
\text { acionistas possuem direitos iguais sobre as } \\
\text { decisões da firma), e assume valor zero, caso } \\
\text { contrário. }\end{array}$ \\
\hline Familiar & $\begin{array}{l}\text { Variável binária que assume valor } 1 \text { se a natureza } \\
\text { do maior acionista último é familiar, e assume } \\
\text { valor zero, caso contrário. }\end{array}$ \\
\hline Estatal & $\begin{array}{l}\text { Variável binária que assume valor } 1 \text { se o maior } \\
\text { acionista último for o Estado, e assume valor } \\
\text { zero, caso contrário. }\end{array}$ \\
\hline Estrangeira & $\begin{array}{l}\text { Variável binária que assume valor } 1 \text { se a natureza } \\
\text { do maior acionista último for estrangeira e } \\
\text { assume valor zero, caso contrário. }\end{array}$ \\
\hline Institucional & $\begin{array}{l}\text { Variável binária que assume valor } 1 \text { se a natureza } \\
\text { do maior acionista último for fundos de pensão } \\
\text { e/ou fundos de investimento, e assume valor zero, } \\
\text { caso contrário. }\end{array}$ \\
\hline Outros & $\begin{array}{l}\text { Variável binária que assume valor } 1 \text { se a natureza } \\
\text { do maior acionista último for múltiplo, S.As ou } \\
\text { limitada, e assume valor zero, caso contrário. }\end{array}$ \\
\hline
\end{tabular}


Quadro A.1 (continuação): Definição das variáveis de Governança Corporativa

\begin{tabular}{|c|c|}
\hline $\begin{array}{l}\text { Determinantes de GC } \\
\text { (código) }\end{array}$ & Definição \\
\hline Controle_X & $\begin{array}{l}\text { Variável binária que assume valor } 1 \text { se o maior } \\
\text { acionista último é o acionista controlador da } \\
\text { firma com natureza } X \text {, sendo } X=\{\text { Acordo entre } \\
\text { Acionistas; Estatal; Estrangeiro; Familiar; } \\
\text { Institucional; Outros }\}\end{array}$ \\
\hline Pirâmide & $\begin{array}{l}\text { Variável binária que assume valor } 1 \text { se a firma } \\
\text { pertence a uma estrutura de propriedade } \\
\text { piramidal, e assume valor zero, caso contrário. }\end{array}$ \\
\hline Conselho de Administração (conselho) & $\begin{array}{l}\text { Variável binária que assume valor } 1 \text { se o maior } \\
\text { acionista último é membro do conselho de } \\
\text { administração da firma, e assume valor zero, caso } \\
\text { contrário. }\end{array}$ \\
\hline Diretor & $\begin{array}{l}\text { Variável binária que assume valor } 1 \text { se o maior } \\
\text { acionista último atua como diretor da firma, e } \\
\text { assume valor zero, caso contrário. }\end{array}$ \\
\hline $\begin{array}{l}\text { Presença do LUS no conselho e como diretor } \\
\text { (CD) }\end{array}$ & $\begin{array}{l}\text { Variável binária que assume valor } 1 \text { se o maior } \\
\text { acionista último atuar como diretor e ser membro } \\
\text { do conselho de administração, e assume valor } \\
\text { zero, caso contrário. Inseriu-se essa variável para } \\
\text { analisar a sobreposição de funções do LUS dentro } \\
\text { da firma. }\end{array}$ \\
\hline Direito de Fluxo de Caixa (dirfc) & $\begin{array}{l}\text { Percentual de direito de fluxo de caixa (direito de } \\
\text { propriedade) do maior acionista último. }\end{array}$ \\
\hline Direito de Voto (dirvoto) & $\begin{array}{l}\text { Percentual de direito a voto do maior acionista } \\
\text { último. }\end{array}$ \\
\hline Desvio & $\begin{array}{l}\text { É a diferença entre o percentual de direito a voto } \\
\text { e de fluxo de caixa do maior acionista último. }\end{array}$ \\
\hline $\begin{array}{c}\text { Adesão aos Níveis de Governança Corporativa da } \\
\text { BM\&FBOVESPA (nivelgc) }\end{array}$ & $\begin{array}{l}\text { Variável binária que assume valor } 1 \text { se a firma } \\
\text { aderiu a um dos níveis de governança corporativa } \\
\text { da BM\&FBOVESPA. (Nível } 1 \text {, Nível } 2 \text { ou Novo } \\
\text { Mercado), e assume valor zero caso contrário. }\end{array}$ \\
\hline
\end{tabular}


Quadro A.2: Definição das variáveis financeiras

\begin{tabular}{|c|l|}
\hline Abreviatura & \\
\hline K & Estoque de Capital, medido pelo Imobilizãado \\
\hline I & Taxa de investimento da firma, medida por $\left(K_{t}-K_{t-1}\right) / K_{t-1}$ \\
\hline FC & Fluxo de Caixa definido como a soma entre lucro líquido, depreciação e amortização \\
\hline V & Vendas (Receita Operacional Líquida $)$ \\
\hline AT & Ativo Total \\
\hline tam & Tamanho da firma, medido pelo logaritmo natural do AT \\
\hline PL & Patrimônio Líquido \\
\hline LO & Lucro Operacional \\
\hline CCL & $\begin{array}{l}\text { Capital Circulante Líquido, definido como a diferença entre o ativo circulante e o } \\
\text { passivo circulante }\end{array}$ \\
\hline$\Delta C C L$ & Variação do CCL= CCL - CCL t- \\
\hline FCL & Fluxo de Caixa Livre $=$ Fluxo de Caixa $-\Delta C C L ~-$ Investimento \\
\hline ELP & Dívida de Longo Prazo, medido pelo passivo exigível em longo prazo \\
\hline PC & Dívida de Curto Prazo, medido pelo passivo circulante \\
\hline D & Dívida Total= ELP + PC \\
\hline CT & Capital Total= PC + ELP + PL \\
\hline ROA & Retorno sobre Ativo $=$ lucro líquido dividido pelo ativo total \\
\hline LL/PL & Retorno sobre Patrimônio Líquido $=$ lucro líquido dividido pelo patrimônio líquido \\
\hline Div & Disponível e investimentos de curto prazo \\
\hline Dividendos $=$ Dividendos pagos por ação $\times$ Quantidade de Ações \\
\hline Q de Tobin $=($ Valor de Mercado + Div $) / A T$ \\
\hline
\end{tabular}


Tabela A.1: Tabela de Correlação entre as variáveis utilizadas no estudo

\begin{tabular}{|c|c|c|c|c|c|c|c|c|c|}
\hline Variáveis & $\mathrm{I} / \mathrm{K}_{\mathrm{t}-1}$ & $\mathrm{FC} / \mathrm{K}_{\mathrm{t}-1}$ & $\mathrm{D} / \mathrm{K}_{\mathrm{t}-1}$ & $\mathrm{~V} / \mathrm{K}_{\mathrm{t}-1}$ & Caixa $/ \mathrm{K}_{\mathrm{t}-1}$ & FCL/V & $\mathrm{LO} / \mathrm{K}_{\mathrm{t}-1}$ & $\mathrm{LL} / \mathrm{PL}$ & ROA \\
\hline $\mathrm{I} / \mathrm{K}_{\mathrm{t}-1}$ & 1 & & & & & & & & \\
\hline $\mathrm{FC} / \mathrm{K}_{\mathrm{t}-1}$ & 0,1198 & 1 & & & & & & & \\
\hline $\mathrm{D} / \mathrm{K}_{\mathrm{t}-1}$ & 0,2159 & 0,1649 & 1 & & & & & & \\
\hline $\mathrm{V} / \mathrm{K}_{\mathrm{t}-1}$ & 0,0960 & 0,3493 & 0,4157 & 1 & & & & & \\
\hline Caixa/K $\mathrm{K}_{\mathrm{t}-1}$ & 0,1637 & 0,4378 & 0,3964 & 0,3696 & 1 & & & & \\
\hline FCL/V & 0,0170 & 0,0841 & 0,0527 & 0,0234 & $-0,0229$ & 1 & & & \\
\hline $\mathrm{LO} / \mathrm{K}_{\mathrm{t}-1}$ & 0,0219 & 0,8102 & 0,0120 & 0,3017 & 0,3056 & 0,0513 & 1 & & \\
\hline $\mathrm{LL} / \mathrm{PL}$ & 0,0393 & 0,4860 & $-0,0003$ & 0,1079 & 0,1252 & 0,1272 & 0,4592 & 1 & \\
\hline ROA & 0,0143 & 0,7075 & $-0,0571$ & 0,1579 & 0,1905 & 0,1279 & 0,6732 & 0,7670 & 1 \\
\hline Pirâmide & 0,0092 & $-0,0532$ & $-0,0762$ & $-0,0783$ & 0,0110 & $-0,0497$ & $-0,0425$ & 0,0166 & 0,0058 \\
\hline $\begin{array}{l}\text { Controle por Acordo } \\
\text { entre Acionistas }\end{array}$ & 0,0082 & 0,0183 & 0,0239 & $-0,0084$ & $-0,0107$ & $-0,0057$ & 0,0235 & 0,0742 & 0,0733 \\
\hline Controle Estatal & $-0,0358$ & $-0,0922$ & $-0,1341$ & $-0,1245$ & $-0,1060$ & $-0,0440$ & $-0,0461$ & $-0,0063$ & $-0,0346$ \\
\hline Controle Estrangeiro & 0,0032 & 0,0337 & $-0,0284$ & $-0,0153$ & $-0,0623$ & 0,0083 & 0,0201 & $-0,0089$ & 0,0119 \\
\hline Controle Familiar & 0,0059 & $-0,0401$ & 0,0566 & 0,0088 & 0,0404 & 0,0445 & $-0,0658$ & $-0,0752$ & $-0,0756$ \\
\hline $\mathrm{CD}$ & 0,0046 & 0,0489 & 0,1830 & 0,1122 & 0,0687 & 0,0406 & 0,0216 & 0,0226 & $-0,0289$ \\
\hline Conselho & 0,0322 & 0,0003 & 0,1627 & 0,1326 & 0,1321 & 0,0214 & $-0,0266$ & $-0,0417$ & $-0,0697$ \\
\hline Diretor & 0,0030 & 0,0552 & 0,1793 & 0,1076 & 0,0702 & 0,0441 & 0,0316 & 0,0243 & $-0,0283$ \\
\hline Variáveis & Pirâmide & $\begin{array}{c}\text { Controle por } \\
\text { Acordo entre } \\
\text { Acionistas }\end{array}$ & & $\begin{array}{c}\text { Controle } \\
\text { Estatal }\end{array}$ & $\begin{array}{l}\text { Controle } \\
\text { Estrangeiro }\end{array}$ & $\begin{array}{l}\text { Controle } \\
\text { Familiar }\end{array}$ & $\mathrm{CD}$ & Conselho & Diretor \\
\hline Pirâmide & 1 & & & & & & & & \\
\hline $\begin{array}{l}\text { Controle por Acordo entre } \\
\text { Acionistas }\end{array}$ & 0,1128 & 1 & & & & & & & \\
\hline Controle Estatal & $-0,2075$ & $-0,0678$ & & 1 & & & & & \\
\hline Controle Estrangeiro & $-0,1042$ & $-0,1104$ & & $-0,1202$ & 1 & & & & \\
\hline Controle Familiar & 0,1437 & $-0,2019$ & & $-0,2197$ & $-0,3576$ & 1 & & & \\
\hline $\mathrm{CD}$ & 0,0141 & $-0,0994$ & & $-0,19$ & $-0,3093$ & 0,4904 & 1 & & \\
\hline Conselho & 0,1512 & $-0,0504$ & & $-0,2754$ & $-0,4366$ & 0,6123 & 0,6784 & 1 & \\
\hline Diretor & 0,0265 & $-0,0939$ & & $-0,1949$ & $-0,3172$ & 0,5029 & 0,975 & 0,6482 & 1 \\
\hline
\end{tabular}


